\title{
The Political Influence of the Military \\ Before and After Democratic Transition: \\ Experiences from Indonesia - An Assessment on Myanmar
}

Benjamin H. Beets

A dissertation submitted to Victoria University of Wellington in partial fulfilment of the requirements for the degree of Master in Strategic Studies

Victoria University of Wellington 


\section{ABSTRACT}

Historically, the Indonesian National Armed Forces (TNI) and Myanmar's Armed Forces (Tatmadaw) held tremendous levels of domestic political influence. Following independence in the 1940s, both countries experienced a short and unstable democratic period. Largely due to the weakness of civilian institutions, and the special place of the TNI and the Tatmadaw in society, both militaries became the most dominant political actors in their respective countries. In 1998, President Suharto's government fell, which instigated a period of political reform whereby the TNI removed itself from the political realm. It would seem as if democratisation has seen the TNI lose significant political clout. However, is it this simple? Does democratisation mean a total loss of political influence for the military?

This paper seeks to understand to what extent the TNI lost political influence in the democratic era and whether similar developments are likely for Myanmar's Tatmadaw. To answer this question, this paper will review literature on influence, democracy and civilmilitary relations in order to produce a thematic framework of indicators that can be used for further analysis on the TNI and the Tatmadaw. Once a framework has been laid, this paper will investigate the Indonesian experience, focusing on pre-democracy (1945-1998), before shifting to see how influential the TNI is in the democratic era (1998-2015). The Tatmadaw's political influence will then be examined in the junta period (1948-2015). Once the Tatmadaw current state is understood, this paper will provide informed judgements on the likely influence of the Tatmadaw in a future democratic Myanmar.

This paper found that in the post-Suharto era, the TNI still retains political influence as a result of its strong standing in Indonesian society, involvement in off-budget income generation, and a strong internal security role, as well as weak civilian institutions. Although the TNI no longer have a dominant role in Indonesia politics, they certain hold a level of political influence in Jakarta. With Myanmar heading toward democratisation, after fifty years of junta rule, will the Tatmadaw follow a similar trajectory? This paper is timely. November 8 , 2015 will see democratic elections take place in Myanmar. The most popular political party, the National League for Democracy, led by democratic icon Aung San Suu Kyi, is likely to do very well in the election. At the same time, Myanmar's 2008 Constitution indirectly bans her from becoming president, provides the Tatmadaw with 25 percent of the seats in parliament and gives the military a veto option, even in the supposedly democratic era. 


\section{ACKNOWLEDGMENTS}

I acknowledge the unwavering support and love of my family. Without their support I would not have been able to pursue this project in its entirety which included many days away in Southeast Asia, and many weekends and weeknights locked away in my office.

Thank you to my supervisors Professor Robert Ayson and Associate Professor David Capie who both provided me with inspiration and invaluable guidance throughout. I also thank my other professors at the Centre for Strategic Studies New Zealand who spent many hours with me discussing core strategic studies theory and its application over the past three years.

I thank Education New Zealand, who awarded me a generous 'Prime Minister's Scholarship for Asia.' This scholarship enabled field research trips to Singapore, Myanmar and Indonesia which greatly increased my cultural understanding of my case studies but also made me more aware of my lack of knowledge of Southeast Asia. Two things I will not forget; the great food and the interesting taxi drivers.

Thank you to all of the analysts, academics, military attachés, officials and friends who provided their valuable time in Singapore, Jakarta, Yogyakarta, Yangon and Naypyidaw, as well as New Zealand and Australia.

Thank you to my peers who provided feedback and support throughout.

I also wish to acknowledge the flexibility and support provided to me throughout this project by my employer.

Although I received significant support, the errors, omissions and blatant mistakes herein are mine alone. 


\section{TABLE OF CONTENTS}

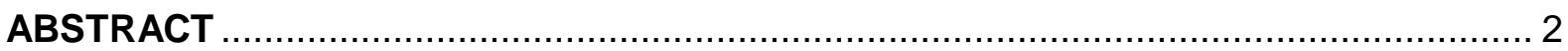

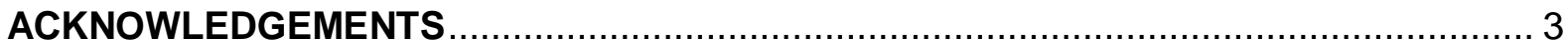

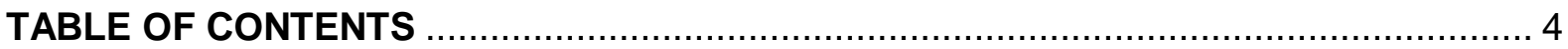

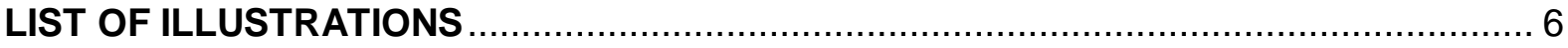

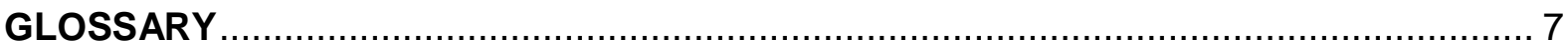

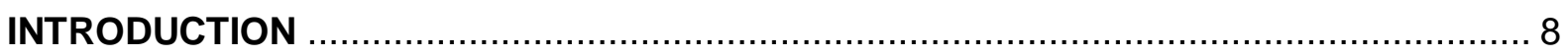

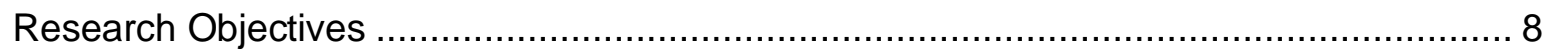

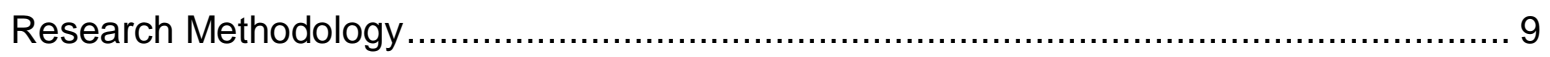

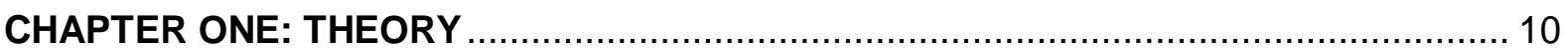

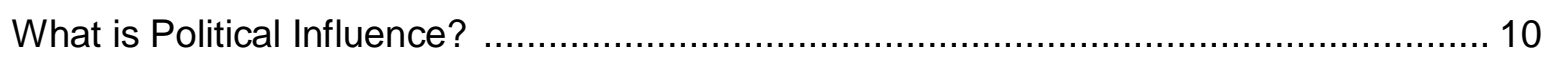

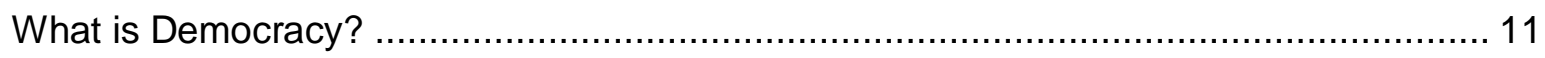

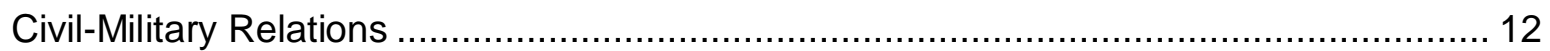

Classical Theory on Civil-Military Relations ...................................................... 13

Recent Theory on Civil-Military Relations ......................................................... 14

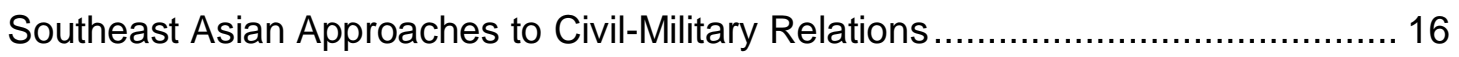

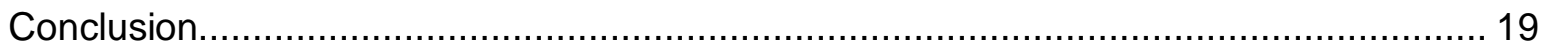

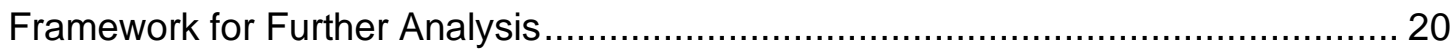

CHAPTER TWO: THE POLITICAL INFLUENCE OF THE INDONESIAN NATIONAL

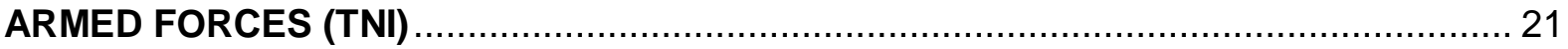

Part One: The Political Influence of the TNI Prior to Democracy ..................................... 23

Part Two: The Political Influence of the TNI in Democratic Indonesia ............................. 31

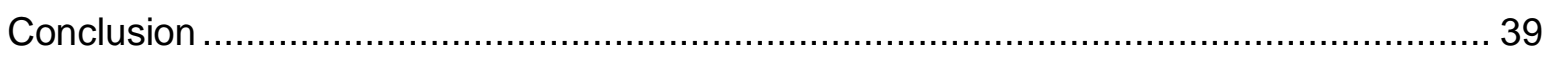

CHAPTER THREE: THE POLITICAL INFLUENCE OF MYANMAR'S ARMED FORCES

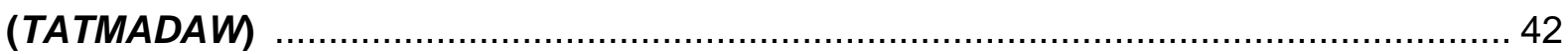

Part One: The Political Influence of the Tatmadaw Prior to Democracy ........................... 45

Part Two: Assessment - The Political Influence of the Tatmadaw in a Democratic

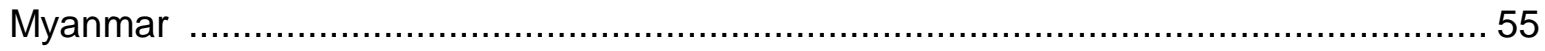

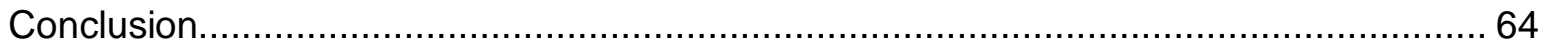

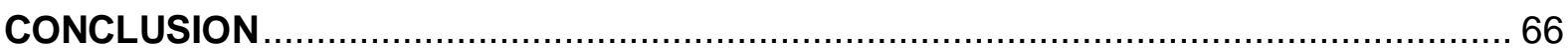

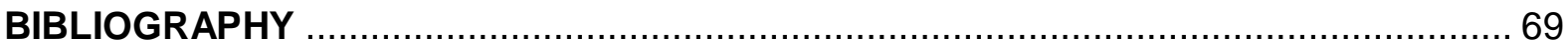


ANNEXES

Annex A: Cone of Plausibility, The Weakness of Civilian Institutions and the Involvement of

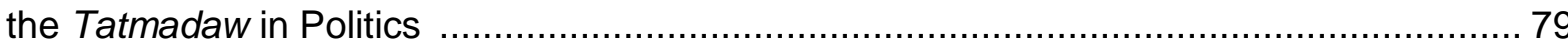

Annex B: Cone of Plausibility, The Internal Security Focus of the Tatmadaw...................... 80

Annex C: Cone of Plausibility, The Tatmadaw's Corporate Interests 


\section{LIST OF ILLUSTRATIONS}

Map 1 - Orientation Map of Southeast Asia ................................................................ 17

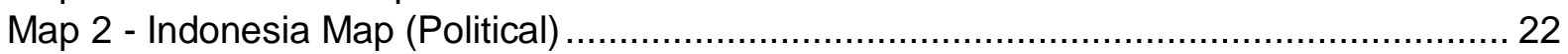

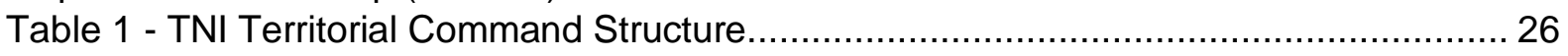

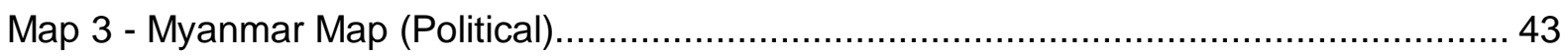

Table 2- Drivers and Assumptions - The Weakness of Civilian Institutions and the Involvement of the Tatmadaw in Politics in a Democratic Myanmar. ................................ 57

Table 3- Drivers and Assumptions - The Internal Security Focus of the Tatmadaw in a

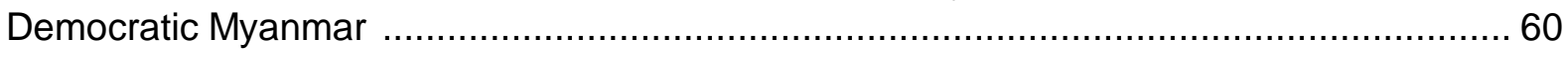

Table 4 - Drivers and Assumptions - The Weakness of Civilian Institutions and the Involvement of the Tatmadaw in Politics in a Democratic Myanmar 


\section{GLOSSARY}

\section{ACRONYMS AND FOREIGN WORDS}

AFC

AFPFL

Amyotha Hluttaw

ASEAN

ASSK

BIA

BRIMOB

BSPP

CIMIC

CMR

Detasemen Khusus 88

GAM

GDP

GOLKAR

IPAC

KNIL

KOSTRAD

KPK

MOOTW

MPR

NATO

NLD

PKI

POLRI

Pyidaungsu Hluttaw

Pyithu Hluttaw

Reformasi

Sangha

SBY

SLORC

SPDC

Tatmadaw

Tentara Nasional Indonesia

US

USD

USDP
Asian Financial Crisis

Anti-Fascist People's Freedom League (Myanmar)

Upper House of Myanmar's Parliament

Association of Southeast Asian Nations

Aung San Suu Kyi

Burmese Independence Army

Korps Brigade Mobil, Police Paramilitary Unit

Burma Socialist Program Party

Civil Military Cooperation

Civil Military Relations

Detachment 88, Police Counterterrorism Unit

Gerakan Aceh Merdeka

Free Aceh Movement

Gross Domestic Product

Partai Golongan Karya

The Party of the Functional Groups

Institute for Policy Analysis of Conflict

Koninklijk Nederlands-Indische Leger

The Royal Dutch East Indies Army

Komando Cadangan Strategis Angkatan Darat

Indonesian Army Reserve Strategic Command

Komisi Pemberantasan Korupsi

Corruption Eradication Commission (Indonesia)

Military Operations Other Than War

Majelis Permusyawaratan Rakyat Republik Indonesia

People's Consultative Assembly (Indonesia)

North Atlantic Treaty Organisation

National League for Democracy (Myanmar)

Indonesian Communist Party

Kepolisian Negra Republik Indonesia

Indonesian National Police

Myanmar's Parliament, both Upper and Lower Houses

Lower House of Myanmar's Parliament

Indonesian Political Reform Period (From 1998)

Buddhist Monastic Order in Myanmar

Susilo Bambang Yudhoyono

State Law and Order Restoration Council

State Peace and Development Council

Myanmar Armed Forces

Tentara Nasional Indonesia

Indonesian National Armed Forces

United States of America

United States Dollar

Union Solidarity and Development Party 


\section{INTRODUCTION}

When an authoritarian regime decides to hand power to the people through free and fair democratic elections, one could assume that the military would remove itself from the political arena. One could also assume that the military, once the most politically influential force in many Southeast Asian countries, would act at the behest of a democratically elected government; not against the government but for it. This dissertation seeks to understand to what extent the Indonesian National Armed Forces (TNI) ${ }^{1}$ lost political influence in the democratic era and whether similar developments are likely for Myanmar's Armed Forces (Tatmadaw). This paper does not assume that Indonesia and Myanmar are directly comparable. However, there are some very bold similarities between the two Southeast Asian nations, especially with regards to the place of the armed forces in society.

This paper will be made up of three chapters. Chapter one will focus on the theories of political influence, democracy and civil-military relations in order to produce a framework for further analysis of the TNI and the Tatmadaw. Chapter Two will analyse the TNI's political role in both the pre-democratic and democratic eras in order to establish the extent to which the TNI lost political influence after 1998, when President Suharto stood down. Chapter Three will analyse the Tatmadaw's political dominance from independence in 1948 until immediately prior to the November 2015 elections. The Second Section of Chapter Three will provide informed judgements about how this issue is likely to develop over the coming years. These informed judgements, referred to as assessments, are required because Myanmar is yet to fully realise democracy. Without such assessments it is impossible to answer the question.

\section{RESEARCH OBJECTIVES}

This paper seeks to answer the following question: to what extent has the TNI lost political influence in the democratic era and are similar developments likely for Myanmar's Tatmadaw? This question has two main parts. The first part focuses on understanding Indonesian civil-military relations. There is a requirement to compare the political influence that the TNI had before democracy and after Suharto stood down in 1998. This comparison will answer the first part of the question. The second part requires an understanding of the Burmese experience to lay the foundations of the issue before making judgements on plausible futures of the Tatmadaw and democracy in Myanmar.

\footnotetext{
${ }^{1}$ The Indonesian military has been renamed several times since it was founded during the Revolution. This paper will refer to the Indonesian military as the TNI, the acronym derived from its full name: Tentara Nasional Indonesia (TNI; Indonesian National Armed Forces).
} 


\section{RESEARCH METHODOLOGY}

This study is based on qualitative analysis of available primary and secondary sources, the findings from which will form the foundation of the argument. Findings from these sources produce the argument. This paper employs an analytical method referred to as the cone of plausibility to help produce informed judgements about Myanmar's future. The cone of plausibility, as well as the significant limits of using any futurist analytical method, will be described in the Myanmar chapter.

Sources were selected with the assistance of contacts in Southeast Asia as well as specialists in New Zealand and Australia. Due to the large selection of available primary and secondary sources, it was felt early on in the research phase that interviews were not required as part of the gathering of research material. However, during field research excursions to Singapore, Indonesia and Myanmar discussions were had with government officials, analysts, academics, defence attachés, economists and ambassadors. These semiformal discussions have supplemented the primary and secondary source analysis. Findings from these discussions were further investigated in the literature, and subsequently referred without linking the idea to the respective meeting. As such, the content of these discussions remains confidential. The field research excursions were funded through a New Zealand Prime Minister's Scholarship for Asia. The field research excursions took place over the following dates in 2015; Singapore 10-24 January, Indonesia 16 May-3 June, and Myanmar 3 June-14 June. Travel has allowed a much richer appreciation of Southeast Asian cultures and local attitudes toward armed forces in society.

There are serious barriers with studying Indonesia and Myanmar, including the limiting effect of different languages and the cultural complexities of both countries. To comprehend this, significant background reading was required. Discussions were had with both Burmese and Indonesians on their views of the topic. This enabled a better appreciation of predispositions that affected earlier understandings of the topics. 


\section{CHAPTER ONE: THEORY}

This chapter will explore existing literature on the military's political influence before and after democratic transition, focusing on Southeast Asia. Much of the theory on the military's political influence is found within the body of literature known as civil-military relations (CMR). Therefore, this chapter will examine CMR, highlighting themes that assist in analysing and describing the political influence of the military. This chapter will explore both classical and recent theory before focusing on Southeast Asian approaches. The chapter will conclude with the provision of a thematic framework of indicators derived from the theory that illustrates the political influence of the military in Southeast Asia. In later chapters, this framework will be used as a tool to investigate the TNI's overall political influence before and after democratic transition in Indonesia and the contemporary political influence of Myanmar's Tatmadaw. Assessments made on the future of Myanmar's CMR will also use this framework. For the purposes of this paper, it is crucial to understand the meaning of two key concepts: political influence and democracy.

\section{WHAT IS POLITICAL INFLUENCE?}

Influence is a concept that is easy to define but difficult to measure. The simplest way to describe influence is the most direct, it is "the ability to get others to act as you intend." However, influence can also be indirect and create unintended second and third order effects. Therefore, influence is having a positive, negative, neutral, intentional or unintentional effect on something be it people, governments, markets, politics, war or academia. This paper is primarily concerned with the influence of the military as it pertains to politics. For the purposes of this paper, influence will be defined as the ability to bring about the political ends one desires through both attractive and coercive means.

There are many ways militaries and military officers can influence domestic politics other than the coercive use of force. This can include lobbying civilian politicians, shaping public opinion and participating in civil society organisations or think tanks. ${ }^{3}$ However, military organisations have the added ability to use physical violence to conduct coercive actions against a civilian population or against governments. Coercive force is rarely considered an appropriate or legitimate method of domestic influence. Coercion, regardless of its illegitimacy, remains one form of political influence available to the military. The fact is that the military is the national instrument charged with conducting organised violence in defence of the state. As the law of the instrument notes "if the only tool you have is a

\footnotetext{
${ }^{2}$ Edward C. Banfield, Political Influence (New Brunswick: Transaction Publishers, 2003), xxii.

${ }^{3}$ Marcus Mietzner, Military Politics, Islam, and the State of Indonesia: From Turbulent Transition to Democratic Consolidation (Singapore: Institute of Southeast Asian Studies, 2009), 8.
} 
hammer, you tend to treat everything as a nail." ${ }^{4}$ As such, the military may have a predisposition toward the use of force as an influencing tool.

\section{WHAT IS DEMOCRACY?}

Democracy is an emotive word which means many different things to many different people. Joseph Schumpeter argued that the definition of democracy had been made into a utopian or idealistic idea. ${ }^{5}$ Schumpeter was referring to the point that theory on democracy at that time (1940s) defined democracy using its supposed source (the will of the people) and its idealised purpose (the common good). ${ }^{6}$ Schumpeter argued that there was "another theory of democracy." "The democratic method [...]" Schumpeter argued, "[...] is that institutional arrangement for arriving at political decisions in which individuals acquire the power to decide by means of a competitive struggle for the people's vote." 8 This paper will follow Schumpeter's argument by using a definition of democracy coined by Samuel $P$. Huntington. Huntington's definition regarded a "[...] political system as democratic to the extent that it's most powerful collective decision makers are selected through fair, honest and periodic elections in which candidates freely compete for votes and in which virtually all of the adult population is eligible to vote."

As well as free and fair elections, democracy has other connotations. Democratic societies often pride themselves on human rights, including the right to peaceful protest, free speech and the right to a fair legal trial, as well as others. Empirical research has concluded that there is a positive relationship between democracy and human rights. ${ }^{10}$ Scholars found that not only was there a positive relationship between the two concepts, but human rights actually underpinned democracy itself. ${ }^{11}$ Without a baseline of human rights, democracy can not effectively function.

Democratisation is the process in which a country becomes democratic as opposed to another system of governance. The country could have been an authoritarian regime, meaning that the vast majority of the people could not vote for their political leadership. Democratisation is not a simple process for a country to advance through. Many Western states took hundreds of years to advance along the democratic spectrum before becoming

\footnotetext{
${ }^{4}$ Abraham H. Maslow, Psychology of Science: A Reconnaissance (Oxford: Gateway Editions, 1966).

${ }^{5}$ Samuel P. Huntington, The Third Wave: Democratization in the Late Twentieth Century (Norman: University of Oklahoma Press, 1993), 6.

${ }^{6}$ Ibid.

7 lbid.

8 Ibid.

${ }^{9}$ Ibid.

${ }^{10}$ Kirsten Haack, The United Nations Democracy Agenda: A Conceptual History (Manchester: Manchester University Press, 2011), 61.

${ }^{11}$ Ibid.
} 
consolidated democracies. As a democratic country evolves, it advances from democratic transition into a phase of democracy called 'consolidation.' Once a transitional democracy becomes a consolidated democracy, it is unlikely it will revert to authoritarianism. ${ }^{12}$ Examples of countries that can be regarded as consolidated democracies include the United Kingdom, India and France. ${ }^{13}$ Though Mexico and South Africa are accepted as examples of transitional democracies, they are not seen to be consolidated democracies. ${ }^{14}$ While a country is in its democratic transition, the military may remain a strong political actor due to the weakness of the civilian institutions. ${ }^{15}$ To function effectively as a democracy the country requires a reasonable standard of security in order to facilitate a peaceful transfer of power through an electoral system. It is widely accepted that for a democracy to flourish, the military must accept that it is subordinate and subservient to the democratically elected government. ${ }^{16}$ It is possible for a transitional democracy to revert back to an authoritarian regime; examples include Iran in 1953 and more recently Fiji in 2006. ${ }^{17}$ In both cases the democratically elected government was overthrown by elements of the military through successful coups. This illustrates how influential the military typically is in any transitional democracy, which is an issue at the nexus of CMR.

\title{
CIVIL-MILITARY RELATIONS
}

\author{
"War is too important a matter to be left to the military." 18 \\ Georges Clemenceau
}

"Peace is too important to be left in the hands of civilians."19

Admiral Thomas B. Hayward

CMR is a field of study that covers not only the relationship between the armed forces and the state, but also its relationship with the wider political scene and civil society. ${ }^{20}$

\footnotetext{
${ }^{12}$ Gerard Alexander, The Sources of Democratic Consolidation (Ithaca: Cornell University, 2002), 59.

${ }^{13}$ Mark Kesselman, Joel Krieger and William A. Joseph, Introduction to Comparative Politics: Brief Edition (Boston: Houghton Mifflin Harcourt, 2009), 39, 99 and 153.

14 Ibid., 263 and 313.

${ }^{15}$ Muthiah Alagappa, Coercion and Governance: The Declining Role of the Military in Asia (Stanford: Stanford University Press, 2001), 452.

${ }^{16}$ Kesselman, Krieger and. Joseph, Introduction to Comparative Politics: Brief Edition, 21.

${ }^{17}$ Ironically it was a democratic country, the US, that assisted the Iranian Shah to overthrow the democratically elected government in Tehran; Andrew Scott Cooper, The Oil Kings: How the U.S., Iran, and Saudi Arabia Changed the Balance of Power in the Middle East (New York: Simon \& Schuster, 2011), 22-23.

${ }^{18}$ Bong Lee, The Unfinished War: Korea, (New York: Algora Publishing, 2013), 92.

${ }^{19}$ General A.S. Collins, Jr, USA (Ret.), “...On Land,” Bulletin of the Atomic Scientists, May (1979): 33.

${ }^{20}$ Alagappa, Coercion and Governance: The Declining Role of the Military in Asia, 4.
} 
CMR includes the national level interface between the military and various branches of government. CMR does not include the operational relationship between the military and civil agencies, like police, intelligence or disaster-relief, which is referred to as civil-military affairs or civil-military cooperation (CIMIC). ${ }^{21}$ As countries have different political systems, ranging from democratic to totalitarian, it is difficult to apply a single model of CMR across all societies.

The predominant discussion of CMR includes some normative bias with regards to preference toward civilian control of armed forces, as opposed to military dominance of politics. ${ }^{22}$ For the purpose of this paper it is useful to deconstruct this bias as it can be misleading. For instance, the bias toward civilian control assumes the word 'military' has a similar connotation across countries; which is not the case. Militaries around the world hold different perceptions of their place in society. Some militaries brand themselves as defence forces. ${ }^{23}$ Other militaries describe themselves as armed forces and others see themselves as belonging to the people or a monarch. ${ }^{24}$ Some militaries were established centuries ago and have become what is referred to now as professional armed forces. ${ }^{25}$ Other militaries are much younger, evolving from militia groups or established in an ad hoc manner during anti-colonial or revolutionary periods. ${ }^{26}$ Other groups who view themselves as a military force may not even officially represent an internationally recognised country; such as the Provisional Irish Republican Army, the Kachin Independence Army, and the People's Defence Force of the Kurdistan Workers' Party.

\section{CLASSICAL THEORY ON CIVIL-MILITARY RELATIONS}

Much of the literature on CMR discusses mechanisms to deal with the subject's predominant assumption; that it is preferable to have civilian control of the military. This clash is an age old challenge to the governance of human societies and is an issue that many have struggled with. Sun Tzu and Carl von Clausewitz argued long ago that the military was a subordinate function of the state. Sun Tzu argued that: "normally, when the

\footnotetext{
${ }^{21}$ North Atlantic Treaty Organisation (NATO), Allied Joint Publication 9: NATO Civil-Military Cooperation Doctrine (Brussels: NATO, 2003), 1-1.

${ }^{22}$ Huntington, Janowitz, Clausewitz and Sun Tzu are all examples of this.

${ }^{23}$ For example, Israel, Australia, Ireland, South Africa and Timor-Leste all refer to their respective militaries as defence forces. Japan goes a step further in emphasising its military's defensive nature with the Japanese SelfDefense Force.

${ }^{24}$ Examples of countries who brand their militaries as armed forces include Brazil, Indonesia, Spain and Sri Lanka. Vietnam, China, Laos, Algeria, North Korea and South Sudan all use the word 'people' in the title of their respective militaries. Tonga and the United Kingdom's armed forces use the word majesty in the official name. For comprehensive analysis on the world's militaries, including their official names, see the latest Military Balance, published annually by the International Institute of Strategic Studies.

${ }^{25}$ For example, Her Majesty's Armed Forces of Great Britain and Northern Ireland.

${ }^{26}$ For example, the People's Liberation Army in China, the Indonesian National Armed Forces, the Timor-Leste Defence Force
} 
army is employed, the general first receives his commands from the sovereign." ${ }^{27}$ Clausewitz noted that: "war is simply a continuation of political intercourse, with the addition of other means." ${ }^{28}$ On government oversight of military activities Clausewitz noted "...the assertion that a major military development, or plan for one, should be a matter for purely military opinion is unacceptable and can be damaging." ${ }^{29}$ In this piece, Clausewitz was explaining the necessity of separating the soldier from politics and the equally important point that politicians require an understanding of military matters. This was Clausewitz's theoretical method of limiting the political influence of the military by decreasing its participation in the political arena. Thus when military personnel are involved in the administration of a political system, the armed forces likely have an increased ability to influence politics.

\section{RECENT THEORY ON CIVIL-MILITARY RELATIONS}

Samuel P. Huntington's Soldier and the State, published in 1957, argues that the most productive way of dealing with the civil-military conflict is to exert "[...] objective civilian control [...]" over the armed forces by professionalising them. ${ }^{30}$ Huntington's theory argues that there should be a clear delineation of responsibility between the military officer and the politician. ${ }^{31}$ It was Huntington's view that politicians should not get actively involved in military matters and military officers should not get involved in political concerns. ${ }^{32}$ Huntington argues that in the United States of America (US), military officers are endowed, through specialist education in the management of violence." ${ }^{33}$ Huntington argues that these so-called professional officers have a "calling to serve the public interest." ${ }^{34}$ Writing in the early 1970's, Bengt Abrahamsson noted that for Huntington, professionalism also meant that the military had to be politically neutral. ${ }^{35}$ In simple terms, Huntington argues that a military is only professional when it serves the public interest; in contrast to other militaries that serve

\footnotetext{
${ }^{27}$ Sun Tzu, The Art of War, trans. Samuel B. Griffith (London: Duncan Baird Publishers, 2005), 155.

${ }^{28}$ Carl von Clausewitz, On War (Princeton: Princeton University Press, 1976), 605.

${ }^{29}$ Ibid., 607-608.

${ }^{30}$ Samuel P. Huntington, The Soldier and the State: The Theory and Politics of Civil-Military Relations (London: Oxford University Press, 1959) quoted in James Burk, "Theories of Democratic Civil-Military Relations," Armed Forces \& Society, Vol. 29, No.1 Fall 2002, 9.

31 Ibid.

${ }^{32}$ Christopher P. Gibson, Securing the State: Reforming the National Security Decision-Making Process at the Civil-Military Nexus (Aldershot: Ashgate Publishing, 2008), 73.

${ }^{33}$ Susan M. Browne "War-Making and U.S. State Formation: Mobilization, Demobilization, and the Inherent Ambiguities of Federalism" in Irregular Armed Forces and their Role in Politics and State Formation, eds. Diane E. Davis and Anthony W. Pereira (New York: Cambridge University Press, 2003), 233.

${ }^{34}$ Huntington, The Soldier and the State: The Theory and Politics of Civil-Military Relations (London: Oxford University Press, 1959), 9.

${ }^{35}$ Bengt Abrahamsson, Military Professionalization and Political Power (Beverly Hills, CA: Sage Publications, 1972), 159; quoted in Thomas C. Bruneau "Impediments to Conceptualizing Civil-Military Relations." quoted in The Routledge Handbook of Civil-Military Relations, eds. Thomas C. Bruneau and Florina Cristiana Matei (New York: Routledge, 2013), 16.
} 
themselves or the interest of their masters. Thus, Huntington's argument assumes that a military can only be professional when it serves a democratically elected government which would allow the people's interests to dictate the conduct of the military, through their elected leadership. By making the military subservient to the democratically elected government, the political influence of the military is directly limited. This shows how civil control of the military is "intricately" linked to democratic rule. ${ }^{36}$ As such, understanding the constitutional civilmilitary dynamic of a country is of vital importance to understanding the political influence of a military in any country. Huntington's thesis is still viewed by many as one of the most important pieces of work on CMR of late. ${ }^{37}$

In 1960, Morris Jonowitz published Professional Soldier, another seminal piece of CMR literature..$^{38}$ Jonowitz's argument follows on from Huntington's in that it also focuses on professionalism within the officer corps as the most appropriate way of providing oversight of the armed forces. The argument provides another solution to the inherent issue of CMR; the management of power vested in the armed forces and ensuring that power is not abused. Under Jonowitz's model, which blurred civilian and military responsibilities, civilian leaders would be required to become familiar with military thinking. ${ }^{39}$ This would allow civilians to make informed decisions about national security matters without relying solely on military commanders. This would in turn limit the political influence of the military overall. Military leaders, in Jonowitz's argument, would be required to contribute to military matters in the political sphere which is similar to the way Clausewitz discussed his thoughts about civilians being included in the military decision-making process. ${ }^{40}$ Janowitz's argument embraced civilian participation in military matters, including participation of citizen-soldiers in national defence. This chain of thought argues that "when citizens serve as soldiers to defend the republic, the interests of the military and the interest of the state overlap, and there is less need to fear a military challenge to the Republic." ${ }^{41}$ This is a popular approach to CMR thinking in the developing world where many militaries were established by the 'people' during revolutionary or anti-colonial times, including in Indonesia and Myanmar. These

\footnotetext{
${ }^{36}$ Aurel Croissant, David Kuehn and Phillip Lorenz, Palgrave Macmillan Democratization and Civilian Control in Asia (Houndmills: Palgrave Macmillan, 2013).

${ }^{37}$ Peter D. Feaver, Armed Servants: Agency, Oversight, and Civil-Military Relations (Cambridge: Harvard University Press, 2003), 7; quoted in Thomas C. Bruneau, "Impediments to Conceptualizing Civil-Military Relations." in The Routledge Handbook of Civil-Military Relations, eds. Thomas C. Bruneau and Florina Cristiana Matei (New York: Routledge, 2013), 16.

${ }^{38}$ Morris Jonowitz, The Professional Soldier: A Social and Political Portrait (New York: The Free Press, 1971).

${ }^{39}$ Gibson, Securing the State: Reforming the National Security Decision-Making Process at the Civil-Military Nexus, 73.

${ }^{40}$ Ibid.; Carl von Clausewitz, On War, trans. Michael Howard and Peter Paret (Princeton: Princeton University Press, 1976), 607-608.

${ }^{41}$ Burk, "Theories of Democratic CMR." 11 .
} 
militaries often view themselves as guardians of the state and of the people. Thus, it is essential to understand the historical context of a nation's civil-military dynamic.

\section{SOUTHEAST ASIAN APPROACHES TO CIVIL-MILITARY RELATIONS}

The theories presented by Huntington and Janowitz are naturally products of their Western origin. As such, they are useful but not entirely appropriate when analysing Southeast Asian CMR. This section will focus on exploring specifically Southeast Asian CMR literature in order to understand key themes and trends that assist in grasping the decline and growth of the military's political influence in Southeast Asia. This section will explore two significant edited volumes on Asian CMR; Muthiah Alagappa's Coercion and Governance and Marcus Mietzner's Political Resurgence of the Military in Southeast Asia. ${ }^{42}$ These two edited volumes sufficiently represent the literature on Southeast Asian CMR as they both include chapters on Indonesia, Myanmar, the Philippines, Singapore, Thailand and Vietnam from highly-regarded scholars. ${ }^{43}$ Alagappa also includes a chapter on Malaysia and Mietzner's volume incorporates a chapter on Timor-Leste.

Alagappa and Mietzner have competing arguments about the trends of Southeast Asian CMR and have different approaches in explaining the indicators that illustrate the political influence of the military. Alagappa focuses on the use of coercion by a military, which he argues increases the political influence of the armed forces, albeit in an illegitimate way. ${ }^{44}$ Mietzner argues that the most important way militaries can gain influence is by becoming involved in the political institutions of the state, when civilian authorities are weak. ${ }^{45}$ Alagappa notes that in 1950 civilian supremacy over the military was the dominant model of Asian CMR. ${ }^{46}$ Conversely, from 1958, through the 1960 s and 1970 s, militaries in much of Asia became the dominant political actor. ${ }^{47}$ Alagappa argues that since 1986 the political influence of the military has been in decline, hence the full title of his book; Coercion and Governance: The Declining Political Role of the Military in Asia. ${ }^{48}$ Writing a decade later, Mietzner argues that the current trend is a Political Resurgence of the Military in Southeast Asia, also the title of his edited volume.

\footnotetext{
${ }^{42}$ Marcus Mietzner, The Political Resurgence of the Military in Southeast Asia (Abingdon: Routledge, 2011); Muthiah Alagappa, Coercion and Governance: The Declining Role of the Military in Asia (Stanford: Stanford University Press, 2001).

${ }^{43}$ Alagappa's is not limited to Southeast Asia and uses other Asian case studies. However, his findings can be taken as being appropriate for specifically Southeast Asia. Alagappa also includes seven chapters on Southeast Asian cases. Mietzner's volume is solely Southeast Asian related.

${ }^{44}$ Alagappa, Coercion and Governance: The Declining Role of the Military in Asia, xviii.

${ }^{45}$ Mietzner, The Political Resurgence of the Military in Southeast Asia , 4.

${ }^{46}$ Alagappa, Coercion and Governance: The Declining Role of the Military in Asia, 433.

${ }^{47}$ Ibid.

${ }^{48}$ Ibid., Xv.
} 


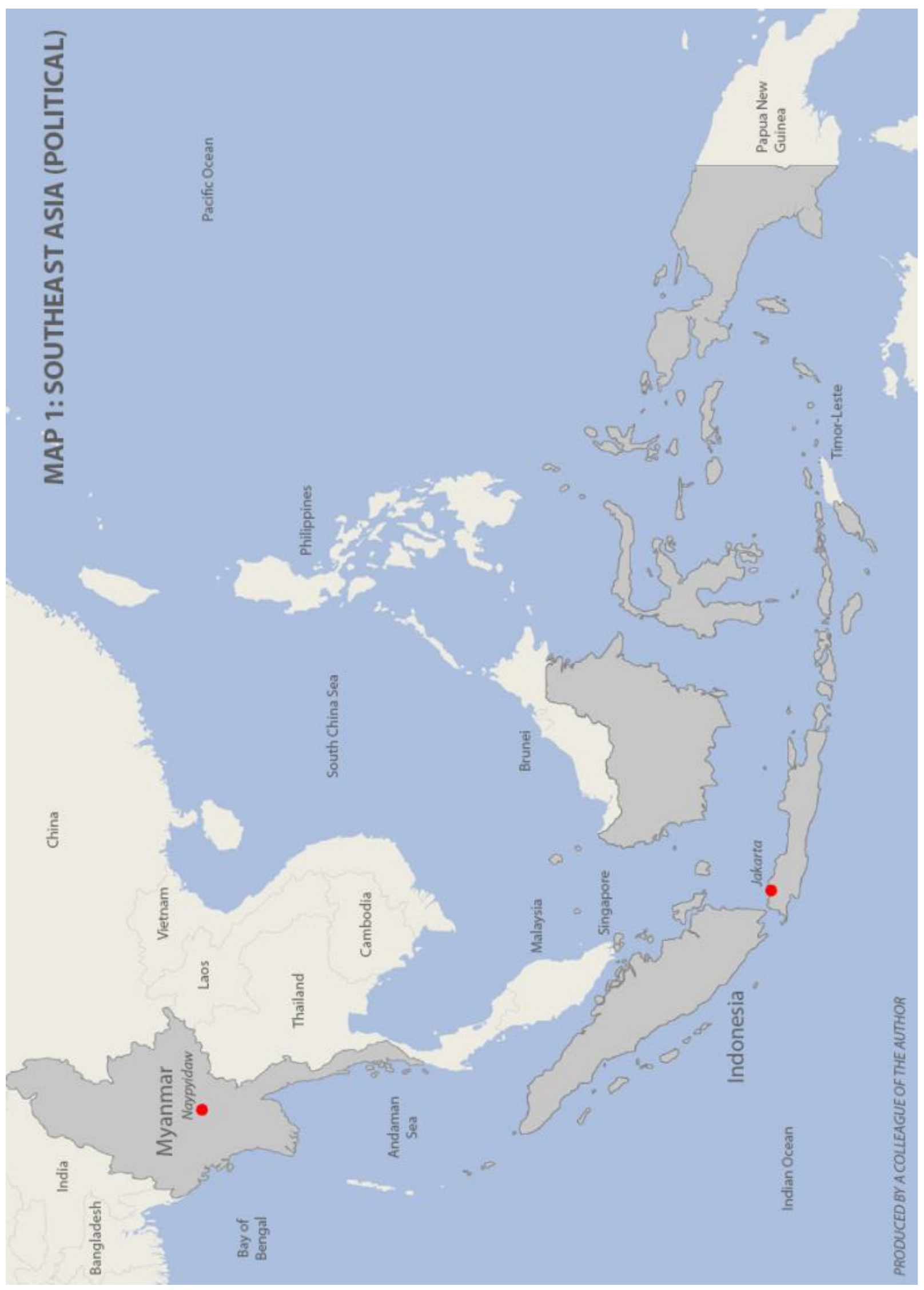


Alagappa and Mietzner agree that the weakness of civilian institutions provides an opportunity for the military to increase its political influence. ${ }^{49}$ Conversantly, strong civilian systems limit the political influence of the military. ${ }^{50}$ Alagappa argues that the weakness of civilian government institutions allows the military to fill the political void and gain influence..$^{51}$ Discussing the military's political rise from 1958, Alagappa notes that many newly formed democratic states could not "...cope with the political, social, and economic mobilization and demands unleashed by independence and a democratic system of government. ${ }^{.52}$ The central argument of Mietzner's book is that failures of civilian governments provide entry points for military intervention into politics, whereby stable civilian polities are able to keep the armed forces at bay. ${ }^{53}$ For Mietzner, the most important way militaries can gain influence is by becoming involved in political institutions of the state. ${ }^{54}$ Although it may seem obvious that when a military is directly involved in the political institutions of the state it is politically influential, this point is nonetheless important to note. This is one of the most important variables to understand in the CMR of any Southeast Asian nation, especially during the early phases of democratic transition when the civilian institutions are new.

Alagappa makes the point that the military will likely assume a greater interest in the corporate world if its governance role is expanded, which subsequently expands the political influence of the military further. ${ }^{55}$ This occurred in Indonesia after 1958, and Myanmar after $1962 .{ }^{56}$ Mietzner agrees that economic involvement is an important method for the military to gain political influence. By becoming involved with the economy the military can limit the influence of civilian institutions by raising off-budget funds giving the military more autonomy from the civilian government. ${ }^{57}$ It is generally accepted that economic activity by the armed forces undermines key principles of democratic CMR, as it allows the military to plan independent operations funded out of its unofficial budget and thus bypass the state's civilian control. ${ }^{58}$ This would decrease the influence any government would have over the military and increase the military's autonomy.

Central to Alagappa's overall argument is the concept of coercion. ${ }^{59}$ Alagappa argues that coercion and political legitimacy are negatively correlated; "the prominence of coercion

\footnotetext{
${ }^{49}$ Alagappa, Coercion and Governance: The Declining Role of the Military in Asia, 452; Mietzner, The Political Resurgence of the Military in Southeast Asia , 2-3.

${ }^{50}$ Ibid., 14.

${ }^{51}$ Alagappa, Coercion and Governance: The Declining Role of the Military in Asia, 452.

52 Ibid.

${ }^{53}$ Mietzner, The Political Resurgence of the Military in Southeast Asia , 2-3.

${ }^{54}$ Ibid., 4.

${ }^{55}$ Alagappa, Coercion and Governance: The Declining Role of the Military in Asia, 451-452.

${ }^{56}$ Ibid., 451.

${ }^{57}$ Mietzner, The Political Resurgence of the Military in Southeast Asia , 7.

${ }^{58} \mathrm{Ibid}$.

${ }^{59}$ Alagappa, Coercion and Governance: The Declining Role of the Military in Asia, xviii.
} 
in securing loyalty and obedience from citizens of the state is a direct reflection of the weakness of the political legitimacy of the nation-state and the government." ${ }^{\text {"S0 }}$ Simply put, a nation-state that relies on coercion to govern will remain 'politically illegitimate' in the eyes of its citizenry. What does this mean for Asian countries with significant domestic security concerns, such as the Philippines, Thailand, Cambodia, Indonesia and Myanmar? Alagappa's argument notes that there is a direct correlation between a country's use of military force for internal security and that military's overall political power and influence. ${ }^{61}$ Therefore, countries that employ their respective militaries to quell internal security threats have politically influential militaries; countries that do this use coercion to govern. These governments, Alagappa argues, lack domestic political legitimacy as a direct result of their coercive behaviour interfering in political affairs. ${ }^{62}$ If the premise of democratic CMR is to have a non-politically orientated military, one could conclude that it is inherently undemocratic to have the military significantly involved in domestic security. Therefore, Alagappa's argument that there is a correlation between a country's use of military force for internal security and that military's overall political influence has real consequences. ${ }^{63}$ If a military is seriously involved in internal security in a democratic country, its democratic CMR are likely strained.

\section{CONCLUSION OF CHAPTER ONE}

This chapter has explored existing literature relevant to the military's political influence before and after democratic transition, focusing on Southeast Asia. Political influence was defined as the ability to get others to act as one intends in the political realm through both passive and coercive means. Democracy was defined as the process of electing the leadership of a state through free and fair elections. The assessment of democratisation found that the military will likely remain a strong political actor during transition due to the weakness of civilian institutions. However, for democracy to flourish the military must accept civilian supremacy. ${ }^{64}$ Much of the literature on CMR discusses mechanisms to deal with the subject's inherent assumption; that it is preferable to have civil control of the armed forces. Where Alagappa focuses on coercion, Mietzner highlights the weakness of civilian institutions as the most important method for a military to gain political influence in Southeast Asia. When the military is economically engaged, it can limit the influence of civilian institutions by raising off-budget funds making the military more

\footnotetext{
${ }^{60}$ Alagappa, Coercion and Governance: The Declining Role of the Military in Asia, 498.

61 Ibid.

62 lbid., 5.

63 Ibid., 498.

${ }^{64}$ Kesselman, Krieger and Joseph, Introduction to Comparative Politics: Brief Edition, 21.
} 
autonomous from the civilian government. The culminating argument of both volumes is that the weakness of civilian institutions provides the opportunity for the military to increase its political influence. ${ }^{65}$ Therefore, Southeast Asian countries with weak civilian institutions will likely have strong politically orientated militaries, both before and after democratic transition. For a Southeast Asian democracy to consolidate, the civilian institutions of the state must be strengthened forcing the military's political influence to dwindle.

\section{FRAMEWORK FOR FURTHER ANALYSIS}

The framework for further analysis is made up of three themes, each of which explain how militaries in Southeast Asia can increase their political influence. The following three themes make up the framework; 1) the weakness of civilian institutions and the involvement of the military in political institutions, 2) the military's internal security role, 3) the military's corporate interests. These three themes will be used to illustrate the political influence of the TNI before and after democratic transition in Indonesia and the current level of political influence of the Tatmadaw in Myanmar. The same framework will then be used to assess the likely political influence of the Tatmadaw in a future democratic Myanmar.

${ }^{65}$ Alagappa, Coercion and Governance: The Declining Role of the Military in Asia, 2-3. 


\section{CHAPTER TWO: THE POLITICAL INFLUENCE OF THE TNI}

Situated at the strategically important cross-roads of Indo-Pacific trade routes, Indonesia is a complex country made up of over 17,500 islands over an area of approximately two million square kilometres. ${ }^{66}$ The country straddles the equator from the Indian Ocean in the west, through the Java, Banda and Timor Seas, and into the Pacific Ocean in the east (See Map 2). Indonesia's 253 million people come from diverse ethnic groups, including Javanese, Sundanese, Malay, Batak, Madurese, and the Minangkabau, as well as many other smaller groups. ${ }^{67}$ Although Bahasa Indonesia is the official language and is spoken by much of the population, there are some 700 other languages in use in Indonesia.

This chapter seeks to answer a core question of this paper; to what extent has the TNI lost political influence in the democratic era? To answer this question, this chapter will be made up of two sections. The first section will discuss the level of the TNl's political influence from when it was founded in 1945 until 1998, when President Suharto ceded power to his deputy, Bacharuddin Jusuf Habibie. The second section will define what the political influence of the military looks like in the democratic era of Indonesian politics. A comparison of the pre and post-democracy findings will answer this aspect of the core question. Both parts of this chapter will be made up of three sections each representing one of the aspects of the framework derived from the core findings of the theory chapter.

\footnotetext{
66 “Indonesia," Central Intelligence Agency World Fact Book, accessed September 23, 2015, www.cia.gov/library/publications/the-world-factbook/geos/id.html.

${ }^{67}$ For an in-depth discussion on Indonesia's socio-cultural complexities and geography see Elizabeth Pisani, Indonesia Etc: Exploring the Improbable Nation (London: Granta, 2013).
} 


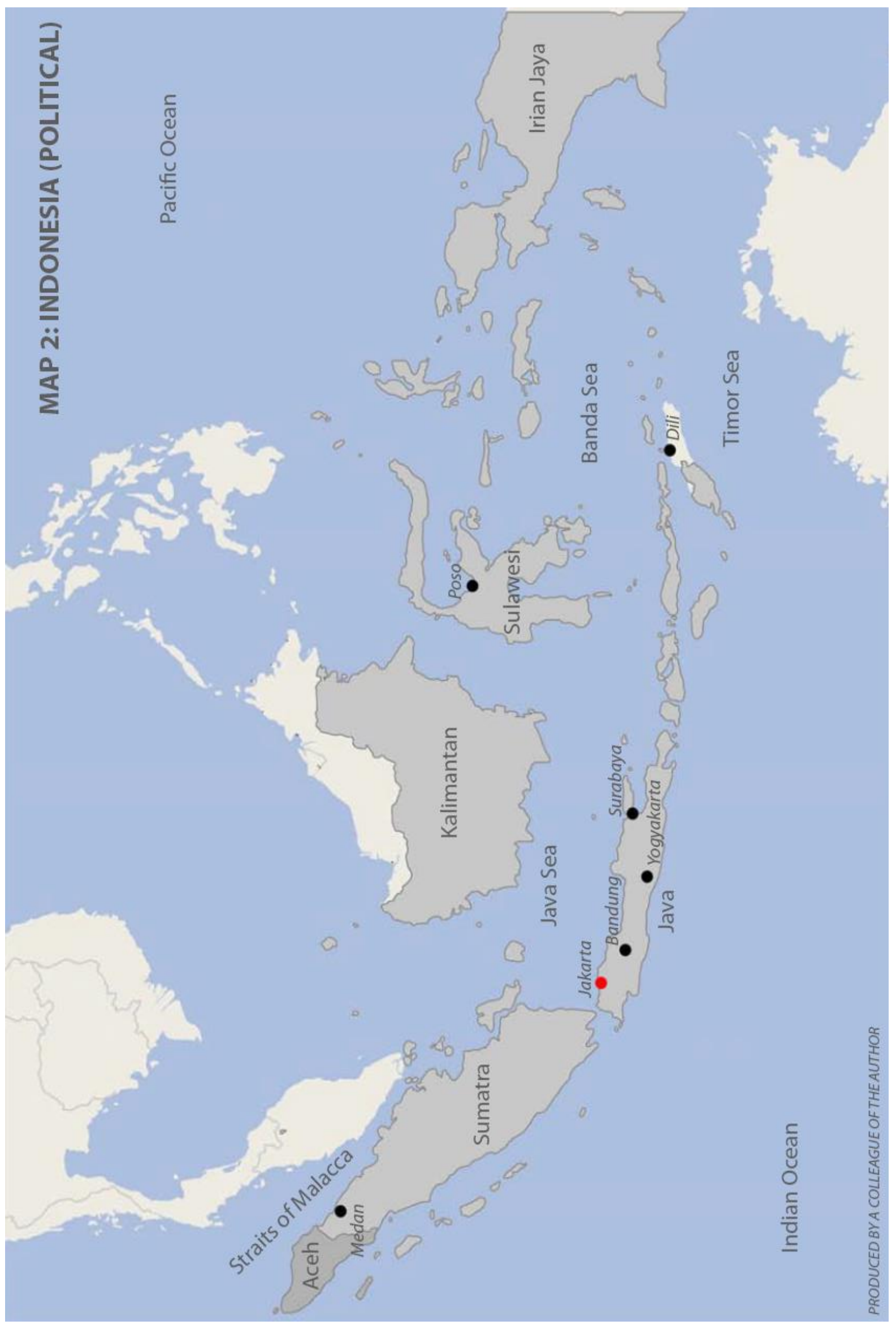




\section{PART ONE:}

\section{THE POLITICAL INFLUENCE OF THE TNI PRIOR TO DEMOCRACY}

This section seeks to understand the extent of the TNI's political influence prior to democracy and will form an argument based around the framework derived from the theory chapter. Three sections will be organised chronologically starting from the Indonesian Revolution in the mid 1940s and ending with Suharto's downfall in 1998. The first section will show how the TNI entered the political realm during the Revolution and subsequent early period of democracy as a result of the weakness of the civilian institutions of that era. The second section will illustrate the extent of the TNl's internal security role, especially with regards to counterinsurgency campaigns against Dar al-Islam and the occupation of East Timor. The third section will argue that the TNI's corporate interests allowed it to create off budget funding which enabled a level of autonomy, thus increasing its overall influence.

\section{THE WEAKNESS OF CIVILIAN INSTITUTIONS AND THE SUBSEQUENT INVOLVEMENT OF THE TNI IN POLITICS PRIOR TO DEMOCRACY}

Speaking to Bilveer Singh in 1998, President Habibie explained that following the Indonesian Revolution (1945-1949), the TNI "[...] was the most organised and most disciplined force in the [political] court, then dominated by weak and divided civilian leaders." 68 This section seeks to understand the weakness of civilian institutions and the involvement of the TNI in political institutions prior to democratisation. The passage will argue that prior to democracy, while civilian institutions remained weak, the TNI was the most dominant actor in Indonesian politics, either directly or indirectly through its political party, GOLKAR. This enabled the TNI to become twined to various aspects of political life, including civilian institutions and political parties.

The TNI acquired its political orientation from its inception, during the Revolution. ${ }^{69}$ Indonesian politicians of that era failed to negotiate a diplomatic solution, whereas the TNI was successful in militarily defeating the Dutch who had returned to 'their' colony following the defeat of the Japanese. ${ }^{70}$ Indonesian politics in the early 1950 s were democratic.

\footnotetext{
${ }^{68}$ President B. J. Habibie, interview with Bilveer Singh on October 3, 1998, quoted in Biveer Singh, Civil-Military Relations in Democratising Indonesia: The Potentials and Limits to Change, Canberra Papers on Strategy and Defence No. 141 (Canberra: Australian National University, 2001), 150.

${ }^{69}$ Harold Crouch, The Army and Politics in Indonesia (Singapore: Equinox, 2007), 22.

${ }^{70}$ Marcus Mietzner, Military Politics, Islam, and the State in Indonesia (Singapore: Institute of Southeast Asian Studies, 2009), 38.
} 
However, the situation remained fragile. ${ }^{71}$ This democratic period saw seventeen different cabinets formed between 1945 and $1957 .{ }^{72}$ A Prime Minister effectively ran the country while Sukarno remained a figure-head President. ${ }^{73}$ Although there was some limited fragmentation within the TNI, namely with Islamic fundamentalists, the organisation maintained a strong central leadership framework which enabled the military to be a unified political force. The weakness of the democratic system of the early 1950's led President Sukarno to declare his Guided Democracy, whereby he lost his figure head role and effectively become the leader of Indonesia. $^{74}$

During the Guided Democracy, Sukarno cancelled elections, banned his opponents and distributed parliamentary seats to the country's so-called "functional groups" which included the $\mathrm{TNI}^{75}$ Sukarno became an increasingly authoritarian leader while the TNI accepted its Middle Way doctrine whereby it would not seek to dominate politics but would not remove itself from the political arena. ${ }^{76}$ This power sharing arrangement was sufficient for the TNI's political desires at the time until the Indonesian Communist Party (Partai Komunis Indonesia: PKI) became increasingly influential.

In the early 1960s the PKI was the TNI's main rival for political dominance. There was a triangle power relationship formed by the TNI, the PKI and Sukarno. ${ }^{77}$ Sukarno had allied himself with the PKI which resulted in the TNI feeling politically threatened. ${ }^{78}$ With Indonesian confrontation in Malayan Borneo (The Indonesian Confrontation: Konfrontasi), the communists' influence over Sukarno had become uncomfortable for the TNI. On 30 September and October 1 1965, six TNI generals were killed by the 30 September Movement, a group linked to the PKI. ${ }^{79}$ Sukarno allowed the Indonesian Army's Strategic Reserve (Komando Cadangan Strategis Angkatan Darat: KOSTRAD) Commander, Major General Suharto, to restore calm in Jakarta through martial law. ${ }^{80}$ The PKI was made illegal and the TNI resorted to the killing of between 200,000 and 1.5 million PKI party activists and

\footnotetext{
71 Jongseok Woo, Security Challenges and Military Politics in East Asia: Form State Building to PostDemocratisation (London: Continuum International, 2011), 48.

${ }^{72}$ Gerald Seymour Maryanov, Decentralization in Indonesia as a Political Problem (Singapore: Equinox, 2009), 26.

${ }^{73}$ Damien Kingsbury, Southeast Asia: A Political Profile, $2^{\text {nd }}$ ed. (Oxford: Oxford University Press, 2005), 356.

${ }^{74}$ Woo, Security Challenges and Military Politics in East Asia: Form State Building to Post-Democratisation, 51; Kingsbury, Southeast Asia: A Political Profile, 356.

${ }^{75}$ Woo, Security Challenges and Military Politics in East Asia: Form State Building to Post-Democratisation, 51.

${ }^{76}$ Ibid; Mietzner, Military Politics, Islam, and the State in Indonesia, 46-47.

77 David Jenkins, Suharto and His Generals: Indonesian Military Politics 1975-1983, Monograph Series Publication No. 64, $2^{\text {nd }}$ ed. (New York: Cornell Modern Indonesia Project, 1987), 3.

${ }^{78}$ Crouch, The Army and Politics in Indonesia, 346.

${ }^{79}$ Helen-Louise Hunter, Sukarno and the Indonesian Coup: The Untold Story (Westport: Prager Security International, 2007), 102.

${ }^{80}$ Jun Honna, Military Politics and Democracy in Indonesia (New York: Routledge, 2003), 216.
} 
associates, which is among one of the bloodiest episodes of modern history. ${ }^{81}$ With the PKI destroyed, Sukarno lost his grip on power and Suharto's TNI became the most dominant actor in Indonesia. ${ }^{82}$

Suharto became Indonesia's strongman, leading the country from 1966 until 1998, a period referred to as the 'New Order'. ${ }^{83}$ During the New Order, the TNI cemented its place in Indonesian society with the formalisation of $d$ wi fungsi (dual function) doctrine while civilian institutions remained even weaker than during Sukarno's Guided Democracy. Dwi fungsi went a step further than the Middle Way and explicitly noted that the TNI would be involved in "ideological, political, social, economic, cultural and religious fields." ${ }^{84}$ This allowed military officers to be involved in various government organisations that would otherwise be dominated by civilian leaders. This included senior civil service posts, governorships and ambassadorial posts. ${ }^{85}$ During the New Order, the TNI was granted approximately 75 of 414 seats in the Indonesian parliament, known as the People's Consultative Assembly (Majelis Permusyawaratan Rakyat Republik Indonesia: MPR). ${ }^{86}$ As well as the formal seats, it dominated the GOLKAR party which was essentially the government party for the entirety of the New Order; in effect, the TNI dominated the MPR outright.

As well as parliament, the $\mathrm{TNI}$ dominated politics at the regional level through the Territorial Command Structure (TCS) which operates in parallel with the weak civilian bureaucracy from Jakarta to the village-level (See Table 1 on the following page) ${ }^{87}$ The territorial structure was implemented as a result of General Abdul Haris Nasution's Territorial Warfare doctrine of 1962, which sought to limit the ability of the PKI and other internal groups from operating in the provinces. ${ }^{88}$ As well as the TCS, military officers were appointed as governors on the supposedly civilian side of regional politics. In 1965, 12 out of 24 governorships were headed by TNI officers. ${ }^{89}$ This had the effect of placing TNI

\footnotetext{
${ }^{81}$ Some estimates of the PKI purge are as high as 1.5 million; Kingsbury, Southeast Asia: A Political Profile, 357; Jenkins, Suharto and His Generals: Indonesian Military Politics 1975-1983, 4.

82 Jenkins, Suharto and His Generals: Indonesian Military Politics 1975-1983, 4.

${ }^{83}$ Marcus Mietzner and Lisa Misol, "Military Businesses in post-Suharto Indonesia: Decline, Reform and Persistence." in The Politics of Military Reform: Experiences from Indonesia and Nigeria, eds. Jürgen Rüland, Maria-Gabriela Manea and Hans Born (Heidelberg: Springer, 2013), 105.

${ }^{84}$ Crouch, The Army and Politics in Indonesia, 25 and 345.

${ }^{85}$ Michael Green "Indonesia's Armed Force in the Democratic Era” Centre for Strategic Studies New Zealand, CSS Strategic Briefing Papers, Vol. 6, Part 1. November, 2011, 1.

${ }^{86} 75$ is approximate because it changed slightly throughout. For an in-depth look at the TNI's seating arrangements in parliament throughout the New Order see Sukardi Rinakit, The Indonesian Military After the New Order (Copenhagen: Nordic Institute of Asian Studies, 2005), 159.

${ }^{87}$ Crouch, The Army and Politics in Indonesia, 222.

${ }^{88}$ Rinakit, The Indonesian Military After the New Order, 22-23.

${ }^{89}$ Crouch, The Army and Politics in Indonesia, 77.
} 
personnel at all levels of central and regional government. No other institution had this level of political clout.

TABLE 1: The TNI's Territorial Command Structure (TCS)

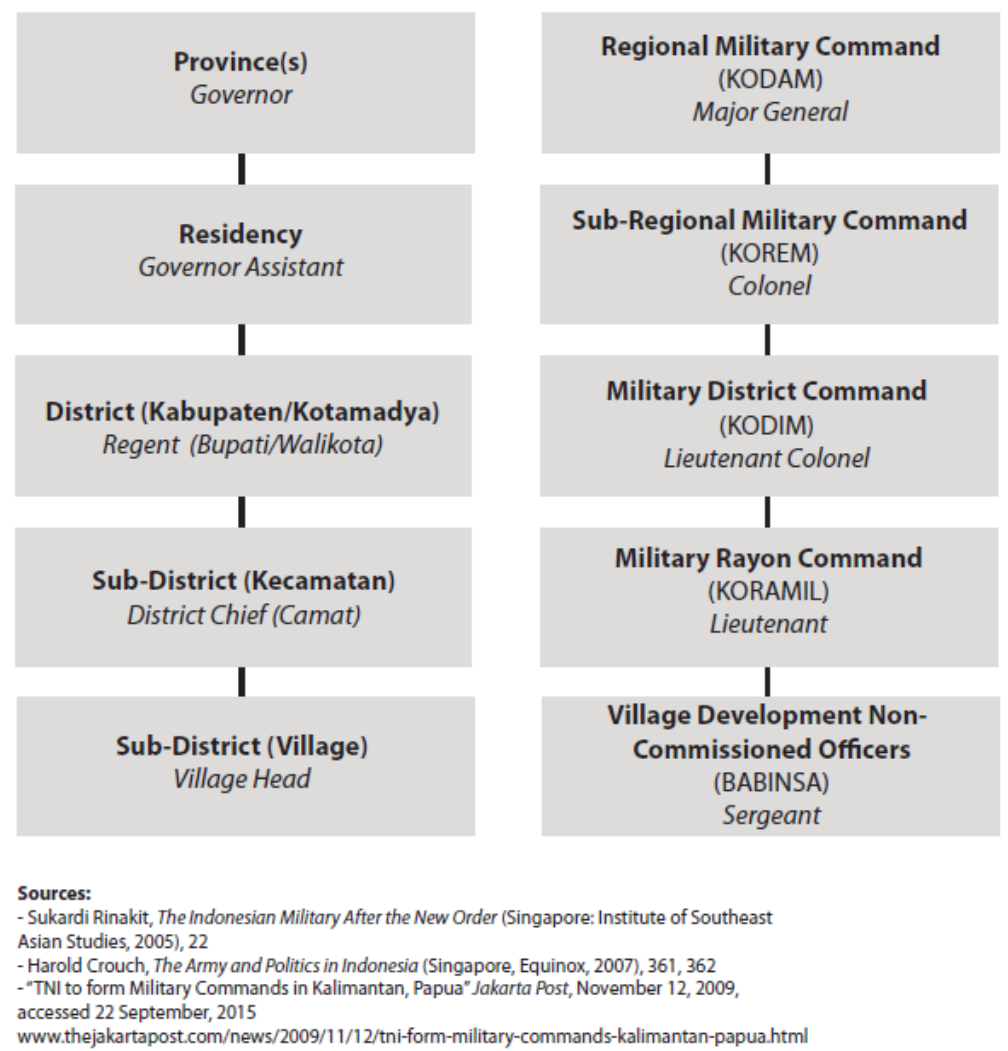

Indonesia's economy had grown steadily toward a newly industrialised status by the time the Asian Financial Crisis (AFC) hit in 1997. Suharto's New Order Government, formed under the conditions of the late 1960s and early 1970s, had not kept pace with the rapid economic and social change of the early 1990 s. $^{90}$ Societal factors, coupled with the sudden onset of AFC in 1997 saw Suharto's power slip. The rate of economic growth in Indonesia went from a positive eight percent in 1996, to a negative 14 percent in 1998 and the unemployment rate went from around 20 percent to 50 percent. ${ }^{91}$ This saw demonstrations throughout Indonesia demanding the resignation of Suharto. ${ }^{92}$ Suharto reluctantly agreed to

\footnotetext{
${ }^{90}$ Harold Crouch, Political Reform in Indonesia After Soeharto (Singapore: Institute of Southeast Asian Studies, 2010), 16

91 Ibid., 19; Kingsbury, Southeast Asia: A Political Profile, 363.

92 Kingsbury, Southeast Asia: A Political Profile, 365-366.
} 
cede power to his deputy Habibie, and announced that there would be presidential elections and that he would not stand. ${ }^{93}$ After three decades of authoritarian rule, Suharto's New Order government had come to an end.

The TNl's role in politics during the Guided Democracy and the New Order was often justified in terms of making up for the "weakness of civilian institutions." ${ }^{44}$ With the civilian population exhibiting strength and rising up against Suharto the support provided by the TNI to Suharto began to dwindle. "With the downfall of President Suharto, the military soon found itself under heavy public criticism and pressure that it should withdraw from politics sooner rather than later." 95

\section{THE INTERNAL SECURITY FOCUS OF THE TNI PRIOR TO DEMOCRACY}

"My politics are at the end of the bayonet."

Suharto, 1948

For much of its history, the TNI has been a force focused on internal security. Alagappa's argument that there is a direct correlation between a military's internal security role and that military's overall political influence is thus a solid theme for further analysis of the TNI. ${ }^{97}$ This section will explore the TNI's internal security role from independence until 1998 when the New Order administration came to an end. During the New Order, the TNI was the most dominant internal security actor in Indonesia. This section will argue that the core role of the TNI for much of its existence was internal security; it was an inward looking military. This was a contributing factor to the TNI becoming the most politically influential force in Indonesia.

The Revolution is often understood as a conflict between the Dutch and Indonesian Nationalists; however Dar al-Islam, a militant Islamist group, also took part in the conflict both against the Dutch and the Nationalists. ${ }^{98}$ As the Dutch ceded their claim to Indonesia, the Nationalists consolidated their power in the urban areas, while Dar al-Islam dominated

\footnotetext{
${ }^{93}$ Kingsbury, Southeast Asia: A Political Profile, 365-366.

${ }^{94}$ Michael R. J. Vatikotis, Indonesia Politics under Suharto: The Rise and Fall of the New Order (London: Routledge, 1993), 187.

${ }^{95}$ Rizal Sukma, "The Role of Civil Society in Indonesia's Military Reform." in The Politics of Military Reform: Experiences from Indonesia and Nigeria, eds. Jürgen Rüland, Maria-Gabriela Manea and Hans Born (Heidelberg: Springer, 2013), 148.

${ }^{96}$ Confidential communication between a retired TNI General and David Jenkins, November 10, 1981 cited in Jenkins, Suharto and His Generals: Indonesian Military Politics 1975-1983, 33.

${ }^{97}$ Alagappa, Coercion and Governance: The Declining Role of the Military in Asia, 498.

98 David Kilcullen, Counterinsurgency (London: Oxford, 2010), 88.
} 
the rural and mountainous interior. ${ }^{99}$ In the early 1960s, the TNI formulated a strategy to combat the Islamists. ${ }^{100}$ The TNI's pagar betis strategy ('fence of calves' or 'human fence') focused on defeating Dar al-Islam's ability to move and hide in the mountainous interior. ${ }^{101}$ The TNI focused on living with the population in order to deny Dar al-Islam access to rice paddies and other food sources. ${ }^{102}$ The Islamists were defeated by the TNI campaign in 1962. ${ }^{103}$ The TNI's Dar al-Islam saga further embedded the military with much of the population, which reinforced the territorial warfare strategy, the TCS and the TNI's self perception as the guardian of the Unitary State of Indonesia, codified in the Sapta Marga (the soldier's oath). ${ }^{104}$

With the defeat of Dar al-Islam, elimination of warlords throughout the island group and the successful invasion of Irian Java, the TNI became the most dominant force in Indonesia. ${ }^{105}$ As noted earlier, the TNI destroyed the PKI following the deaths of six TNI generals. During this time the military was again called into govern through martial law. ${ }^{106}$ With the PKI destroyed, Sukarno lost his grip on power and Suharto's TNI became the most dominant actor in Indonesia. ${ }^{107}$

The Police was militarised during the New Order. BRIMOB, the paramilitary force of the police, was responsible for counterterrorism until the TNI-AD's (Army) Detachment 81 was formed in 1982. ${ }^{108}$ A BRIMOB battalion was used in the initial invasion of East Timor in 1975, which resulted in the former Portuguese colony officially becoming a territory of Indonesia the following year. ${ }^{109}$ The TNI governed East Timor through the deployment of approximately 20,000 troops. $^{110}$ The TNI's conduct in the occupation of East Timor is

\footnotetext{
${ }^{99}$ Kilcullen, Counterinsurgency, 89.

100 Ibid.

101 Leonard Sebastian, Realpolitik Ideology: Indonesia's Use of Military Force (Singapore, Institute of Southeast Asian Studies, 2006), 126-127.

102 Ibid., 127.

${ }^{103}$ Paul J. Carnegie "Latent Insurgency: Is the Threat of Militant Islamist Groups in Indonesia Diminishing?" in, Insurgency and Counterinsurgency in Modern War, eds. Scott Nicholas Romaniuk and Stewart Tristan Webb (Boca Raton: CRC Press, 2015), 128.

${ }^{104}$ Leonard Sebastian and lisgindarsah, "Taking Stock of Military Reform in Indonesia." in The Politics of Military Reform: Experiences from Indonesia and Nigeria, eds. Jürgen Rüland, Maria-Gabriela Manea and Hans Born (Heidelberg: Springer, 2013), 30.

${ }^{105}$ Harold W. Maynard, "The Role of the Indonesian Armed Forces." in The Political Influence of the Military: A Comparative Reader, eds. Amos Perlmutter and Valerie Plave Bennett (New Haven: Yale University Press, 1980), 190.

${ }^{106}$ Honna, Military Politics and Democracy in Indonesia, 216.

107 Jenkins, Suharto and His Generals: Indonesian Military Politics 1975-1983, 4.

${ }^{108}$ Kenneth Conboy, South-East Asian Special Forces (Oxford: Osprey Publishing, 1991), 24; Leonard Sebastian, Realpolitik Ideology: Indonesia's Use of Military Force, 269.

${ }^{109}$ Conboy, South-East Asian Special Forces, 24; Crouch, The Army and Politics in Indonesia, 341.

${ }^{110}$ Constancio Pinto and Matthew Jardine, Inside the East Timor Resistance (Toronto: James Lorimer and Company, 1997), 246.
} 
remembered for its level of brutality and various human rights concerns, including the infamous Dili Massacre of 1991. ${ }^{111}$

\section{THE TNI'S CORPORATE INTERESTS PRIOR TO DEMOCRACY}

This sub-section will explore the TNl's involvement in economic activities in predemocratic Indonesia. Alagappa and Mietzner agree that the military will likely assume a greater role in the corporate world if its governance role is expanded, which perpetuates the increasing political influence of the military; analysis of the TNI's economic role in the predemocratic era supports this claim. This section will illustrate how the TNI became involved in the economy and how it increased its corporate interests especially during the New Order, consolidating its political influence further, largely as a result of the TCS.

As a guerrilla force during the Revolution, individual units that made up the TNI were self-sufficient, raising their operational budget from the population. ${ }^{112}$ Dutch intelligence reporting during the Revolution indicated that as well as legitimate businesses, TNI personnel were involved in opium smuggling, and other illicit activity. ${ }^{113}$ In 1957, Dutch owned businesses were nationalised, with many coming under the control of the TNI. ${ }^{114}$ With the declaration of martial law, TNI commanders at the regional level found themselves with preferential business conditions due to the central role of the military. ${ }^{115}$ Konfrontasi (Confrontation) over the formation of Malaysia saw the TNI take over British companies throughout the archipelago. ${ }^{116}$ In 1968, the TNI consolidated Indonesian oil and gas enterprises into a single company; for many years PT. Pertamina was the TNI's "major cash cow."117

The TCS provided, and still provides, the most significant opportunity for military commanders to profit from off-budget income. The TCS allows the TNI to conduct off-budget economic activities on a large scale because of its significant influencing role throughout the

\footnotetext{
${ }^{111}$ Pinto and Jardine, Inside the East Timor Resistance, 246; Lia Kent, The Dynamics of Transitional Justice: International Models and Local Realities in East Timor (Abingdon: Routledge, 2012), 181.

${ }^{112}$ Damien Kingsbury, Power Politics and the Indonesian Military (New York: Routledge, 2003), 198; Mietzner and Misol, "Military Businesses in post-Suharto Indonesia: Decline, Reform and Persistence." 104; Lex Rieffel and Jaleswari Pramodhawardani, Out of Business and on Budget: The Challenge of Military Financing in Indonesia (Washington DC: Brookings, 2007), 29.

${ }^{113}$ Kingsbury, Power Politics and the Indonesian Military, 198; Rieffel and Pramodhawardani, Out of Business and on Budget: The Challenge of Military Financing in Indonesia, 29.

${ }^{114}$ Richard Robinson, Indonesia: The Rise of Capital (Singapore: Equinox, 2009), 251; Kingsbury, Power Politics and the Indonesian Military, 199.

${ }^{115}$ Kingsbury, Power Politics and the Indonesian Military, 199.

116 Ibid.

${ }^{117}$ Rieffel and Pramodhawardani, Out of Business and on Budget: The Challenge of Military Financing in Indonesia, 32.
} 
entire bureaucracy. ${ }^{118}$ The structure gave rise to a patronage network throughout Indonesia. Commanders fostered partnerships with businessmen, creating off-budget funding for the TNI through informal, sometimes illegal activities. ${ }^{119}$ This gave commanders increased political influence in the regions and also provided them with the ability to accumulate personal wealth.

The foundations of the TNl's business activities were already well laid by the time Suharto took power in October 1965. During the New Order period, the TNI significantly expanded its reach into the Indonesian economy, by intensifying its operations; both the legal businesses and the other less formal activities. ${ }^{120}$ Suharto restricted the defence budget, which made TNI commanders more self-reliant on off-budget funding. ${ }^{121}$ At the same time Suharto controlled the access to many of the legal activities which "fostered a high degree of loyalty." ${ }^{122}$ By keeping commanders enmeshed in the patronage network, Suharto simply purchased loyalty through korupsi, kolusi dan nepotisme (corruption, collusion and nepotism - a popular slogan at the time describing Suharto's patronage network). ${ }^{123}$ Military commanders were receptive to Suharto's offer of "almost unlimited access to the resources and facilities of the state and power to influence allocation of import/export licences, forestry concessions and state contracts." 124 This provided Suharto with a loyal military and gave the TNI political influence through increased economic autonomy. ${ }^{125}$ In 1997, the AFC began to seriously affect the longevity of many TNI businesses, as well as other aspects of the Indonesian economy. ${ }^{126}$ This added to the growing pressure on Suharto to step down. Interestingly, as Suharto's patronage network felt the brunt of the AFC, the TNl's support of Suharto began to wane.

\footnotetext{
${ }^{118}$ Rieffel and Pramodhawardani, Out of Business and on Budget: The Challenge of Military Financing in Indonesia, 31.

119 Ibid., 25-31.

${ }^{120}$ Mietzner and Misol, "Military Businesses in post-Suharto Indonesia: Decline, Reform and Persistence." 105; Kingsbury, Power Politics and the Indonesian Military, 200.

${ }^{121}$ Rieffel and Pramodhawardani, Out of Business and on Budget: The Challenge of Military Financing in Indonesia, 32.

122 Ibid.

${ }^{123}$ Fiona Robertson-Snape, "Corruption, Collusion and Nepotism in Indonesia," Third World Quarterly 20, no.3, (1999): 589-602; Lex Rieffel and Jaleswari Pramodhawardani, Out of Business and on Budget: The Challenge of Military Financing in Indonesia (Washington D.C.: Brookings, 2007), 33.

${ }^{124}$ Mietzner and Misol, "Military Businesses in post-Suharto Indonesia: Decline, Reform and Persistence." 105.

${ }^{125}$ Rieffel and Pramodhawardani, Out of Business and on Budget: The Challenge of Military Financing in Indonesia, 32.

${ }^{126}$ Mietzner and Misol, “Military Businesses in post-Suharto Indonesia: Decline, Reform and Persistence.” 105.
} 


\section{PART TWO: THE POLITICAL INFLUENCE OF THE TNI \\ IN THE DEMOCRATIC ERA}

This part seeks to understand the TNI's political influence in the democratic era of Indonesian politics and will form an argument based on the framework presented in the theory chapter of this paper. The first section will discuss the weakness and strength of civilian institutions and leaders in the democratic era and how the TNI's political influence has largely receded in the democratic era, especially in the early years of reform (reformasi). The first section will also note that in recent years the TNI seems to be becoming more political than in the earlier years of reformasi. The second section will show that the TNI has largely remained focused on internal security, not external defence. The separation of the police from the TNI has been the most significant reform initiative with regards to internal security. The third section will argue that although the TNI was unable to avoid the economic consequences of very different political conditions in the democratic era, it still retains some influence as a result of its ability to make off-budget funds. This section will argue that overall the TNI has lost political influence in the democratic era. However, it remains politically orientated and retains a degraded level of influence. In recent years, the TNI has increasingly sought to re-enter the political realm.

\section{THE WEAKNESS OF CIVILIAN INSTITUTIONS AND THE SUBSEQUENT INVOLVEMENT OF THE TNI IN POLITICAL INSTITUTIONS IN THE DEMOCRATIC ERA}

The democratic era has seen the TNI recede politically, however it has not fully lost its political orientation. The TNI has lost its seats in the MPR but maintains its TCS. It has scrapped its infamous dwi fungsi doctrine but has reserved a trusted place in Indonesian society with strong links to the population. It has cut ties with the GOLKAR party and at the same time, retired officers are increasingly involved in political parties. This section seeks to understand the weakness of civilian institutions and the TNI's involvement in the political realm in Indonesia's democratic era. In recent years the TNI seems to be becoming increasingly more political than in the earlier years of reformasi. During the Jokowi era, the TNI's modus operandi seems to be more akin to dwi fungsi than to reformasi.

President Habibie's government lasted from May 1998 until October 1999. This period was the start of reformasi (Indonesia Reform Period from 1998) which saw significant reform of CMR in Indonesia, including the separation of the police from the TNI, the military reduce 
its share of seats in parliament and the military ceasing ties with the New Order's dominating GOLKAR Party. ${ }^{127}$ These reforms were defined and implemented by the TNI with no civilian oversight. This led to the omission of important reform items such as the TCS, which remains intact. ${ }^{128}$ The TNI kept a significant level of influence over Habibie because of his dependence on the support provided by the military. ${ }^{129}$

Writing at the time of Habibie's tenure, Andrew Renton-Green argued that most Indonesians, including the military, believed that Habibie did not have the ability to divorce himself from the influence of Suharto. In the view of many, Suharto remained the "dalang" (puppet-master). ${ }^{130}$ However, within a short period of replacing Suharto, Habibie announced that East Timor would be granted the right to independence. ${ }^{131}$ This outraged the TNI who had fought a counterinsurgency campaign in the province ever since it invaded the former Portuguese colony in 1975. The TNI supported various pro-integration militia groups with weapons and funding. ${ }^{132}$ It is hard to imagine East Timor being granted the right to independence under Suharto, or any other government strongly linked to the TNI. Therefore, this episode does in fact illustrate that Habibie felt he had enough political support and strength to not worry about the TNl's reaction. However the same episode shows how the TNI acted autonomously of the central government at that time, by supporting the various militia groups without the approval of central government. Habibie was replaced by President Abdurrahman Wahid on 20 October 1999, only seventeen months after Habibie was appointed.

Megawati Sukarnoputri, the daughter of Sukarno, was Wahid's main opponent in the 1999 election. ${ }^{133}$ Wahid was an unlikely president as he only received ten percent of the vote. ${ }^{134}$ However, Wahid was able to secure the support of a wide spread alliance of political parties, including the popular GOLKAR Party and smaller Islamic parties as well as all remaining representatives from the TNI. ${ }^{135}$ Such complex coalitions have become common

\footnotetext{
${ }^{127}$ Marcus Mietzner, The Politics of Military Reform in Post-Suharto Indonesia: Elite Conflict, Nationalism, and Institutional Resistance (Washington D.C: East-West Centre, 2006), 12.

128 Ibid., 6.

129 Ibid., 10.

${ }^{130}$ Andrew Renton-Green, “Indonesia after Soeharto: Civil or Military Rule," Centre for Strategic Studies: New Zealand, Working Paper No. 12 (1998), accessed March 10, 2015, http://www.victoria.ac.nz/hppi/centres/strategic-studies/publications/working-papers/WP12.pdf.

${ }^{131}$ Maiko Ichihara, "East Asia's Challenges to and Changes in the Peace Operations in East Timor," in Human Security in East Asia: Challenges for Collaborative Action, ed. Sorpong Peou (Abingdon: Routledge, 2009 ), 96. 132 Ibid.

${ }^{133}$ Kingsbury, South-East Asia: A Political Profile, 370.

134 Ibid.

${ }^{135}$ Marcus Mietzner, The Politics of Military Reform in Post-Suharto Indonesia: Elite Conflict, Nationalism, and Institutional Resistance, 16.
} 
in Indonesia's democratic politics and are referred to as 'grand coalitions' which are inherently weak and unstable. ${ }^{136}$

The TNI commander, Wiranto had supported Wahid instead of the incumbent Habibie. ${ }^{137}$ Wahid had noted that without the political support of the TNI, he would not have been able to become president; “You still can't become President of Indonesia without the military. They're out of the bureaucracy, and all of that, but that's nonsense. Nonsense! They're still strong, and Wiranto will support me to become President." ${ }^{138}$ Wanting to maintain political stability, Wahid supported Megawati to become the vice-president, which she did. ${ }^{139}$ There was a level of distrust between Wahid and TNI commanders, which was exacerbated when the President proposed Aceh be given a similar independence opportunity to East Timor, through a referendum. ${ }^{140}$ TNI commanders viewed civilian politicians, including Wahid, as amateurs, especially in regards to internal security concerns, like Aceh. ${ }^{141}$ The rise of political violence especially in Kalimantan and Aceh further exacerbated the fragmentary nature of Wahid's coalition to the point of unsustainability. This led to Wahid's impeachment in parliament in favour of Megawati. Wahid had simply alienated too many people within the military and political elite. ${ }^{142}$ The short tenure of the first democratically elected President of the post-Suharto era illustrates a weakness of the early democratic system; later presidents would last longer.

Megawati became Indonesia's fifth president in July 2001. Megawati did not push for reform within the $\mathrm{TNI}$ and is remembered as a "did nothing" president. ${ }^{143}$ As such, she maintained the support of the TNI for much of her presidency. ${ }^{144}$ Running up to the 2004 election, Megawati did little to change the widespread deteriorating public opinion of her government's effectiveness, something the TNI were keen to distance themselves from. ${ }^{145}$ Prior to the 2004 elections, the TNI relinquished all of its seats in the MPR. ${ }^{146}$ GOLKAR's nominee for the 2004 election, retired General Wiranto, was a strong contender for the 2004

\footnotetext{
${ }^{136}$ Sandra Hamid, "Indonesian Politics in 2012: Coalitions, Accountability and the Future of Democracy," Bulletin of Indonesian Economic Studies 48, no. 3, (2012): 326.

${ }^{137}$ Kingsbury, South-East Asia: A Political Profile, 371.

${ }^{138}$ Mietzner, The Politics of Military Reform in Post-Suharto Indonesia: Elite Conflict, Nationalism, and Institutional Resistance, 17.

${ }^{139}$ Kingsbury, South-East Asia: A Political Profile, 370-371

${ }^{140}$ Honna, "Security Challenges and Military Reform in Post-authoritarian Indonesia: The Impact of Separatism, Terrorism, and Communal Violence." 187.

141 Ibid.

142 Kingsbury, South-East Asia: A Political Profile, 378.

${ }^{143}$ Kingsbury, South-East Asia: A Political Profile, 378.

144 Ibid., 38-285.

145 Ibid., 378.

${ }^{146}$ Mietzner and Misol, "Military Businesses in post-Suharto Indonesia: Decline, Reform and Persistence." 106.
} 
elections, however it was another retired general who became the president in 2004, retired General Susilo Bambang Yudhoyono (SBY).

SBY of the Democratic Party was elected president with 60.8 percent of the vote in $2004 .^{147}$ Internal security remained a serious issue during the tenure of SBY. Sumatra, particularly Aceh, was the worst hit area following the Boxing Day Tsunami of 2004, with approximately 165,000 killed. ${ }^{148}$ This led the TNI and the Free Aceh Movement (GAM) to cease hostilities with a peace agreement. The compromise saw GAM renounce their claim to independence but establish a semi-autonomous region where sharia law was allowed to be implemented. $^{149}$ SBY remained president for a decade to the day (20 October $2004-20$ October 2014). SBY is remembered for conducting only modest reform, acting cautiously, however making some progress in the face of very difficult political and security circumstances. ${ }^{150}$

In the democratic era, POLRI reports directly to the president while the TNI report to the Minister of Defence; this is one positive democratic CMR development. ${ }^{151}$ However, the Ministry of Defence is still dominated by the TNI, with only limited civilian oversight and a retired general remaining the Defence Minister (General Ryamizard Ryacudu). The TNI also retains control of the Armed Forces Intelligence Agency (Badan Intelijen Strategis: BAIS). ${ }^{152}$ BAIS is one of two main intelligence agencies in Indonesia, the other being the State Intelligence Agency (Baden Intelijen Negara: BIN) which reports directly to the president and is directed by retired TNI General Sutiyoso. ${ }^{153}$

The 2014 election of Joko Widodo, commonly known as Jokowi, was viewed both domestically and internationally as a boost to democracy in Indonesia. ${ }^{154}$ Jokowi was seen as a president who "would break through the self-serving facades of vested interests hobbling the economy and the government, and deliver for the poor and deprived." ${ }^{155}$ The first year of Jokowi's presidency has seen him lose the support of parliament, and even his

\footnotetext{
147 The Report: Indonesia 2012 (London: Oxford Business Group, 2012 ), 17.

148 "Boxing Day Tsunami: How the Disaster Unfolded 10 Years Ago" ABC News, December 24, 2014, accessed October 7, 2015, www.abc.net.au/news/2014-12-24/boxing -day-tsunami-how-the-disater-unfolded/5977568.

${ }^{149}$ Niniek Karmini, "Victims of Aceh Conflict Await Justice in Indonesia” Irrawaddy, April 19, 2013, www.irrawaddy.org/asia/victims-of-aceh-conflict-await-justice-in-indonesia.html.

${ }^{150}$ Kingsbury, South-East Asia: A Political Profile, 391.

${ }^{151}$ Anthony L. Smith “Indonesia: Transforming the Leviathan" in Government and Politics in Southeast Asia, John Funston, ed. (Singapore: Institute of Southeast Asian Studies, 2001), 95.

152 Sebastian, Realpolitik Ideology: Indonesia's Use of Military Force, 79.

153 "Sutiyoso ready to lead BIN" Jakarta Post, June 10, 2015.

154 Hannah Beech, "A New Hope: Indonesian President Joko Widodo is a Force for Democracy," Time, October 27, 2014, 22-25; "Opening Indonesia: A Conversation with Joko Widodo," Foreign Affairs, November/December, 2014, 56-61.

155 Bob Lowry, "Jokowi-to be or not to be?," Australian Strategic Policy Institute, February 10, 2015, accessed September 27, 2015 www.aspistrategist.org.au/jokowi-to-be-or-not-to-be/.
} 
own party. ${ }^{156}$ The weakness of Jokowi's cabinet was on show during the 2015 Rohingya refugee issue. While Jokowi explained that Indonesia would assist resettling the refugees that landed on Sumatra, the TNI Commander General Moeldoko made comments that ran counter to Jokowi's, noting "we still have many problems in our country, and should not be burdened by this [Rohingya] problem." 157 This crisis shows that civilian oversight of the TNI, which is a prerequisite for democratic CMR, is still not fully implemented in Indonesia.

A significant political episode for Jokowi involved his initial police chief nominee Budi Gunawan, POLRI and the Corruption Eradication Commission (Komisi Pemberantasan Korupsi: KPK). KPK laid corruption charges against Gunawan the day before he was to be formally nominated in parliament. This led POLRI to lay criminal charges against the deputy chair of the KPK. ${ }^{158}$ This episode became extremely complex with the TNI effectively guarding the KPK buildings from POLRI retaliation and Megawati demanding Jokowi to do more to support Gunawan. ${ }^{159}$ This episode epitomises Jokowi's presidency thus far; it shows the strength of Megawati, the weakness of Jokowi, conflict between POLRI and the KPK, and manoeuvring by the TNI. Jakarta remains an extremely complex political environment.

\section{THE INTERNAL SECURITY ROLE OF THE TNI IN THE DEMOCRATIC ERA}

This section seeks to understand the TNI's role in internal security in the democratic era. It will argue that although significant shifts in Indonesia's internal security framework did occur in the first years of reformasi, notably the separation of the police from the TNI, the military has largely retained its focus on internal security, jostling with POLRI for leadership of the internal security domain. However, the TNI has lost political influence in the democratic era as it is no longer the sole arbiter of state violence in Indonesia.

From 1998 the goal of the New Paradigm, which was a term given to the military aspect of reformasi, was to "shift the TNI's traditional focus from internal security to external security." ${ }^{" 160}$ A practical aspect of the New Paradigm saw the police separate from the TNI in 1999, which implied that the newly established POLRI would be responsible for internal

\footnotetext{
${ }^{156}$ Bob Lowry, "Jokowi-to be or not to be?"

157 “Moeldoko Boasts of Feats During Tenure" Jakarta Post, July 8, 2015.

158 Lowry, "Jokowi-to be or not to be?."

${ }^{159}$ Zubaidah Nazeer, “Indonesia's President Jokowi drops Budi Gunawan as Police Chief Nominee" Straits Times, February 18, 2015, accessed October 3, 2015, www.staritstimes.com/asia/se-asia/indonesias-presidentjokowi-drops-budi-gunawan-as-police-chief-nominee; Jacqui Baker, "Jokowi's Police go Unpoliced," East-West Forum, May 4, 2015, accessed October 3, 2015, www.eastwestforum.org/2015/05/04/jokowis-police-gounpoliced/.

${ }^{160}$ Angel Rabasa and John Haseman, The Military and Democracy in Indonesia: Challenges, Politics and Power (Santa Monica: RAND, 2002), 26.
} 
security, while the TNI would be responsible for national defence. ${ }^{161}$ There was nothing novel about the New Paradigm; it had been drafted by reform minded officers in 1996 and 1997. ${ }^{162}$ From a political influence point of view, there were two points that the New Paradigm noted; the military was content not to be at the forefront of all national affairs and they acknowledged the necessity of role-sharing with other national forces. ${ }^{163}$ Statements made by the TNI and the closely aligned Ministry of Defence since, contradict the New Paradigm by noting that there remains a requirement for the TNI to be heavily involved in internal security operations. ${ }^{164}$ Thus, the TNI appears to be interested in retaining much of its historical internal security role.

The Ministry of Defence's White Paper of 2003 provides the justification for the TNl's internal security role in the democratic era, and thus illustrated a trend away from the New Paradigm. ${ }^{165}$ The White Paper argues that internal factors have the potential to disrupt and threaten Indonesia. ${ }^{166}$ The White Paper notes that it is the duty of the TNI to conduct so called Military Operations Other Than War (MOOTW), such as countering insurgency, combating international crime, aid to the civil community, humanitarian and peace tasks. ${ }^{167}$ The White Paper rightfully adds "MOOTW may create an impression on the confusion or an overlap between the role of the TNI with other institutions, especially on the authority of the POLRI in the case of general security and public order." ${ }^{168}$ The paper states that the TNI's role is "the use of armed force to overcome a threat." 169 Whereas POLRI's role is to "establish security and public order according to the rule of the law." ${ }^{170}$ The White Paper goes on to propose that the roles of the TNI and POLRI need to be stipulated based on the escalation level and threat spectrum. ${ }^{171}$ The White Paper is alluding to the TNI being responsible for threats from the medium to high end, including terrorism and insurgency whereas POLRI would be left with the lower end threats, including crime.

\footnotetext{
${ }^{161}$ Mikaela Nyman, Democratising Indonesia: The Challenges of Civil Society in the Era of Reformasi (Copenhagen: Nordic Institute of Asian Studies, 2006 ), 37.

162 Mietzner, The Politics of Military Reform in Post-Suharto Indonesia: Elite Conflict Nationalism, and Institutional Resistance, 11.

163 Ibid., 11-12.

1642003 Indonesian Defence White Paper: Defending the Country in the $21^{\text {st }}$ Century (Jakarta: Ministry of Defence, 2003, 9; Institute for Policy Analysis of Conflict interview with the Director General of Strategy, Ministry of Defence (Indonesia) April 14, 2015, in Institute for Policy Analysis of Conflict, "The Expanding Role of the Indonesian Military" IPAC Report No. 19, May 25, 2015, 8.

1652003 Indonesian Defence White Paper: Defending the Country in the $21^{\text {st }}$ Century (Jakarta: Ministry of Defence, 2003), 26.

166 Ibid.

167 Ibid., 45.

168 Ibid., 47.

169 Ibid.

170 Ibid.

171 Ibid.
} 
The separation of the police force from the TNI in 1999 caused competition between the two security agencies which was further exacerbated with the rise of terrorism. In 2002, Jemaah Islamiyah (JI) conducted an attack on a Bali nightclub which killed 202 people, including 88 Australians. ${ }^{172} \mathrm{Jl}$ conducted further large scale attacks on Western targets at the Marriott Hotel in Jakarta in 2002, the Australian Embassy in 2004 and another attack in Bali in $2005 .{ }^{173}$ The rise in terrorism, especially the Bali bombing of 2002, led the newly formed POLRI to establish a specialist counterterrorism squad, Detasemen Khusus 88 (Detachment 88). ${ }^{174}$ The development of Detachment 88 created a tense relationship between POLRI and the TNI who still saw themselves as the lead defence and security agency. ${ }^{175}$ The conflict between the TNI and POLRI is a point of contention that continues. ${ }^{176}$

The Institute for Policy Analysis of Conflict (IPAC) notes that even with POLRI's capabilities arguably sufficient to counter any terror threat to Indonesia, the TNI maintains specialist counterterrorism units within all three services (army, navy and air force). ${ }^{177}$ In early 2015, the TNI conducted so-called 'exercises' in the same area of Poso, Sulawesi where POLRI were conducting Operation Camar Maleo to capture Indonesia's most wanted terrorist, Santoso (also known as Abu Wardah). ${ }^{178}$ A TNI spokesperson said it was just a coincidence that the TNI were conducting exercises in the same remote region of Sulawesi where POLRI were conducting their operation. ${ }^{179}$ The competition over counterterrorism provides an insight into the current conflict between the TNI and POLRI and shows how the $\mathrm{TNI}$ is losing its historical influence derived from being the sole arbiter of state violence in Indonesia.

\section{THE TNI'S CORPORATE INTERESTS IN THE DEMOCRATIC ERA}

This section will explore the TNl's involvement in economic activities during the democratic era. Financial independence increases the political influence of the military and limits the ability of the central government to oversee the military's activities. Having the ability to fund initiatives that the civilian government has not budgeted for, allows the military

\footnotetext{
172 "The 12 October 2-2 Bali Bombing Plot" BBC, October 11, 2012, accessed October 15, 2015, www.bbc.com/news/world-asia-19881138.

${ }^{173}$ Timothy Mapes, Jeremy Wagstaff and Rin Hindrayati, “Bomb in Jakarta Kills Nine Outside Australian Embassy," Wall Street Journal, September 10, 2004, accessed October 5, 2015, www.wsj.com/articles/SB109470585484313350 accessed September 27 2015; Kingsbury, South-East Asia: A Political Profile, 388-389.

${ }^{174}$ Ed Davies and Olivia Rondonuwu, "U.S-Funded Detachment 88, Elite of Indonesia Security" Reuters, March 18, 2010, accessed September 27, 2015, www.reuters.com/article/2010/03/18/us-indonesia-usa-securityidUSTRE62H13F20100318.

1752003 Indonesian Defence White Paper: Defending the Country in the $21^{\text {st }}$ Century.

176 Institute for Policy Analysis of Conflict, "The Expanding Role of the Indonesian Military."

${ }^{177}$ Ibid.

${ }^{178}$ Ibid.

${ }^{179}$ Ibid.
} 
to bypass civilian policy processes and make decisions that may run counter to the interests of the government. ${ }^{180}$ This occurred in East Timor in 1999 where the TNI unofficially, and without the central government's mandate, backed pro-Indonesian militia groups. ${ }^{181}$ This is an example of the danger in allowing any democratic country's military to conduct off-budget economic activity.

The TNI headquarters and service branches own at least one foundation each, with the TNI-AD owning sixteen different foundations. ${ }^{182}$ These foundations, which were formed under Suharto's New Order, control holding companies that invest capital into individual businesses. ${ }^{183}$ Many of these TNI owned businesses operate in mining, construction, forestry, transportation, agribusiness, insurance, and airport management. ${ }^{184}$ At different levels of command, the TNI is involved in informal economic activities, some of which are illegal. The TNI collaborates with the private sector, including leasing publicly owned land and buildings for profit. $^{185} \quad$ A lucrative earner for the TNI is the security and protection services sector. In 2010 alone Freeport-McMoRan, a major Western mining multinational cooperation operating in Irian Jaya (West Papua), spent USD\$14 million on security measures provided by $3,000 \mathrm{TNI}$ and POLRI personnel. ${ }^{186}$ Illegal logging throughout Indonesia, but especially in Irian Jaya, is another key earner for the TNI. ${ }^{187}$

The TNI has lost economic clout as a result of the very different conditions of the post-Suharto era, and not because of the limited and contradictory reform measures instigated by the government. Under Suharto's New Order, TNI businesses had almost unlimited access to the resources of the state through the TCS. ${ }^{188}$ With the fall of Suharto, competition for enterprise ensued with the TNI, civilian politicians, emerging conglomerates, and the newly independent POLRI, all vying for resources. ${ }^{189}$ The territorial structure of the TNI has remained in the democratic era which means the economic opportunities presented via the system are still available today. Government led reforms have been contradictory and

\footnotetext{
${ }^{180}$ Mietzner and Misol, "Military Businesses in post-Suharto Indonesia: Decline, Reform and Persistence." 101. ${ }^{181}$ Ibid., 116.

${ }^{182}$ Human Rights Watch, Unkept Promise: Failure to End Military Business Activity in Indonesia (New York: HRW, 2010), 6.

${ }^{183}$ Sebastian, Realpolitik Ideology: Indonesia's Use of Military Force, 299-300; Human Rights Watch, Unkept Promise: Failure to End Military Business Activity in Indonesia Human Rights Watch, 6; Bagus BT Saragih, "TNI blasted for Not Handing over Businesses," Jakarta Post, March 12, 2011, accessed September 20, 2015, http://www.thejakartapost.com/news/2011/03/12/tni-blasted-not-handing-over-businesses.html.

${ }^{184}$ Sebastian, Realpolitik Ideology: Indonesia's Use of Military Force, 299-300.

${ }^{185}$ Human Rights Watch, Unkept Promise: Failure to End Military Business Activity in Indonesia, 2.

${ }^{186}$ This information is disclosed in their company's filling with the U.S. Securities and Exchange Commission; Mietzner and Misol, "Military Businesses in post-Suharto Indonesia: Decline, Reform and Persistence." 109; Harold Crouch uses a different source to verify the point that Freeport-McMoRan pays significant security service fees to the TNI; Crouch, The Political Reform in Indonesia after Soeharto, 166.

${ }^{187}$ Mietzner and Misol, "Military Businesses in post-Suharto Indonesia: Decline, Reform and Persistence." 109.

${ }^{188}$ Ibid., 105.

189 Ibid., 106.
} 
ambiguous enabling the TNI to retain many business interests. In 2004, President Megawati Sukarnoputri signed Law No. 34/2004 which banned all TNI personnel from involvement in business activities and required the TNI to relinquish ownership of all businesses to the central government within five years. ${ }^{190}$ However, with the October 2009 deadline approaching President Susilo Bambang Yudhoyono (SBY) issued Presidential Decree No.43/2009 which is viewed by the Human Rights Watch as a serious reversal of previous reform initiatives set out in Law No. 34/2004. ${ }^{191}$ As of 2008 the TNI continued to own between 1,335 (independent inventory) and 1,153 (government inventory) business entities, across most sectors. ${ }^{192}$

The TNI cite the inability of the central government to provide adequate funds for the defence budget as the core reason for the TNI bolstering its funding through profiteering. ${ }^{193}$ In 2000, the then Minister of Defence Juwono Sudarsono announced that the budget only covered 30 percent of the TNI's requirements. ${ }^{194}$ Therefore, the TNI required well over half of its funding to come from off-budget sources. In 2005, Juwono adjusted the figure to 50 percent, meaning that for the TNI to function, it still required significant funding from offbudget means. ${ }^{195}$ In 2010, Juwono noted to Lisa Misol that the government now provided 80 percent of the budget. ${ }^{196}$ Mietzner notes that it is impossible to establish what the real budget looks like but Juwono's vantage point, as the then Minister of Defence, is "the closest to a workable approximation." ${ }^{\prime 197}$ The TNI's increasing reliance on the central government will likely decrease the political influence of the TNI further.

\section{CONCLUSION OF CHAPTER TWO}

Part one of this chapter focused on understanding the extent of the TNl's political influence from the Revolution until Suharto stood down in 1998. The first section illustrated how the TNI became involved in politics in the first place, during the Revolution, and how it dominated politics until 1998. As noted by Habibie, the TNI was the most dominant political actor during the Revolution, while civilian leaders remained weak and divided. Civilian institutions remained weak throughout the early democratic period which followed the Revolution, largely as a result of the fragmentation of civilian political entities. During the

\footnotetext{
${ }^{190}$ Human Rights Watch, Unkept Promise: Failure to End Military Business Activity in Indonesia, 3.

${ }^{191}$ Mietzner and Misol, "Military Businesses in post-Suharto Indonesia: Decline, Reform and Persistence." 113; Human Rights Watch, Unkept Promise: Failure to End Military Business Activity in Indonesia, 1.

${ }^{192}$ Mietzner and Misol, "Military Businesses in post-Suharto Indonesia: Decline, Reform and Persistence." 107.

193 Richard Robison, Indonesia: The Rise of Capital, 255.

194 Mietzner and Misol, "Military Businesses in post-Suharto Indonesia: Decline, Reform and Persistence." 110111.

195 Ibid., 111.

196 Ibid., 110.

197 Ibid., 111.
} 
Guided Democracy, the TNI remained the dominant political institution, only being challenged briefly by the PKI which was destroyed shortly thereafter. During Suharto's New Order, the TNI replaced its Middle Way doctrine in favour of $d w i$ fungsi which cemented the TNI's domestic role. The second section showed how the TNI has its roots in internal security rather than external defence, which further expanded its political influence. The TNI has been involved in a number of counterinsurgency campaigns, the most notable of which include the conflict against Dar al-Islam and the occupation of East Timor. The strong internal security role of the TNI allowed it to become enmeshed in the nation's fabric through the TCS. The third section explored the political effect of the TNl's corporate interest prior to democracy. It was found that the TNl's ability to create off budget funding enabled a level of autonomy from central government, even during the New Order when the TNI and Suharto were in close association. The culminating argument of this section is that prior to democracy the TNI was the most politically influential institution in Indonesia, both at the central government level in Jakarta and at the village level through its TCS.

Part two of this chapter analysed the extent of the TNl's political influence in the democratic era. In conclusion, it should be noted that the TNI has lost political clout as a result of reform undertaken in the wake of the democratic era. Reformasi saw the TNI give up its seats in the MPR, cease ties with the GOLKAR party and shelve its $d w i$ fungsi doctrine. However, important reform items were omitted from reformasi, including the TCS which remains intact and allows the $\mathrm{TNI}$ to influence politics throughout the regions. Habibie's decision to allow East Timor the right to independence was an illustration of the changing times. However, the TNI showed their political desires by backing militia groups, something that was made possible through the TNI's corporate interests. Although the TNl's self induced New Paradigm took practical steps toward increasing democratic CMR, namely the separation of the police from the armed forces, the TNI has retained its focus on internal security, jostling with POLRI for leadership of the internal security domain. The competition between the TNI and POLRI was recently on show in Poso, Sulawesi where both POLRI operations and $\mathrm{TNI}$ exercises conflictingly sought to neutralise the same terrorist leader, Santoso (also known as Abu Wardah). The Poso incident of 2015 show that the TNI is not content in losing its internal security role. As the TNl's governance role declined, so too has its involvement in the corporate world. Whereas legal reforms were sidestepped, the TNI was unable to avoid the economic consequences of very different political conditions in the democratic era. However, it should be stressed that the TNI is still very much involved in making off-budget profits which enables a degree of independence and supports the TNl's ongoing, albeit reduced, political influence, as well as providing personal wealth to TNI elite. 
To conclude, and to answer the first aspect of the core question of this paper; the TNI has lost significant political influence in the democratic era but remains politically engaged. Signs that the TNI has lost influence include it loss of seats in parliament, its scrapping of ties with political parties and the separation of the police from the military. Signs that the TNI retains a political orientation include its retention of the TCS, competition with POLRI over internal security and its continuation of a number of corporate interests, which also hinders democratic CMR. 


\section{CHAPTER THREE:}

\section{THE POLITICAL INFLUENCE OF THE TATMADAW}

Located in the Bay of Bengal and the Andaman Sea, Myanmar is a country surrounded by approximately one third of the world's total population, sharing land borders with Bangladesh, India, China, Laos and Thailand (See Map 2 on the following page). ${ }^{198}$ Myanmar's population of 56 million inhabitants are predominantly Buddhist, with Christian and Muslim minorities. ${ }^{199}$ The population is officially derived from the following major ethnic groups; Kachin, Kayah, Kayin, Chin, Mon, Rakhine, Shan and the majority Bamar who make up 67.9 percent of the population. ${ }^{200}$ Officially the seven major ethnic groups are further divided into 135 so called sub-nationality groups. The government does not recognise certain ethnic groups as legitimate, including the Muslim minority referred to as the Rohingya who Naypyidaw argues are illegal immigrants from Bangladesh. ${ }^{201}$ Without getting into the detail, it is suffice to say that Myanmar is ethnographically complex, however dominated by the majority Bamar. ${ }^{202}$

Since independence from the British in 1948, Myanmar has been dominated by its Armed Forces, the Tatmadaw who have ruled over the country through junta-style governments. ${ }^{203}$ Armed conflict has remained commonplace in Myanmar where ethnic groups have sought independence from the Bamar dominated junta. ${ }^{204}$ The economy, formerly one of the most developed in Southeast Asia, has been devastated by years of mismanagement under the military government. ${ }^{205}$ For much of the past five decades, Myanmar was described as a closed economy. ${ }^{206}$ In the 1950 s, over 20 percent of

\footnotetext{
198 Prior to 1989, the Union of the Republic of Myanmar was referred to as the Union of Burma. For purposes of continuity 'Myanmar' is used throughout this paper to describe the country both before and after 1989, unless directly quoted as Burma.

199 “Burma," Central Intelligence Agency World Factbook, accessed October 19, 2015, www.cia.gov/library/publications/the-world-factbook/.../bm.html.

${ }^{200}$ Tin Maung Maung Than, "Ethnic Insurgencies and Peacemaking in Myanmar." in ISEAS Perspectives: Selections 2012-2013, ed. Ooi Kee Beng (Singapore: Institute of Southeast Asian Studies, 2014), 105.

${ }^{201}$ Alistair C. B. Cook, "Displacement along Myanmar's Borders." in Irregular Migration and Human Security in East Asia, ed. Jiyoung Song and Alistair C. B. Cook (Abingdon: Routledge, 2015), 71-74; Z B Bahruddin, "Plight of Rohingya People Goes International as Myanmar Reforms Stagnate," Asian Defence Journal, December, 2014, 4-5.

202 Than, "Ethnic Insurgencies and Peacemaking in Myanmar." 105.

${ }^{203}$ Susanne Prager Nyein, "The Armed Forces of Burma." in The Political Resurgence of the Military in Southeast Asia: Conflict and Leadership, ed. Marcus Mietzner (Abingdon: Routledge, 2011), 24.

${ }^{204}$ Maung Aung Myoe, "The Military and Political Liberalisation in Myanmar." in Myanmar in Transition: Polity, People and Processes, ed. Kerstin Duel I (Singapore: Konrad-Adenauer Stiftung, 2013), 62-63.

${ }^{205}$ Robert H. Taylor, General Ne Win: A Political Biography (Singapore: Institute for Southeast Asian Studies, 2015), 543-545.

${ }^{206}$ Chong-Yah Lim, Southeast Asia: The Long Road Ahead (Singapore: World Scientific Publishing, 2004), 55.
} 
Myanmar's GDP was derived from the export market; this was reduced to a mere one and a half percent by the 1990 s. $^{207}$

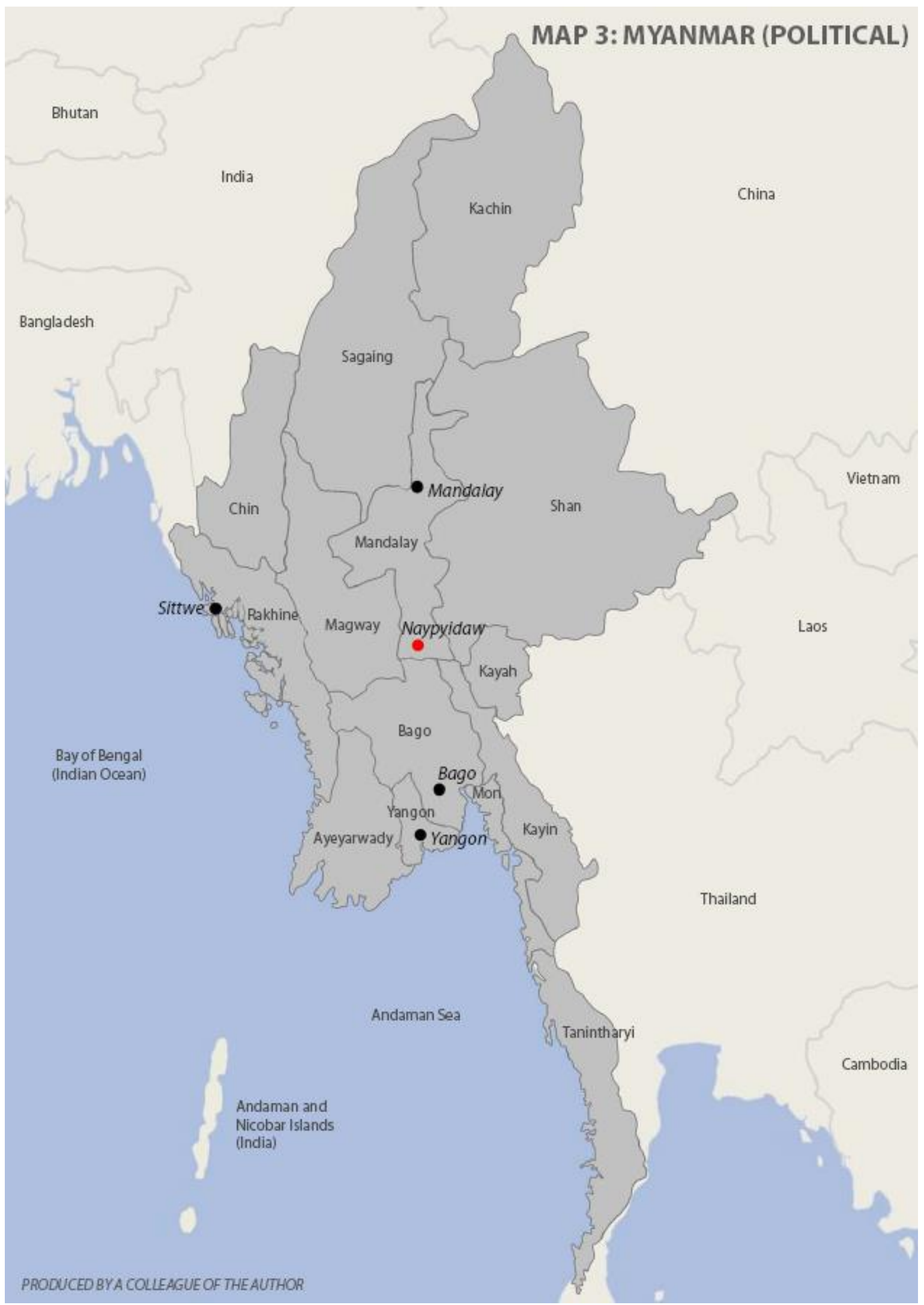

${ }^{207}$ Chong-Yah Lim, Southeast Asia: The Long Road Ahead, 55. 
The country's climate and rich agricultural land is underutilised as a result of economic mismanagement and the practical restrictions of manual labour; farming methods have remained largely constant for decades, employing simple ploughs, water buffalos and natural fertilizers. ${ }^{208}$ As such, the agricultural sector in Myanmar has considerable opportunities for expansion if its infrastructure is modernised and it's economy opened up to the world. ${ }^{209}$ This seems plausible given President Thein Sein's comments promoting the liberalisation of Myanmar's economy and the possible democratisation of the political structure. ${ }^{210}$ However, opposition leader and democratic icon Aung San Suu Kyi (ASSK) has warned of being overly optimistic. ${ }^{211}$ She has a point; Myanmar is home to the world's longest serving military dictatorship. ${ }^{212}$

This chapter will be made up of two sections. The first section characterises the historical developments that led to the growth of the Tatmadaw's political role and subsequent political influence. The second section will use an analytical methodology referred to as the cone of plausibility to assist in providing plausible scenarios on the likely political influence of the Tatmadaw in a future democratic Myanmar.

\footnotetext{
${ }^{208}$ William J. Topich and Keith A. Leitich, The History of Myanmar (Santa Barbara: Greenwood, 2013), 73.

${ }^{209}$ Organisation for Economic Co-operation and Development (OECD), OECD Development Pathways: Multidimensional Review of Myanmar - Volume 2: In-Depth Analysis and Recommendations (Paris: OECD Publishing, 2014), 49.

210 "Timeline: Reforms in Myanmar" BBC News, July 8, 2015, accessed October 12, 2015, www.bbc.com/news/world-asia-16546688.

${ }^{211}$ Kyaw Phyo Tha, "US Too Optimistic about Burma Reform : Suu Kyi” Irrawaddy, November 5, 2014, accessed October 12, 2015, www.irrawaddy.org/burma/us-optimistic-burma-reform-suu-kyi.html.

212 Than Than Nu "From Exile to Elections." in Debating Democratization in Myanmar, eds. Nick Cheesman, Nicholas Farrelly and Trevor Wilson (Singapore: Institute of Southeast Asian Studies, 2014), 95.
} 


\section{PART ONE:}

\section{THE POLITICAL INFLUENCE OF THE TATMADAW: 1948-2015}

This part is made up of three sections, each illustrating the political influence of the Tatmadaw alongside the framework produced from the theory chapter of this paper. Three parts will be organised chronologically from the early development of the Tatmadaw during the Second World War, though to immediately prior to the November 2015 elections. Section one will show that the Tatmadaw first became involved in politics during the struggle for independence. Since then, the Tatmadaw has remained the most politically influential actor in Myanmar, with a significant share of seats in parliament and a dominant role in various governments. The second section will illustrate that the Tatmadaw has been a force focused on internal security, as apposed to external defence. Over the past five decades the Tatmadaw has ruled over Myanmar and been the most politically influential force in the country largely as a result of its capability to conduct violence. As a result of its overreliance on coercion, the Tatmadaw has arguably lost much of its domestic legitimacy and credibility as a so-called patriotic institution, a concept it views as important. ${ }^{213}$ The third section will explore the Tatmadaw's corporate interests and its effect on influence. Section three will struggle to comprehend how the most politically influential institution in Myanmar could possible garnish more political clout through its corporate interests.

\section{THE WEAKNESS OF CIVILIAN INSTITUTIONS AND THE INVOLVEMENT OF THE} TATMADAW IN POLITICS: 1948-2015

For five decades the Tatmadaw has been the sole administrator and builder of Myanmar. ${ }^{214}$ This section will describe how this came about and why after so long, the military is still the most powerful political entity in Myanmar. This section will argue that the military has retained its dominance by taking advantage of weak civilian governance on a number of occasions, including the establishment of the 1958 military caretaker government, the 1962 coup and the military's political role in the 2008 constitution. Although modest reform toward democracy has taken place in recent years, the military is still firmly at the helm in Naypyidaw, directly with a significant share (25 percent) of parliamentary seats and indirectly through a very close association with the quasi-civilian ruling party, the Union Solidarity and Development Party (USDP).

\footnotetext{
${ }^{213}$ Than Than Nu "From Exile to Elections." 95.

${ }^{214}$ Nyein "The Armed Forces of Burma." 24.
} 
The military's central role in establishing an independent Myanmar provided the foundation for its later role as the country's dominating political entity. During the Second World War, a group of nationalists, led by Aung San, father of ASSK, began a rebellion against the British colonial administration, based in Yangon. ${ }^{215}$ Aung San formed the Burmese Independence Army (BIA) in 1941 with the support of the Japanese, who then invaded the British colony the following year. In 1945, the BIA turned on their supporters and engaged the Japanese in guerrilla-style warfare. ${ }^{216}$ The British returned to Yangon soon after Japanese capitulation, and established the Burma Army, disbanding the BIA. ${ }^{217}$ Aung San left the army and formed the Anti-Fascist People's Freedom League (AFPFL), maintaining pressure on the British until 1948, when London decided to grant Myanmar independence. ${ }^{218}$

The weakness of civilian institutions in the years immediately after independence directly resulted in the military gaining significant political clout. This allowed the military to effectively become the government; gaining the most political influence any institution can yield. Shortly after independence, civil war broke out across Myanmar which meant that the newly formed government struggled to settle into political normality, while the military's role expanded. This resulted in the Tatmadaw dominating the civil-military dynamic as it had such an important role to play in quelling violence throughout the country. ${ }^{219}$ The complex security situation was further exacerbated with the threat posed by Kuomintang troops intruding along the northern border from China. This had the effect of strengthening the operational capabilities of the Tatmadaw as the organisation was provided with extra resources. $^{220}$

In 1958, as the ruling civilian party (AFPFL) fragmented, General Ne Win displaced the civilian government and implanted a military caretaker Revolutionary Council. ${ }^{221}$ The Council "quashed the opposition, dismantled civil society with the exception of religious associations." 222 Ne Win returned Myanmar to civilian rule in 1960, only for the Tatmadaw to conduct a coup in 1962 and supplant the entire political and economic system. ${ }^{223} \mathrm{Ne}$ Win's

\footnotetext{
${ }^{215}$ Yangon was historically referred to as Rangoon until 1989 when Burma became Myanmar. This paper will refer to the city, the largest in Myanmar, as Yangon.

${ }^{216}$ Susanne Prager Nyein, "The Armed Forces of Burma.", 24.

217 Ibid.

218 Ibid.

219 Ibid., 25.

220 Ibid., 25.

${ }^{221}$ Anaud, "The Role of Myanmar's Military in Democratic Transition and Implications or India," Vivekananda International Foundation, Occasional Paper, December, 2013, 3.

222 Susanne Prager Nyein, "The Armed Forces of Burma.", 26.

${ }^{223}$ Myoe, "The Military and Political Liberalisation in Myanmar." 60; Anaud, "The Role of Myanmar's Military in Democratic Transition and Implications or India," 3-4.
} 
government remained in place until 1974 when it was replaced with a Tatmadaw civilian look alike, the Burma Socialist Program Party (BSPP). ${ }^{224}$ BSPP's one party government was made up of retired and serving Tatmadaw officers; the BSPP was in effect a "civilian veneer" of the Tatmadaw. ${ }^{225}$ As its name suggested, the BSPP was of a Marxist-Leninist persuasion and was inward looking, shutting much of the world out for decades.

An economic meltdown in 1988 led to widespread protests and a collapse of the BSPP government. ${ }^{226}$ For many Burmese, it seemed as if democratic reform was not just "possible but inevitable."227 However, the Tatmadaw crushed this idea shortly thereafter by deploying forces into urban areas to displace protestors, killing thousands of unarmed civilians. ${ }^{228}$ The Tatmadaw then established a junta government in the State Law and Order Restoration Council (SLORC). This was not a coup but merely a continuation of Ni Win's military government without its civilian veneer. ${ }^{229}$ In the 1990 general elections, ASSK's National League for Democracy (NLD) won over 80 percent of the parliamentary seats and 60 percent of the popular vote. ${ }^{230}$ The outcome of 1990 election was overturned by the junta in favour of the SLORC, while the military suppressed its main civilian opposition, the NLD. ${ }^{231}$ In 1997, the junta rebranded from SLORC to the State Peace and Development Council (SPDC). SPDC joined ASEAN in 1997, moved their administrative capital inland from Yangon to Naypyidaw in late 2005, drafted a new constitution in 2008, opened up aspects of the economy and announced elections for $2010 .^{232}$ This was the start of a new period of contradictory political and economic reform.

The constitution illustrates how the Tatmadaw seeks to hold onto aspects of political influence while ensuring civilian institutions remain weak. Clause 109 notes that the Tatmadaw will be automatically assigned 25 percent of the seats in both the upper house (Amyotha Hluttaw) and lower house (Pyithu Hluttaw) of the parliament (Pyidaungsu

\footnotetext{
${ }^{224}$ Myoe, "The Military and Political Liberalisation in Myanmar." 60.

${ }^{225}$ Nyein, "The Armed Forces of Burma." 26.

${ }^{226}$ Myoe, "The Military and Political Liberalisation in Myanmar." 60.

227 Mary P. Callahan, "Burma: Soldiers as State Builders." in Coercion and Governance: The Declining Political Role of the Military in Asia, ed. Muthiah Alagappa (Stanford: Stanford University Press, 2001) 423.

${ }^{228}$ Win Min, "Internal Dynamics of the Burmese Military: Before, during and after the 2007 Demonstrations," in Dictatorship, Disorder and Decline in Myanmar, eds. Monique Skidmore and Trevor Wilson (Canberra: Australian National University, 2008), 37.

${ }^{229}$ Nyein, "The Armed Forces of Burma." 26.

${ }^{230}$ Human Rights Watch, Vote to Nowhere: The May 2008 Constitutional Referendum in Burma (New York: HRW, 2008) 14.

${ }^{231}$ Hnin Yadana Zaw, “Myanmar Military Retains Veto after Opposition Change Vote Fails," Reuters, June 25, 2015, accessed October 19, 2015, www.yahoo.com/myanmar-parliment-voting-amending-key-parts-ofconsitiution-074822297.html.

${ }^{232}$ Shaun Narine, Explaining ASEAN: Regionalism in Southeast Asia (Boulder: Lynne Rienner, 2002), 116; Richard Cockett, Blood, Dreams and Gold: The Changing Face of Burma (Padstow: TJ International, 2015$), 68$.
} 
Hluttaw). ${ }^{233}$ To make amendments to the constitution, 75 percent of the Pyithu Hluttaw must agree, something very unlikely without the backing of the military. ${ }^{234}$ It would require the support of every non-Tatmadaw politician, including civilian politicians who support or have strong associations with the military, such as the USDP. As such, the military effectively wields a veto and has the ability to overpower elected political actors. As well as the Tatmadaw's assigned seating, the constitution has a built-in coup d'état clause whereby the military can be authorised by the President to conduct a coup to re-establish military control. ${ }^{235}$ The constitution bans people with children to a foreign citizen from becoming the president. This clause appears to be aimed at preventing ASSK from becoming president as she has two children to a Briton.

ASSK boycotted the referendum on the 2008 constitution and 2010 elections but did finally become a member of parliament in the 2012 by-election. ${ }^{236}$ ASSK, who now represents Kawhmu Township (Yangon Region) in the Pyithu Hluttaw, is arguably the most popular politician in Myanmar. ${ }^{237}$ The fact that she can not become president without changes to the constitution illustrates the weakness of civilians and the strength of the military in Myanmar's constitutional framework; the military's dominance of politics and the weakness of civilian institutions is thus concrete until the military is itself willing to cede control to civilians. Due to her inability to become president, there is an inherent requirement for ASSK to bolster the leadership ranks of the NLD, something she seems unwilling to do. ${ }^{238}$ Even though the party is popular, the fact that the NLD lacks alternative leadership options directly limits the capacity of the NLD to gain a dominant role in the Pyidaungsu Hluttaw.

The military backed USDP won 883 of 1154 seats in the 2010 election. ${ }^{239}$ The following year, Thein Sein was inaugurated as the first post-SPDC president. The fact that Thein Sein is a retired general and that the military-backed party won such a resounding victory (close to 60 percent) in the establishment of the quasi-civilian administration, led

\footnotetext{
${ }^{233}$ Constitution of the Republic of the Union of Myanmar (Naypyidaw, Printing and Publishing Enterprise Ministry of Information, 2008), 39.

${ }^{234}$ Renaud Egreteau, "Myanmar: Transition, Praetorian Politics, and the Prospects for Democratic Change" in Routledge Handbook of Southeast Asian Democratization, ed. William Case (Abingdon: Routledge, 2015), 419.

${ }^{235}$ Susanne Prager Nyein, "The Armed Forces of Burma." 28-29.

${ }^{236}$ Cockett, Blood, Dreams and Gold: The Changing Face of Burma, 197.

${ }^{237}$ Andrew McLeod, "Aung San Suu Kyi Still in Running or Myanmar Presidency," BBC World News, July 10, 2015, accessed October 18, 2015, www.bbc.com/news/world-asia-33476250; Colonel (rtd.) Hla Min, The Way I See It: Myanmar and its Evolving Global Role (Yangon: Zin Yadanar Saw Publishing House, 2013), III.

${ }^{238}$ Min Zin, “Is Burma's Opposition Ready for the Post-Aung San Suu Kyi Era?," Foreign Policy, August 18, 2015, accessed October 18, 2015, www.foreignpolicy.com/2015/08/18/is-burmas-opposition-ready-for-the-postaung-san-suu-kyi-election/.

${ }^{239}$ David Henry Poveter, "Myanmar's Roadmap Comes Full Circle," Asia Times, September 14, 2011, accessed October 18, 2015, www.atimes.com/atimes/Southeast Asia/MI14Ae01.html.
} 
opposition groups and other countries alleging that the general election, the first in 20 years, was nothing more than a "sham." ${ }^{240}$ The Tatmadaw on the other hand argue that the 2010 election marks the transition-point from military rule to a civilian democracy, even though the military still have a significant share of the seats in parliament and Tatmadaw officers dominate the ruling party. ${ }^{241}$ The USDP has essentially retained the status quo of a military backed government while instigating all but limited reform initiatives, namely the release of thousands of political prisoners, including ASSK, the relaxation of censorship laws and the abolishment of a 25 -year-old ban on public gatherings of more than five people. ${ }^{242}$ Modest reform has seen the easing of sanctions by several Western nations, a second order effect of which has seen foreign investment "flood" into Myanmar. ${ }^{243}$ Western interest in Myanmar has increased as a result. Western leaders have begun flocking to Naypyidaw. In 2014, this included U.S President Barack Obama, Australian Prime Minster Tony Abbott and New Zealand Prime Minister John Key. ${ }^{244}$

Retired Tatmadaw officers have played an important role in the quasi-civilian administration, namely as members of the USDP. As a result, their influence is likely tied to the overall posture of the Tatmadaw, the USDP's core supporter. Although in the quasicivilian era, retired Tatmadaw officers make up only a small minority of parliament (less than 12 percent), they are disproportionately represented in more powerful legislative positions in parliament, such as speakerships. ${ }^{245}$ In a 2015 report, Renaud Egreteau argues that this shows where the power lies in Myanmar; in the hands of serving and retired Tatmadaw officers. ${ }^{246}$ The top two generals of the SPDC era, Senior General Than Shwe (former chairman of SPDC) and Vice-Senior General Maung Aye (former vice chairman of the SPDC), retired when the USDP was founded. It is believed these two personalities still continue to exercise some power over the USDP government. ${ }^{247}$ Although there are certainly going to be cases on the contrary, due to their inherent institutionalisation, retired military officers are likely to represent the interests and values of their former service more so than

\footnotetext{
240 Trevor Wilson, "The Significance of Myanmar's 2010 Election," New Mandala, December 15, 2010, accessed October 18, 2015 www.asiapacific.anu.edu.au/newmandala/2010/12/15/the-significance-ofmyanmar\%E2\%80\%99s-2010-election/.; "Timeline: Reform in Myanmar" BBC World News.

${ }^{241}$ Myoe, "The Military and Political Liberalisation in Myanmar." 60.

242 "Timeline: Reform in Myanmar," BBC World News.

243 "The Square Mile: After Years of Stagnation, Myanmar's Biggest City is Developing at Last," Economist, January 31, 2015, accessed October 19, 2015, www.economist.com/news/asia/21641296-after-yearsstagnation-myanmar-biggest-city-developing-last-square-mile.

244 Sarah Robson, "Trade on John Key's Mind in Myanmar," 3 News, November 13, 2014, accessed October 18, 2015, www.3news.co.nz/nznews/trade-on-john-keys-mind-in-myanmar-2014111306\#axzz3pBH2Eiae.

${ }^{245}$ Renaud Egreteau, "Retired Military Officers in Myanmar's Parliament: An Emerging Legislative Force?," Trends in Southeast Asian Studies, (Singapore: Institute of Southeast Asian Studies, 2015), 28.

246 Ibid.

247 Anaud, “The Role of Myanmar's Military in Democratic Transition and Implications or India," 8.
} 
others without a military background. As noted by Aung Sun Suu Kyi, "just because you change out of military uniform to civilian clothes, it does not mean your mind-set changes automatically."248

Myanmar is overwhelmingly Buddhist. Myanmar's 400,000 Buddhist monks, spread across 45,000 monasteries, are interestingly "comparable in number to the Tatmadaw."249 Although not a "homogeneous mass," the Sangha (Buddhist monastic order) does wield influence as a result of it being the only institution, other than the Tatmadaw, that spans the entire country with its own internal communication and structure. ${ }^{250}$ Because the Sangha spirituality represents the majority of the population, entities that have the support of the Buddhist organisation are likely to be seen in a positive light, providing legitimacy to such entities. ${ }^{251}$ Buddhist monks have been at the forefront of political discontent, including in the 1988 and 2007 mass protests while supporting ASSK. ${ }^{252}$ This provides the NLD with a level of political legitimacy that the Tatmadaw, with its reliance on coercion, will never garnish. Religion is one aspect of the civil-military dynamic that the Tatmadaw has been unable to dominate.

\section{THE INTERNAL SECURITY FOCUS OF THE TATMADAW: 1948-2015}

This section seeks to understand how the Tatmadaw increased its political influence as a result of its focus on internal security. This section will argue that since 1948 the government has relied nearly exclusively on force to quell internal conflicts, only recently beginning to negotiate with ethnic groups. ${ }^{253}$ This heavy-handed approach has made the military politically influential because it has forcefully brought about political change while literally killing or imprisoning opponents; no other internal actor has the ability to physically force political change on such a scale as the Tatmadaw does. However, as a result of the Tatmadaw's use of violence to govern, which has resulted in human rights abuses, the

\footnotetext{
248 "Suu Kyi Cautions Myanmar not yet a Democracy," AFP News Agency, April 11, 2014, accessed October 29, 2015, www.youtube.com/watch?v=Kf ea36Bp3o.

${ }^{249}$ Elliot Brennan, "A New Wave of Violence and Buddhist Nationalism in Myanmar" Lowy Interpreter, January 28, 2015, accessed October 18, 2015, www.lowyinterpreter.org/post/2014/01/28/A-new-wave-of-violence-inMyanmar.aspx.; Bilveer Singh, "Religion as a Political ideology in Southeast Asia." in The Politics of Religion in South and Southeast Asia, ed. Ishtiaq Ahmed (Abingdon: Routledge, 2011), 130.

${ }^{250}$ Brennan, "A New Wave of Violence and Buddhist Nationalism in Myanmar:" Michael Fullilove, Andrew Selth and Sean Turnell, "Burma's Transition: Progress and Prospects", Lowy Institute for International Policy, Lowy Lecture Series, May 8, 2013, accessed October 19, 2015, www.vimeo.com/65777907.

${ }^{251}$ Singh, "Religion as a Political ideology in Southeast Asia," 130-131.

252 Ibid; Bruce Matthews, "The Legacy of Tradition and Authority: Buddhism and the Nation of Myanmar." in Buddhism and Politics in Twentieth Century Asia ed. Ian Harris (London: Continuum, 1999), 39-40.

${ }^{253}$ Callahan, "Burma: Soldiers as State Builders." 428.
} 
military has been pressured by internal and external actors to reform and has been increasingly viewed as an oppressive actor by much of the population.

The Tatmadaw view their primary mission as the non-disintegration of the country, a point codified in the 'Three Main National Causes,' non-disintegration of the Union, nondisintegration of national unity and perpetuation of national sovereignty. ${ }^{254}$ This has led the Tatmadaw to become involved in socio-political fields as well as the military realm. ${ }^{255}$ Since independence in 1948, the Tatmadaw has focused on internal security which has dominated Myanmar, especially in the border regions where the Bamar are not the majority, including Rakhine, Kachin, Shan, Kayah and Chin states (See Map 3). ${ }^{256}$ One conservative estimate found that there are approximately 100,000 armed militiamen under the command of nearly 40 non-state groups and organisations. ${ }^{257}$

Historically, the Tatmadaw argued that they were the only force capable of protecting the country from disintegration. ${ }^{258}$ The military felt they had a historical and moral obligation to protect the nation's sovereignty from internal factors. ${ }^{259}$ Typically these insurgencies are led by an ethnic based armed force, such as the United Wa State Army, the Shan State Army and the Kachin Independence Army. Most of these ethnically based groups support a political structure and administer a shadow government in their respective area. In October 2015, only a month before the elections, the Tatmadaw managed to sign ceasefire agreements with eight ethnic groups, including the Karen National Union and the Restoration Council of Shan State. ${ }^{260}$

The military has employed enemy-centric counterinsurgency tactics aimed at destroying the ethnic based groups, not trying to win the 'hearts and minds' of the population, something other counterinsurgency strategies emphasise. ${ }^{261}$ According to Harvard University's International Human Rights Clinic, military campaigns have seen the Tatmadaw commit human rights abuses on a vast and arguably institutional level, including

\footnotetext{
${ }^{254}$ Myoe, "The Military and Political Liberalisation in Myanmar." 60. 255 Ibid.

256 “Myanmar” Uppsala University Conflict Database, accessed October 18, 2015, www.ucdp.uu.se/gpdatabase/gpcountry.php?id=112\&regionSelect=7-Eastern Asia.

257 Myoe, "The Military and Political Liberalisation in Myanmar." 63.

${ }^{258}$ Chao-Tzang Yawnghwe, "Burma: The Depoliticization of the Political" in Political Legitimacy in Southeast Asia: The Quest for Moral Authority ed. Muthiah Alagappa (Stanford: Stanford University Press, 1995), 189. 259 Ibid.

${ }^{260}$ Lin Min Mang and Ye Mon, "As Ceasefire Signed, President Confident more Groups will join Nationwide Pact," Myanmar Times, October 15, 2015, accessed October 20, 2015, www.mmtimes.com/index.php/national-news/17020-president-says-confident-more-armed-groups-will-joinnationwide-ceasefire.html.

${ }^{261}$ David Kilcullen "Two School of Classical Counterinsurgency," Small Wars Journal, January 27, 2007, accessed October 18, 2015, www.smallwarsjournal.com/blog/two-schools-of-classical-counterinsgency.
} 
extrajudicial killings, sexual violence against women and girls, the recruitment of child soldiers, the use of landmines to inflict civilian casualties and indiscriminate artillery shelling. ${ }^{262}$ In recent years, the Tatmadaw has begun releasing child soldiers, the slowness of which is drawing criticism. ${ }^{263}$ The Tatmadaw's violent behaviour has understandably caused international condemnation on a number of occasions, as well as intense domestic scrutiny. ${ }^{264}$ Chao-Tzang Yawnghwe argues that the Tatmadaw's own legitimacy and credibility as patriotic institution has been gravely compromised as a result of its violent behaviour. ${ }^{265}$ This has changed the way much of the population view the military, including the Bamar. $^{266}$

\section{THE TATMADAW'S CORPORATE INTERESTS: 1948-2015}

With extra funding, both off-budget and on-budget, the military can do a number of things; it can provide extra wealth to its elite, it can buy new military capabilities, it can conduct operations as well as build national infrastructure. Historically, it was widely believed that the Tatmadaw controlled much of the natural resources and economy of Myanmar, providing it access to the riches of the state. ${ }^{267}$ Since 2011, this has changed significantly with the economy being opened up; the Tatmadaw has lost its dominating economic role. However, this is not necessarily a negative development for the military as the economy, now much larger, provides the Tatmadaw with an increased budget. This section seeks to understand the relationship between the Tatmadaw's corporate interests and the organisation's politically influential. This section will argue that the Tatmadaw's corporate ventures and dominance of the economy merely followed its trajectory as the country's dominant political actor. As such it is difficult to deduce that the Tatmadaw is more influential as a result of its corporate interests as it is the dominating entity.

\footnotetext{
262 International Human Rights Clinic (Harvard University), Policy Memorandum: Preventing Indiscriminate Attacks and Wilful Killings of Civilians by the Myanmar Military (Cambridge: Harvard University, 2014) quoted in Andrew D. Kaspar, "Report Says Tatmadaw's Targeting of Civilians 'Ongoing' Urges Reforms" Irrawaddy, March 24, 2014, accessed October 18, 2015 www.irrawaddy.org/burma/report-says-tatmadaws-targeting-ofcivilians-ongoing-uges-reforms.html.

263 John Zaw, “Myanmar's Army Releases 51 Child Soldiers," UCA News, June 5, 2015, accessed October 22, 2015, http://www.ucanews.com/news/myanmars-army-releases-51-child-soldiers/73734.

${ }^{264}$ Hunter Marston and Andrew Morgan, "Have Myanmar's Armed Forces Gone too Far?," Diplomat, April 8, 2015, accessed October 23, 2015, www.thediplomat.com/2015/04/have-myanmars-armed-forces-gone-too$\frac{\mathrm{far} / \text {. }}{265}$.

${ }^{265}$ Yawnghwe, "Burma: The Depoliticization of the Political." 189.

266 Ibid.

${ }^{267}$ Kai Chen, "Book Review: Mietzner, M (ed.) (2013). The Political Resurgence of the Military in Southeast Asia: Conflict and Leadership," Austrian Journal of South-East Asian Studies 7, no. 1: 138.
} 
Following the 1962 coup, the junta's so-called 'Burmese Way to Socialism' nationalised various enterprises in Myanmar, placing them under the control of Yangon; in effect, the Tatmadaw administered the majority of the economy. ${ }^{268}$ Individual army units also went into business, even though they were not legally entitled to do so. ${ }^{269}$ Unit level profits supposedly provided income to the respective regimental funds for the benefit of the unit's personnel and families. ${ }^{270}$ Units also leased out state-owned premises, on sold electricity and rented out military trucks for commercial purposes. ${ }^{271}$

Prior to the establishment of the current quasi-civilian government, the Tatmadaw dominated Myanmar's economy. Myanmar's Trade Council was run by the military and chaired by the army commander; no company could export of import without a permit from this council. ${ }^{272}$ Economic decision making was controlled by the regime, not by technocrats in the relevant civilian ministries. ${ }^{273}$ These factors have changed significantly in the quasicivilian era; the Trade Council has been abolished, the Tatmadaw's dominance of economic decision making has receded in favour of civilian technocrats, while military run businesses have all but a limited role.

In the junta era, the Tatmadaw received approximately a quarter of the total government budget, with the healthcare sector receiving less than two percent. ${ }^{274}$ Although the military's portion of the budget as of 2012-13 was reduced to 14.4 percent of the total government budget, the actual budgetary amount has increased by over 60 percent. ${ }^{275}$ As such, the military may see economic reform in a positive light, especially if their budget continues to increase as it has, something which is being forecasted. ${ }^{276}$

Corruption remains rife in Myanmar, which provides an alternate funding stream for Tatmadaw's elite. A still standing 1997 law orders Tatmadaw commanders to remain selfsufficient in their respective area of operation, pressuring commanders to establish their own business ventures. ${ }^{277}$ Conditions of employment for enlisted personnel are comparatively poor, with reports of soldiers having to purchase their own uniforms and equipment, and not

\footnotetext{
${ }^{268}$ Maung Aung Myoe, Building the Tatmadaw: Myanmar Armed Forces Since 1948 (Singapore: ISEAS, 2009), 174.

${ }^{269}$ Ibid.

${ }^{270}$ Ibid.

${ }^{271}$ Ibid.

272 “Myanmar's Military: Back to Barracks?," International Crisis Group: Update Briefing, Asia Briefing No. 143, April 22, 2014, 9.

${ }^{273}$ Ibid.

274 Brian McCartan, "Myanmar Military in the Money," Asia Times, February 28, 2012, accessed October 20, 2015, www.atimes.com/atimes/Southeast Asia/NB28Ae02.html.

${ }^{275}$ Ibid.

${ }^{276}$ Ibid.

${ }^{277}$ Ibid.
} 
being remunerated sufficiently to feed their families. ${ }^{278}$ As a result of austere conditions, it is safe to say that enlisted personnel may be pressured into more coercive and corrupt means of generating income. A 2015 Environmental Investigation Agency report noted how Chinese nationals, illegally conducting logging in Myanmar, are sometimes captured by Tatmadaw personnel and released only after their Chinese employer pays upwards of USD $\$ 7,800 .{ }^{279}$ It is impossible to fully understand the extent of corruption in Myanmar, but it is suffice to say that the country is consistently ranked as one of the most corrupt countries in the world by international watchdogs such as Transparency International. ${ }^{280}$

The ability of a military to raise off budget funds may provide it options to use those funds how it sees fit. This creates a capacity to bring about political ends that it would otherwise not be able to control through the central government's budget. Although, the Tatmadaw does have significant economic holdings and control over some of the natural resources of the state, it is difficult to deduce how it would increase its political influence as a result of its corporate interests; this is simply because the Tatmadaw already dominates the political structure. How could the Tatmadaw actually gain more influence if it is already by far the most dominating political institution?

\footnotetext{
278 McCartan, "Myanmar Military in the Money."

${ }^{279}$ Environmental Investigation Agency, Organised Chaos: The Illicit Overland Timber Trade between Myanmar and China, (London: Environmental Investigation Agency, September 2015) 9.

${ }^{280}$ McCartan, "Myanmar Military in the Money."
} 


\title{
PART TWO: ASSESSMENT - THE POLITICAL INFLUENCE OF THE TATMADAW IN A DEMOCRATIC MYANMAR
}

\author{
"As we mature in democracy in our country, the role of the military \\ in parliament will reduce gradually."281 \\ President Thein Sein, 2015
}

Unlike the second part on Indonesia, this section can not describe the current-state of the military's political influence in a democratic Myanmar. The reason why is quite simple; Myanmar is yet to realise democracy. So-called 'Burma Watches' agree that although Myanmar has come a long way since 2011, when the junta established a new quasi-civilian government, reform has largely stagnated. Andrew Selth illustrates this point with his review of the 2015 Myanmar/Burma Update, a regular Australian National University conference on Burmese studies; "most speakers at the ANU conference presented sobering accounts of the obstacles facing democratisation in Burma and the likely pace of reform over the next few years." 282

As these actions and decisions are yet to be made, there is a requirement for future assessments to be produced. It should be stressed that there are major limits to futurist thinking. This section will use the findings of this paper to produce assessments on the Tatmadaw's political influence in a future democratic Myanmar. It is impossible for any future assessment to be fully accurate. This is because there are so many variables and conditions that are yet to be fully realised or understood, while many decisions have not yet been made. However, quality assessments of likely and unlikely courses of action can be produced with knowledge of historical and contemporary issues based around a structured analytical framework. Unlike other sections, this assessment will employ an analytical framework referred to as the cone of plausibility.

\footnotetext{
${ }^{281}$ Jonah Fisher, "Thein Sein: Myanmar Army to Continue Key Transition Role," BBC, March 20, 2015, accessed April 27, 2015, http://www.bbc.com/news/world-asia-31957685.

${ }^{282}$ Andrew Selth, "Burma: Beware of Unrealistic Expectations" Lowy Interpreter, June 18, 2015, accessed October 29, 2015, www.lowyinterpreter.org/author/Andrew\%Selth.aspx.
} 
The cone of plausibility is an analytical method of plotting future plausible scenarios of a given issue or topic in a logical manner. ${ }^{283}$ As this paper has three main CMR themes, three cones have been produced to assist in producing overall indicators of the future of Myanmar's civil-military dynamic (See Annexes one through three). Each cone produces three plausible scenarios for the given theme; providing a most likely course of action (Baseline Scenario), a secondary likely course of action (Alternative Scenario) and a third plausible but unlikely scenario (Wildcard Scenario). The first step in producing a cone is anchoring the scenarios with a date in the future. After the date has been decided, drivers that assist in explaining the theme are brainstormed with knowledge of the subject. Once all the drivers have been listed, plausible judgements, referred to as assumptions, are made for each theme. The culminating effect of the assumptions produces the Baseline Scenario. To make the Alternative Scenario, the assumption that is judged most likely to change in the given timeframe is altered, changing the Baseline Scenario. To make the Wildcard Scenario, the assumption that is judged the least likely to change is altered, again providing a different course of action. To help visualise the cone of plausibility methodology, review annexes one through three.

Given Myanmar's 2008 Constitution states that elections take place every five years, and elections are to be conducted in November 2015, this section employs the future date of 2021 to anchor all assessed courses of action to the same timeframe. Analysis of Myanmar's experience in part one of this chapter produces the raw drivers for each of the three cones. Each assumption provides the most likely development of the respective driver given knowledge of contemporary and historical issues of the theme, coupled with a limited cultural understanding of the chaotic plethora of Burmese cultures. For the purposes of analytical credibility, this section accepts that certain conscious and unconscious assumptions have been made. These include but are not limited to the following;

- Free and fair elections will be conducted in November 2015.

- The NLD will win the 2015 elections but ASSK will not become president.

- The Tatmadaw will not conduct a coup immediately after the November 2015 elections.

- The constitution will remain largely intact, resulting in strong Tatmadaw representation in the Pyidaungsu Hluttaw.

- Foreign intervention into Myanmar is unlikely.

- Internal conflict will remain a serious issue.

- No major civil backlash will occur as a result of the fact that ASSK can not become president.

\footnotetext{
${ }^{283}$ For a methodological review of the cone of plausibility see Charles W. Taylor, Creating Strategic Visions (Carlisle: Strategic Studies Institute, U.S. Army War College, 1990), 12-16; Charles W. Taylor, "Projecting the Changing Conflict Setting," in Special Operations Forces: Roles and Missions in the Aftermath of the Cold War, eds. Richard H. Schultz, Jr., Robert L. Pfaltzgraff, Jr., W. Bradley Stock (Collingdale: Diane Publishing, 1995$), 53$.
} 
As well as assumptions, it should be emphasised that certain biases and predispositions have effected the following assessments. The most obvious bias made is referred to as 'mirror-imaging' which is a natural tendency to underestimate the differences between one's culture and the society with which is being analysed. This is important because the author of this paper was raised in a Western democracy and has a number of predispositions toward emotive concepts such as human rights, law, freedom, conflict, religion, justice and democracy; concepts that may be perceived very differently in Burmese culture.

\section{THE WEAKNESS OF CIVILIAN INSTITUTIONS AND THE INVOLVEMENT OF THE TATMADAW IN POLITICS IN A DEMOCRATIC MYANMAR}

This section provides three plausible assessments on the weakness of civilian institutions and the involvement of the Tatmadaw in politics in a future democratic Myanmar. Following is a table that represents the baseline drivers and assumptions;

TABLE 2: Drivers and Assumptions - The Weakness of Civilian Institutions and the Involvement of the Tatmadaw in Politics in a Democratic Myanmar

\begin{tabular}{|l|l|}
\hline DRIVERS & ASSUMPTIONS \\
\hline $\begin{array}{l}\text { Civilian Leaders } \\
\text { and Institutions }\end{array}$ & $\begin{array}{l}\text { Civilian leaders and institutions will struggle in the early years of democratic } \\
\text { transition as a result of the inherent weakness of young and underdeveloped } \\
\text { institutions which are for the most part still finding their feet. }\end{array}$ \\
\hline $\begin{array}{l}\text { Retired } \\
\text { Tatmadaw } \\
\text { Officers }\end{array}$ & $\begin{array}{l}\text { As a result of their management experience, retired Tatmadaw officers will } \\
\text { remain influential, including in parliament where they will continue to take up } \\
\text { various leadership roles, such as speakerships. }\end{array}$ \\
\hline $\begin{array}{l}\text { Parliamentary } \\
\text { Representation } \\
\text { and the 2008 } \\
\text { Constitution }\end{array}$ & $\begin{array}{l}\text { The 2008 Constitution will remain largely unchanged. Minor changes will see the } \\
\text { Tatmadaw lose a small portion of their share (25 percent) of the seats in the } \\
\text { Pyidaungsu Hluttaw. The military will not allow ASSK to become president. }\end{array}$ \\
\hline $\begin{array}{l}\text { Tatmadaw } \\
\text { Leadership's view } \\
\text { of Democracy }\end{array}$ & $\begin{array}{l}\text { The Tatmadaw's leadership want democracy to flourish. However, the military } \\
\text { only cede control of the country on their own terms. One of the main terms will be } \\
\text { the protection of the leadership's private interests. As such, civilian leaders will } \\
\text { have to compromise with the Tatmadaw, providing the military with concessions; } \\
\text { military leaders involved in past human rights abuses will not be brought to justice } \\
\text { while their accumulated wealth will largely be untouched. }\end{array}$ \\
\hline $\begin{array}{l}\text { Internal Conflict } \\
\text { and the } \\
\text { Tatmadaw's }\end{array}$ & $\begin{array}{l}\text { Although the democratically elected government will push for the peaceful } \\
\text { resolution of the various civil wars with Myanmar's ethnic based groups, armed } \\
\text { conflict will remain a serious issue in the country. As a result, the Tatmadaw will }\end{array}$ \\
\hline
\end{tabular}


Stabilising Effect

remain internally focused and will retain a strong raison d'être, providing a

justification for it's self-perception as a sole protector of the Three Main National

Causes.

\section{BASELINE SCENARIO - COURSE OF ACTION ONE}

The culminating effect of the six baseline assumptions is that; Tatmadaw's leadership accepts democratic transition albeit only on its own terms. As such, civilian leaders, who remain relatively weak, compromise with the Tatmadaw. One of the main terms is that the private interests of Tatmadaw leaders are protected; military leaders involved in human rights abuses are not prosecuted while their accumulated wealth is protected. The Tatmadaw retains a limited share of seats in the Pyidaungsu Hluttaw. The USDP also loses seats in parliament. Although the democratically elected government pushes for the peaceful resolution of the various internal conflicts between the central government and ethnic based groups, civil war remains a serious issue in Myanmar. As a result, the Tatmadaw will remain internally focused and will retain a strong raison d'être, providing a justification for it's selfperception as a sole protector of the Three Main National Causes. The Tatmadaw continue to hold significant political clout but accept civilian democracy on their own terms.

\section{ALTERNATIVE SCENARIO - COURSE OF ACTION TWO}

The most likely assumption to change is; the Tatmadaw Leadership's view of Democracy. This is because with the increased international and domestic pressure, the Tatmadaw is likely to make at least limited concessions to civilian leaders by 2021 . The changed assumption is that; although the Tatmadaw still want democracy, they are not yet willing to cede control to civilian elected leaders. This produces the following assessment;

Tatmadaw's leadership refuse democratic transition. The Tatmadaw retains 25 percent of the seats in the Pyidaungsu Hluttaw. Even though civilian parties have a majority of the parliament, the veto available to the Tatmadaw, stagnates political reform. Although the democratically elected government push for the peaceful resolution of the various internal conflicts between the central government and ethnic based groups, civil war remains a serious issue in Myanmar. As a result, the Tatmadaw will remain internally focused and will retain a strong raison d'être, providing a justification for it's self-perception as a sole protector of the Three Main National Causes. The Tatmadaw continues to be the most politically influential actor in Myanmar. 


\section{WILDCARD - COURSE OF ACTION THREE}

The least likely assumption to change is; Internal Conflict and the Tatmadaw's Stabilising Effect. Internal conflict between ethnic groups has been commonplace in Myanmar throughout its history. Although there have been recent ceasefire treaties agreed to, the dominance of the Bamar in the NLD and the Tatmadaw, as well as other institutions, is a core reason why internal conflict remains a serious issue in Myanmar. The changed assessment is that; civilian parties agree with most ethnic based groups to cease conflict which changes the perception of the Tatmadaw. The Three Main National Causes are no longer so important. This produces the following assessment;

The Tatmadaw accept democracy under its own terms but retain a limited share of seats in the Pyidaungsu Hluttaw. Civilian leaders, who remain relatively weak, compromise with the Tatmadaw. One of the main terms is that the private interests of Tatmadaw leaders are protected; military leaders involved in human rights abuses are not prosecuted while their accumulated wealth is protected. The USDP also lose seats in parliament. The democratically elected government pushes for the peaceful resolution of the various internal conflicts which produces the desired outcome; most ethnic groups agree to a cessation of hostiles. As a result, the Tatmadaw loses its a strong raison d'être, significantly downgrading its justification for its own self-perception as a sole protector of the Three Main National Causes. The Tatmadaw continue to hold political clout but accept civilian democracy on their terms. The military lose influence.

\section{CONCLUSION}

These three assessed scenarios illustrate one major point; the Tatmadaw has the power to decide whether or not Myanmar will become a democracy; civilians have little say. The real power is with the Tatmadaw's leadership. It was assessed that they would only cede control of the country to democratically elected civilians under their own conditions. It is very likely that the Tatmadaw will retain significant influence in the democratic era, especially in the first years while civilian institutions remain underdeveloped. 


\section{THE INTERNAL SECURITY FOCUS OF THE TATMADAW}

This section provides three plausible scenarios on the internal security focus of the Tatmadaw in a future democratic Myanmar and its effect on the military's political influence. Following is a table that represents the baseline drivers and assumptions;

TABLE 3: Drivers and Assumptions - The Internal Security Focus of the Tatmadaw in a Democratic Myanmar

\begin{tabular}{|l|l|}
\hline DRIVERS & ASSUMPTIONS \\
\hline $\begin{array}{l}\text { Diversity of Myanmar and } \\
\text { Bamar }\end{array}$ & $\begin{array}{l}\text { Myanmar obviously continues to be an ethnographically complex } \\
\text { country. The Bamar continue to dominate Burmese society, } \\
\text { perpetuating issues with other ethnic groups. }\end{array}$ \\
\hline Buddism & $\begin{array}{l}\text { Buddhist groups continue to back civilian political leaders and lead } \\
\text { protests against the military's political role. }\end{array}$ \\
\hline $\begin{array}{l}\text { Tatmadaw's Reliance on } \\
\text { Coercion }\end{array}$ & $\begin{array}{l}\text { In the face of heavy domestic and international criticism, the Tatmadaw } \\
\text { slightly reduce their heavy reliance on coercion to deal with ethnic } \\
\text { groups and protestors. However, the military still conduct enemy-centric } \\
\text { counterinsurgency operations against the ethnic based groups which } \\
\text { sees various human rights abuses committed. }\end{array}$ \\
\hline $\begin{array}{l}\text { Internal vs. External Focus } \\
\text { of the Tatmadaw }\end{array}$ & $\begin{array}{l}\text { The Tatmadaw will become more focused on external defence than it } \\
\text { was in the past. This is a result of the changing geopolitical } \\
\text { environment in the Indo-Pacific region. Myanmar will seek to have close } \\
\text { relations with most regional countries, including China and the U.S. The } \\
\text { Tatmadaw will still focus most of its attention on internal security. }\end{array}$ \\
\hline $\begin{array}{l}\text { Ceasefire Agreements and } \\
\text { Subsequent Cessation of } \\
\text { Hostilities }\end{array}$ & $\begin{array}{l}\text { Naypyidaw does not successfully complete signing ceasefire } \\
\text { agreements with all ethnic groups which sees a continuation of conflict. }\end{array}$ \\
\hline
\end{tabular}

\section{BASELINE SCENARIO - COURSE OF ACTION ONE}

The culminating effect of the six baseline assumptions is that; the central government fails to agree with all ethnic groups on the caseation of hostiles throughout the country. This sees the perpetuation of the Tatmadaw's focus on internal security; however, due to increasing interest from international actors, as well as the speed with which information is now disseminated, the Tatmadaw reduce their level of violence. Political protests continue in the major urban areas, at times instigated by Buddist groups wishing to bring about change. Human rights abuses still occur but on a reduced scale and intensity. The Tatmadaw begin to focus more attention and resources to external defence, and the capabilities required for such operations, such as naval and air assets. The military continue to derive political 
influence from their involvement in internal security as they remain the sole national organisation capable of physically bringing about political change at the national level.

\section{ALTERNATIVE SCENARIO - COURSE OF ACTION TWO}

The most likely assumption to change is; the ceasefire agreements and subsequent cessation of hostiles. This is only the most likely as a process of elimination; it is very difficult to see how the other assumptions made are likely. The changed assumption is that;

The central government, through concessions, manage to agree to a caseation of all hostilities with ethnic based groups. This has the effect of representing the aspirations of the non-Bamar minorities, ceding some control of certain areas, similar to the way Aceh Province is administered in Indonesia. This has greatly reduced the requirement to have an internally focused military. This reduces the political clout of the military as they are no longer required on such a scale as they were earlier.

\section{'WILDCARD' - COURSE OF ACTION THREE}

The least likely assumption to change is; Buddhist groups continue to back civilian political leaders and lead protests against the military's political role. This is the most unlikely as the Buddhists have remained firmly anti-junta for the past 50 years. Their belief in nonviolent political change is also in line with the country's most popular civilian party, the NLD. The changed assumption is; As a result of the religious leaders quest for stability, Buddhist groups back the military in retaining a strong political orientation. This produces the following assessment;

The central government fail to sign peace agreements with all ethnic based groups. Buddhist groups back the military's strong political orientation which results in much of the Bamar population rallying behind the military in the fight against the disparate ethnic based groups. This sees the Tatmadaw focusing on areas with large Muslim concentrations, such as Rakhine State. The military's level of brutality increases as a result of their domestic acceptance. The military remain deployed throughout the country. Their level of political influence increases as the civilian government now requires the military to be engaged across the country. Economic sanctions from Western countries are again placed on Myanmar.

\section{CONCLUSION}

It is difficult to imagine a Myanmar without ethnic based groups and the continuation of violence. The central government will have to make concessions to groups that remain 
unwilling to cease hostilities. Buddhist groups will likely remain influential. Violence will likely continue in the northern and western states, including Rakhine, Kachin and Shan. As a result of the continuation of violence, the Tatmadaw will likely remain critical to the central government's cause and thus influential.

\section{THE TATMADAW'S CORPORATE INTERESTS}

This section seeks to assess the possibility of the Tatmadaw gaining or losing political influence in a future democratic Myanmar as a result of its corporate interests. Following is a table that represents the assessed baseline drivers and assumptions for this topic;

TABLE 4: Drivers and Assumptions - The Weakness of Civilian Institutions and the Involvement of the Tatmadaw in Politics in a Democratic Myanmar

\begin{tabular}{|l|l|}
\hline DRIVERS & ASSUMPTIONS \\
\hline Relationship & $\begin{array}{l}\text { The Tatmadaw will accept the democratically elected civilian } \\
\text { government and thus accept civilian control of the military. However, } \\
\text { the military will still hold politician clout with a reduced amount of seats } \\
\text { in parliament, down from } 25 \text { percent. The USDP will also have far less } \\
\text { seats in both the upper and lower houses of the Pyidaungsu Hluttaw. }\end{array}$ \\
\hline The Defence Budget & $\begin{array}{l}\text { The defence budget will remain relatively high at between 10 percent } \\
\text { and } 14.4 \text { percent. Much of the budget will be spent modernising the } \\
\text { Tatmadaw's capabilities. }\end{array}$ \\
\hline Corruption & $\begin{array}{l}\text { Corruption will remain rife within Burmese culture, providing Tatmadaw } \\
\text { commanders access to an alternate funding stream. }\end{array}$ \\
\hline Economic Development & $\begin{array}{l}\text { Myanmar's economy will continue to grow exponentially providing a } \\
\text { much larger total government budget to the civilian government. As } \\
\text { such, the government can provide the military with an increased total } \\
\text { budget, even if the proportion reduces from around 14 percent to } \\
\text { around 10 percent. }\end{array}$ \\
\hline $\begin{array}{l}\text { Solider Welfare/Unit } \\
\text { Requirements }\end{array}$ & $\begin{array}{l}\text { Individual units, particularly in remote border regions, will maintain } \\
\text { enterprises to supplement their portion of the central government's } \\
\text { defence budget. }\end{array}$ \\
\hline Interests. & $\begin{array}{l}\text { The military's foundations (UMEHL and MEC) will struggle to cope with } \\
\text { the very different political conditions of the democratic era while many } \\
\text { other actors vye for the same resources. }\end{array}$ \\
\hline
\end{tabular}




\section{BASELINE SCENARIO - COURSE OF ACTION ONE}

The culminating effect of the six baseline assumptions is that; the Tatmadaw accepts civilian hegemony while maintaining a reduced political capacity. The military receives a reduced percentage of the total budget. However, because the total amount of the budget has significantly increased, the Tatmadaw end up with an overall increased total amount. The military's business ventures struggle to cope with the onset of economic development, which has seen international interest in Myanmar increase exponentially. Individual military units continue to produce modest supplementary income for the benefit of members, namely their elite. Corruption provides the most obvious means with which these individual units can procure additional income.

\section{ALTERNATIVE SCENARIO - COURSE OF ACTION TWO}

It is most likely that the assessed defence budget will change before any of the other assumptions. Therefore, the altered assumption is that; the Tatmadaw's budget is significantly decreased to below five percent of the total government budget. Therefore, the alternative scenario is that;

Although the Tatmadaw accepts civilian control of the military, it intensifies it's legal and illegal business ventures to produce an increased budget. As the military's legitimate business ventures struggle to cope with the onset of economic development, the most obvious means with which the Tatmadaw can produce significant off-budget funds is exploitation of the mineral and forestry resources in the central and frontier regions. Corruption provides another obvious means with which individual units can procure additional modest income. The Tatmadaw increases its political influence as a result of a renewed economic focus which provides it with increased financial independence of the central government.

\section{'WILDCARD' - COURSE OF ACTION THREE}

It was found that the least likely assumption to change was Myanmar's GDP growth forecast, which is set to grow from USD $\$ 64.33$ billion in 2015 to USD $\$ 95.96$ billion by $2020 .^{284}$ The altered assumption is that Myanmar's GDP stagnates and recedes well below USD $\$ 64.33$ billion per annum. The wildcard scenario is that:

The Tatmadaw declines elected civilian governance and implants itself as a caretaker government while it intensifies its economic enterprises, nationalising various industries. This sees a dramatic shift in Myanmar's foreign policy as Western sanctions intensify. This

\footnotetext{
${ }^{284}$ Myanmar Economic Forecasts: 2015-2020 Outlook," Trading Economics, accessed October 25, 2015, www.tradingeconomics.com/myanmar/forecast.
} 
pushes Myanmar closer to China, Russia and other non-Western powerbrokers. In this scenario, the Tatmadaw gains political influence because it becomes the governing institution, not because of corporate interest but because of brute force.

\section{CONCLUSION}

In the pre-democratic analysis of this topic, it was difficult to understand how the most politically influential organisation in the country could possibly acquire more influence through its corporate interests. This is because of the way political influence is derived from the corporate sector; financial independence increases the political influence of the military and limits the ability of the central government to oversee the military's activities. Having the ability to fund initiatives that the civilian government has not budgeted for, allows the military to bypass civilian policy processes and make decisions that may run counter to the interests of the government. ${ }^{285}$ The most plausible future scenario found that even with a seriously reduced level of involvement in the economic sector, it is plausible that the Tatmadaw will retain some influence as a result of its likely perpetuation of certain economic endeavours. This is because the military will no longer be the most powerful political actor, but subordinate to the civilian government.

\section{CONCLUSION OF CHAPTER THREE}

Part one of this chapter sought to understand the extent of the Tatmadaw's political influence. The first section illustrated how the Tatmadaw became involved in politics in the first place and how it rose to become the most dominant actor in Myanmar. Although recent reforms are viewed positively, it should be remembered that running up to the November 2015 elections, the Tatmadaw is the most politically influential actor in Myanmar, with a significant share (25 percent) of the seats in the Pyidaungsu Hluttaw, and a dominant role in the governance of the ruling party, the USDP. The seats in the Pyidaungsu Hluttaw give the Tatmadaw an effective veto over other political actors, as a result of their strong standing in the 2008 Constitution which states that 75 percent of the Pyithu Hluttaw must agree to any constitutional change. Although the NLD is the most dominant party in Myanmar, it remains institutionally weak as a result of it having all of its leadership eggs (ASSK) in one basket. ${ }^{286}$ The second section showed how over the past five decades the Tatmadaw has ruled over Myanmar and been the most politically influential force in the country largely as a result of its capability to conduct violence. As a result of its overreliance on coercion, the Tatmadaw has

\footnotetext{
${ }^{285}$ Mietzner and Misol, "Military Businesses in post-Suharto Indonesia: Decline, Reform and Persistence." 101.

${ }^{286}$ Lee Jones, Societies under Siege: Exploring How International Economic Sanctions (Do Not) Work (Oxford: Oxford University Press, 2015), 101-102; Nicholas Farrelly, "NLD needs to Lift the Standard," New Mandala, September 21, 2015, accessed October 18, 2015, www.asiapacific.anu.edu.au/newmandala/2015/09/23/nldneeds-to-lift-the-standard/.
} 
arguably lost much of its domestic legitimacy and credibility as a so-called patriotic institution, a concept it regards as important. ${ }^{287}$ The Tatmadaw have created a paradox in that it can only safeguard the nation by harassment and coercion of the population. ${ }^{288}$ The third section showed that as the most dominant political entity in Myanmar, it is somewhat difficult to understand how the Tatmadaw could garnish more political clout as a result of its corporate interests. The culminating effect of this part is that without the military's approval to change the constitution, Myanmar will remain a military-run state. Civilians have very little say in the matter.

The second part of this chapter noted that because Myanmar is yet to relaise democracy, future judgements were required to answer the Myanmar 'part' of the core question of this paper. This part used an analytical method refereed to as the cone of plausibility to help shed light on plausible scenarios. From the scenarios generated certain themes emerged. Informed judgements can be made from these themes. The first section reinforced the findings from the previous section, noting that the Tatmadaw has the power to decide whether or not Myanmar will become a democracy; civilians have little say. The real power is with the Tatmadaw's leadership. It was assessed that they would only cede control of the country to democratically elected civilians under their own conditions. The Tatmadaw is unlikely to cede all of its seats in the Pyidaungsu Hluttaw by 2021. It is very likely that the Tatmadaw will retain significant influence in the democratic era, especially in the first years while civilian institutions remain underdeveloped. The second section found that for the Tatmadaw to lose its strong internal security focus, any democratic government would have to peacefully conclude the majority of armed conflicts throughout the country. This can only occur when the government accepts that certain concessions will have to be provided to the ethnic groups in order to halt the fighting. Due to the likelihood in the continuation of violence, the Tatmadaw will also remain critical to the central government's cause and thus influential. The third section of this part showed that in a democratic Myanmar, the Tatmadaw may in fact derive influence from its corporate interests. This was difficult to realise in the pre-democratic era as the Tatmadaw was already the most politically influential actor in the country and could not acquire more influence.

\footnotetext{
${ }^{287}$ Jones, Societies under Siege: Exploring How International Economic Sanctions (Do Not) Work, 101-102; Farrelly, "NLD needs to Lift the Standard."

${ }^{288}$ Nyein, "The Armed Forces of Burma." 24.
} 


\section{CONCLUSION}

This paper has sought to answer the following question; to what extent has the TNI lost political influence in the democratic era and are similar developments likely for Myanmar's Tatmadaw? Chapter one reviewed literature on the theories of influence, democracy and CMR, focusing on Southeast Asian approaches. This chapter produced a framework that was used for further analysis on Indonesia and Myanmar. The framework was made up of three key arguments, which were originally presented by Alagappa and Mietzner, that help explain the political influence of the military. The framework's first point argued the most important way militaries can gain influence is by becoming involved in the political institutions of the state, while civilians remain weak. The second part of the framework was derived from Alagappa's core thesis argument on the utility of coercion in governance. This states that, although coercion and domestic political legitimacy are negatively related, coercion does make a military influential as it is able to forcefully bring about political ends. The last part of the framework noted that the military will likely assume a greater role in the corporate world if its governance role is expanded, which subsequently expands the political influence of the military further. By having its own income sources, the military can limit the oversight and influence that a civilian government has over it, increasing the military's autonomy as a political actor.

Chapter two focused on the Indonesian experience and concluded that although the TNI has lost significant political influence in the democratic era, it remains politically orientated. A comparison between the pre-democracy and democratic periods found that the TNI was historically the most politically influential actor in Indonesian politics. In the democratic era, however, this has changed significantly with the military no longer as influential as it once was. This loss of influence is visible in that the TNI no longer have seats in the MPR, nor does it have official links with any party, factors which directly limits its ability to bring about political change. The TNl's self-induced 'New Paradigm', an aspect of reformasi, also split the military and the police and shelved the dwi-fungsi doctrine, reform measures that are in line with democratic CMR. However, the TNI seems to be interested in retaining a strong internal role, jostling with the newly-formed POLRI for primacy of the internal security domain. This has seen the TNI and POLRI compete for the country's high profile counterterrorism job. For Indonesia to consolidate as a democracy, it must find ways to limit the TNl's internal security role. The military may continue to have a small part to play in internal security, especially in the higher end of the threat spectrum, but there is a very fine line. The TNI's retention of the TCS and its ability to project force internally still provides the military influence throughout the country. The TNl's corporate interests have been hit 
hard by democratic transition, which has seen very different economic conditions eventuate. In the pre-democratic period, the TNI was given nearly unlimited access to the riches of the state. In the democratic era, the TNI is merely one of many actors trying to profit from the mineral rich country. The TNI's modest ability to create off-budget funds enables a level of autonomy from central government. This was even the case during the New Order, when the TNI and Suharto were in close association. It was found that in 2010 a major-Western mining consortium paid the TNI and POLRI approximately USD\$14 million for security of sites in Irian Jaya. Does this money go into the state coffers or into the (big) pockets of local TNI commanders? This is difficult to assess. The fact is, in the democratic era, the TNI is still engaged in profiteering which provides it autonomy from the central government, which is inherently undemocratic.

Chapter three found that Myanmar and Indonesia do have CMR traits in common, including the militaries dominant role since independence in the 1940s. The first part of the chapter on Myanmar discussed the rise of the military's political role since independence until immediately prior to the 2015 election. This part found that the Tatmadaw effectively became the government in 1958 and largely retained that role until 2011 when the current quasi-civilian government was established. The Tatmadaw's internal security focus, which has seen a heavy-handed approach involving various human rights violations, resulting in the Tatmadaw's own legitimacy and credibility as a self-perceived patriotic institution compromised. ${ }^{289}$ This has changed the way much of the population view the military, including the majority Bamar. ${ }^{290}$ The current quasi-civilian government is dominated by retired and current serving military personnel. As well as dominating the ruling party, the USDP, the Tatmadaw has 25 percent of the seats in the Pyidaungsu Hluttaw. The military has engineered its longevity through the 2008 Constitution, which states that any constitutional change require 75 percent of the Pyidaungsu Hluttaw to concur, something nearly impossible without the approval of the Tatmadaw; this gives the military a veto option. The second part of the chapter on Myanmar sought to produce insights into the likely political influence of the Tatmadaw in a future democratic Myanmar. The cone of plausibility was used to produce scenarios that insights could be extracted from. This method assessed that the Tatmadaw is likely to remain politically influential in a future democratic Myanmar, similar to the way the TNI has positioned itself in post-Suharto Indonesia. The weakness of civilian institutions will remain for years to come in Myanmar. This will likely include the NLD, which as of 2015, has a weak institutional structure as a result of having all of its leadership eggs in one basket, ASSK. Being the main political party challenging the Tatmadaw's

\footnotetext{
${ }^{289}$ Yawnghwe, "Burma: The Depoliticization of the Political." 189.

${ }^{290}$ Ibid.
} 
continued dominance; the NLD will require a diversification of its leadership if it is serious about replacing the quasi-civilian government in the coming years. Even in a democratic Myanmar, it is unlikely the Tatmadaw will give up its entire seating arrangement in the Pyidaungsu Hluttaw. Again, this will ensure a continuation of direct influence in parliament. Armed conflict is likely to remain a serious issue for Myanmar which is also likely to see the Tatmadaw remain politically influential as it will remain critical to the central government's causes. The Tatmadaw's corporate interests may provide it influence in a future democracy as profits will enable the military to fund their own initiatives. It was impossible to realise how this could occur in pre-democratic Myanmar as the military was already the most influential organisation. This paper has shown that the Tatmadaw will very likely remain politically motivated and politically orientated in a future democratic Myanmar, much like the TNI has. It should be reemphasised that assessments made herein are just that; assessments. Only time will tell how the Tatmadaw will react to democratic transition. 


\section{BIBLIOGRAPHY}

"Burma." Central Intelligence Agency World Factbook. Accessed October 19, 2015. www.cia.gov/library/publications/the-world-factbook/.../bm.html.

"Myanmar Economic Forecasts: 2015-2020 Outlook." Trading Economics. Accessed October 25, 2015. www.tradingeconomics.com/myanmar/forecast.

"Myanmar." Uppsala University Conflict Database. Accessed October 18, 2015. www.ucdp.uu.se/gpdatabase/gpcountry.php?id=112\&regionSelect=7-Eastern Asia.

"Suu Kyi Cautions Myanmar not yet a Democracy." AFP News Agency, April 11, 2014. Accessed October 29, 2015. www.youtube.com/watch?v=Kf ea36Bp3o.

"The Square Mile: After Years of Stagnation, Myanmar's Biggest City is Developing at Last." Economist, January 31, 2015. Accessed October 19, 2015. www.economist.com/news/asia/21641296-after-years-stagnation-myanmar-biggest-citydeveloping-last-square-mile.

"Timeline: Reforms in Myanmar," BBC News, July 8, 2015. Accessed October 12, 2015. www.bbc.com/news/world-asia-16546688.

"US Inflation Calculator." US Inflation Calculator. Accessed October 23, 2015. www.usinflationcalculator.com.

"World Fact Book: Indonesia." Central Intelligence Agency. Accessed September 23, 2015. www.cia.gov/library/publications/the-world-factbook/geos/id.html.

$A B C$ News, "Boxing Day Tsunami: How the Disaster Unfolded 10 Years Ago." December 24, 2014. Accessed October 7, 2015. www.abc.net.au/news/2014-12-24/boxing -day-tsunamihow-the-disater-unfolded/5977568.

Abrahamsson, Bengt. Military Professionalization and Political Power. Beverly Hills: Sage Publications, 1972.

Alagappa, Muthiah. Coercion and Governance: The Declining Role of the Military in Asia. Stanford: Stanford University Press, 2001.

Anaud, Brigadier (Rtd.) Vinod. "The Role of Myanmar's Military in Democratic Transition and Implications for India." Vivekananda International Foundation, Occasional Paper, December, 2013.

Anwar, Dewi Fortuna. Indonesia in ASEAN: Foreign Policy and Regionalism. Singapore: Institute of Southeast Asian Studies, 1994.

Bahruddin, Z B. "Plight of Rohingya People Goes International as Myanmar Reforms Stagnate." Asian Defence Journal, December, 2014, 4-5.

Baker, Jacqui. “Jokowi's Police go Unpoliced." East-West Forum, May 4, 2015. Accessed October 3, 2015. www.eastwestforum.org/2015/05/04/jokowis-police-go-unpoliced/.

Ball, Nicole. "Democratic Governance and the Security Sector in Conflict-Affected Countries." In Governance in Post-Conflict Societies: Rebuilding Fragile States, edited by Derick W. Brinkerhoff, 85-112. Abingdon: Routledge, 2007. 
Banfield, Edward C. Political Influence. New Brunswick: Transaction Publishers, 2003.

BBC, "The 12 October 2-2 Bali Bombing Plot." October 11, 2012. Accessed October 15, 2015, www.bbc.com/news/world-asia-19881138.

Beech, Hannah. "A New Hope: Indonesian President Joko Widodo is a Force for Democracy." Time, October 27, 2014, 22-25.

Brennan, Elliot. "A New Wave of Violence and Buddhist Nationalism in Myanmar." Lowy Institute for International Policy, Lowy Interpreter, January 28, 2015. Accessed October 18, 2015, www.lowyinterpreter.org/post/2014/01/28/A-new-wave-of-violence-in-Myanmar.aspx.

Browne, Susan M. "War-Making and U.S. State Formation: Mobilization, Demobilization, and the Inherent Ambiguities of Federalism." In Irregular Armed Forces and their Role in Politics and State Formation, edited by Diane E. Davis and Anthony W. Pereira, 232-252. New York: Cambridge University Press, 2003.

Bruneau, Thomas C. "Impediments to the Accurate Conceptualization of Civil Military Relations." In The Routledge Handbook of Civil-Military Relations, edited by Thomas C. Bruneau and Florina Cristiana Matei, 13-21. New York: Routledge, 2013.

Burk, James. "Theories of Democratic Civil Military Relations." Armed Forces \& Society 29, no. 1 (2002): 7-29.

Callahan, Mary P. "Burma: Soldiers as State Builders." In Coercion and Governance: The Declining Political Role of the Military in Asia, edited by Muthiah Alagappa, 413-432. Stanford: Stanford University Press, 2001.

Carnegie, Paul J. "Latent Insurgency: Is the Threat of Militant Islamist Groups in Indonesia Diminishing?" In Insurgency and Counterinsurgency in Modern War, edited by Scott Nicholas Romaniuk and Stewart Tristan Webb, 127-134. Boca Raton: CRC Press, 2015.

Chen, Kai. "Book Review: Mietzner, M (ed.) (2013). The Political Resurgence of the Military in Southeast Asia: Conflict and Leadership." Austrian Journal of South-East Asian Studies 7, no. 1: 137-139.

Clausewitz, Carl von. On War. Translated by Michael Howard and Peter Paret. Princeton: Princeton University Press, 1976.

Cockett, Richard. Blood, Dreams and Gold: The Changing Face of Burma. Padstow: TJ International, 2015.

Collins, General A.S., Jr, USA (Ret.). “...On Land.” Bulletin of the Atomic Scientists 35, no. 5 (1979): 28-33.

Conboy, Kenneth. South-East Asian Special Forces. Oxford: Osprey Publishing, 1991.

Cook, Alistair C. B. "Human Insecurity and Displacement along Myanmar's Border." In Irregular Migration and Human Security in East Asia, edited by Jiyoung Song and Alistair C. B. Cook. 68-83. Abingdon: Routledge, 2015. 
Cooper, Andrew Scott. The Oil Kings: How the U.S., Iran, and Saudi Arabia Changed the Balance of Power in the Middle East. New York: Simon \& Schuster, 2011.

Croissant, Aurel, David Kuehn and Phillip Lorenz. Palgrave Macmillan Democratization and Civilian Control in Asia. Houndmills: Palgrave Macmillan, 2013.

Crouch, Harold. Political Reform in Indonesia after Soeharto. Singapore: Institute of Southeast Asian Studies, 2010.

Crouch, Harold. The Army and Politics in Indonesia. Singapore: Equinox Publishing, 2007.

Davies, Ed and Olivia Rondonuwu. "U.S-Funded Detachment 88, Elite of Indonesia Security." Reuters, March 18, 2010. Accessed September 27, 2015. www.reuters.com/article/2010/03/18/us-indonesia-usa-security-idUSTRE62H13F20100318.

Davis, Diane E. and Anthony W. Pereira, eds. Irregular Armed Forces and their Role in Politics and State Formation. New York: Cambridge University Press, 2003.

Desch, Michael C. Civilian Control of the Military: The Changing Security Environment. Baltimore: The John Hopkins University Press, 1999.

Diamond, Larry and Marc F. Plattner, eds. Civil-Military Relations and Democracy. Baltimore: The John Hopkins University Press, 1996.

Egreteau, Renaud. "Myanmar: Transition, Praetorian Politics, and the Prospects for Democratic Change." In Routledge Handbook of Southeast Asian Democratization, edited by William Case, 410-425. Abingdon: Routledge, 2015

Egreteau, Renaud. "Retired Military Officers in Myanmar's Parliament: An Emerging Legislative Force?" Trends in Southeast Asian Studies, no. 17, 2015, Singapore: Institute of Southeast Asian Studies.

Environmental Investigation Agency, Organised Chaos: The Illicit Overland Timber Trade between Myanmar and China. London: Environmental Investigation Agency, September 2015.

Feaver, Peter D. Armed Servants: Agency, Oversight, and Civil-Military Relations. Cambridge: Harvard University Press, 2003.

Fisher, Jonah. "Thein Sein: Myanmar Army to Continue Key Transition Role." BBC, March 20, 2015. Accessed April 27, 2015. http://www.bbc.com/news/world-asia-31957685.

Foreign Affairs, "Opening Indonesia: A Conversation with Joko Widodo." November/December, 2014, 56-61.

Foss, Christopher F. "Indonesia Expands Anoa Direct-fire Wheeled Vehicle Family." Jane's International Defence Review, January, 2015.

Fullilove, Michael, Andrew Selth and Sean Turnell. "Burma's Transition: Progress and Prospects." Lowy Institute for International Policy, Lowy Lecture Series, May 8, 2013. Accessed October 19, 2015. www.vimeo.com/65777907.

Gibson, Christopher P. Securing the State: Reforming the National Security Decision-Making Process at the Civil-Military Nexus. Aldershot: Ashgate Publishing, 2008. 
Goodpaster, Andrew P. and Samuel P. Huntington. Civil-Military Relations. Omaha: American Enterprise Institute for Public Policy Research, 1977.

Green, Michael. "Indonesia's Armed Force in the Democratic Era." Centre for Strategic Studies New Zealand, CSS Strategic Briefing Papers, Vol. 6, Part 1. November, 2011.

Hamid, Sandra. "Indonesian Politics in 2012: Coalitions, Accountability and the Future of Democracy." Bulletin of Indonesian Economic Studies 48, no. 3, (2012): 325-345.

Hoadley, Stephen J. The Military in the Politics of Southeast Asia: A Comparative Perspective. Cambridge: Schenkman Publishing Company, 1975.

Homan, Kees. "Civilian Control of the Military." In Promoting Good Governance in the Security Sector: Principles and Challenges, edited by Mert Kayhen and Merijn, 83-94. Groningen: Centre for European Security Studies, 2013.

Honna, Jun. Military Politics and Democracy in Indonesia. New York: Routledge, 2003.

Human Rights Watch. Unkept Promise: Failure to End Military Business Activity in Indonesia. New York: HRW, 2010.

Human Rights Watch. Vote to Nowhere: The May 2008 Constitutional Referendum in Burma. New York: HRW, 2008.

Hunter, Helen-Louise. Sukarno and the Indonesian Coup: The Untold Story. Westport: Prager Security International, 2007.

Huntington, Samuel P. The Soldier and the State: The Theory and Politics of Civil-Military Relations. London: Oxford University Press, 1959.

Huntington, Samuel P. The Third Wave: Democratization in the Late Twentieth Century. Norman: University of Oklahoma Press, 1993.

Ichihara, Maiko. "East Asia's Challenges to and Changes in the Peace Operations in East Timor." In Human Security in East Asia: Challenges for Collaborative Action, edited by Sorpong Peou, 94-107. Abingdon: Routledge, 2009.

Institute for Policy Analysis of Conflict. "The Expanding Role of the Indonesian Military." IPAC Report no. 19, May 25, 2015.

International Crisis Group. "Myanmar's Military: Back to Barracks?" Update Briefing, Asia Briefing no. 143, April 22, 2014.

International Human Rights Clinic (Harvard University). Policy Memorandum: Preventing Indiscriminate Attacks and Wilful Killings of Civilians by the Myanmar Military. Cambridge: Harvard University, 2014.

Jakarta Post, "Moeldoko Boasts of Feats During Tenure." July 8, 2015.

Jakarta Post, "Sutiyoso ready to lead BIN." June 10, 2015.

Jakarta Post. "TNI Blasted for not Handing over Businesses." March 12, 2011.

Janowitz, Morris, ed. Civil-Military Relations: Regional Perspectives. London: Sage, 1981. 
Janowitz, Morris. The Professional Soldier: A Social and Political Portrait. Glencoe: The Free Press of Glencoe, 1960.

Jenkins, David. Suharto and His Generals: Indonesian Military Politics 1975-1983.

Monograph Series Publication no. 64, $2^{\text {nd }}$ ed., New York: Cornell Modern Indonesia Project, 1987.

Jones, Lee. Societies under Siege: Exploring How International Economic Sanctions (Do Not) Work. Oxford: Oxford University Press, 2015.

Karmini, Niniek. "Victims of Aceh Conflict Await Justice in Indonesia." Irrawaddy, April 19, 2013. Accessed October 10, 2015. www.irrawaddy.org/asia/victims-of-aceh-conflict-awaitjustice-in-indonesia.html.

Kaspar, Andrew D. "Report Says Tatmadaw's Targeting of Civilians 'Ongoing' Urges Reforms." Irrawaddy, March 24, 2014. Accessed October 18, 2015.

www.irrawaddy.org/burma/report-says-tatmadaws-targeting-of-civilians-ongoing-ugesreforms.html.

Kent, Lia. The Dynamics of Transitional Justice: International Models and Local Realities in East Timor. Abingdon: Routledge, 2012.

Kesselman, Mark, Joel Krieger and William A. Joseph. Introduction to Comparative Politics: Brief Edition. Boston: Houghton Mifflin Harcourt, 2009.

Kilcullen, David. "Two School of Classical Counterinsurgency." Small Wars Journal, January 27, 2007. Accessed October 18, 2015, www.smallwarsjournal.com/blog/two-schools-ofclassical-counterinsgency.

Kilcullen, David. Counterinsurgency. London: Oxford University Press, 2010.

Kingsbury, Damien. Power Politics and the Indonesian Military. New York: Routledge, 2003.

Kingsbury, Damien. South-East Asia: A Political Profile. London: Oxford University Press, 2005.

Lee, Bong. The Unfinished War: Korea. New York: Algora Publishing, 2013.

Lee, Terence. "Democratization and the Political Role of the Armed Forces." World Peace Foundation: Tuffs University. Accessed October 13, 2015.

http://sites.tufts.edu/reinventingpeace/2014/10/15/democratization-and-the-political-role-ofthe-armed-forces/.

Leifer, Michael. Indonesia's Foreign Policy. London: George Allen and Unwin, 1983.

Lim, Chong-Yah. Southeast Asia: The Long Road Ahead. Singapore: World Scientific Publishing, 2004.

Lissak, Moshe. Military Roles in Modernization: Civil-Military Relations in Thailand and Burma. London: Sage, 1976.

Lowry, Bob. "Jokowi-to be or not to Bopbbe?" Australian Strategic Policy Institute, February 10, 2015. Accessed September 27, 2015. www.aspistrategist.org.au/jokowi-to-be-or-not-tobe/. 
Mang, Lin Min and Ye Mon. "As Ceasefire Signed, President Confident more Groups will join Nationwide Pact." Myanmar Times, October 15, 2015. Accessed October 20, 2015.

www.mmtimes.com/index.php/national-news/17020-president-says-confident-more-armedgroups-will-join-nationwide-ceasefire.html.

Mapes, Timothy, Jeremy Wagstaff and Rin Hindrayati. "Bomb in Jakarta Kills Nine Outside Australian Embassy." Wall Street Journal, September 10, 2004. Accessed October 5, 2015. www.wsj.com/articles/SB109470585484313350.

Marston, Hunter and Andrew Morgan. "Have Myanmar's Armed Forces Gone too Far?" Diplomat, April 8, 2015. Accessed October 23, 2015. www.thediplomat.com/2015/04/havemyanmars-armed-forces-gone-too-far/.

Maryanov, Gerald Seymour. Decentralization in Indonesia as a Political Problem. Singapore: Equinox, 2009.

Maslow, Abraham H. Psychology of Science: A Reconnaissance. Oxford: Gateway Editions, 1966.

Matthews, Bruce. "The Legacy of Tradition and Authority: Buddhism and the Nation of Myanmar." In Buddhism and Politics in Twentieth Century Asia, edited by lan Harris, 26-53. London: Continuum, 1999.

Maynard, Harold W. "The Role of the Indonesian Armed Forces." In The Political Influence of the Military: A Comparative Reader, edited by Amos Perlmutter and Valerie Plave Bennett, 186-213. New Haven: Yale University Press, 1980.

McCartan, Brian. "Myanmar Military in the Money." Asia Times, February 28, 2012. Accessed October 20, 2015. www.atimes.com/atimes/Southeast Asia/NB28Ae02.html.

McLeod, Andrew. "Aung San Suu Kyi Still in Running or Myanmar Presidency." BBC World News, July 10, 2015. Accessed October 18, 2015. www.bbc.com/news/world-asia33476250 .

Mendee, Jargalsaikhan. "Civil-Military Relations in a Dictatorship: North Korea." In The Routledge Handbook of Civil-Military Relations, edited by Thomas C. Bruneau and Florina Cristiana Matei, 79-92. New York: Routledge, 2013.

Mietzner, Marcus and Lisa Misol. "Military Businesses in post-Suharto Indonesia: Decline, Reform and Persistence." In The Politics of Military Reform: Experiences from Indonesia and Nigeria, edited by Jürgen Rüland, Maria-Gabriela Manea and Hans Born, 101-122.

Heidelberg: Springer, 2013.

Mietzner, Marcus. Military Politics, Islam, and the State of Indonesia: From Turbulent Transition to Democratic Consolidation. Singapore: Institute of Southeast Asian Studies, 2009.

Mietzner, Marcus. The Political Resurgence of the Military in Southeast Asia. Abingdon: Routledge, 2011.

Mietzner, Marcus. The Politics of Military Reform in Post-Suharto Indonesia: Elite Conflict, Nationalism, and Institutional Resistance. Washington D.C: East-West Centre, 2006.

Min, Colonel (Rtd.) Hla. The Way I See It: Myanmar and its Evolving Global Role. Yangon: Zin Yadanar Saw Publishing House, 2013. 
Min, Win. "Internal Dynamics of the Burmese Military: Before, during and after the 2007 Demonstrations." In Dictatorship, Disorder and Decline in Myanmar, edited by Monique Skidmore and Trevor Wilson, 29-47. Canberra: Australian National University, 2008.

Ministry of Defence (Indonesia). 2003 Indonesian Defence White Paper: Defending the Country in the $21^{\text {st }}$ Century. Jakarta: Ministry of Defence, 2003.

Montessoro, Franceso. Reform and Modernization of the Indonesian Forces, Analysis No. 268. Milan: Italian Institute for International Political Studies, 2014.

Myanmar Government. Constitution of the Republic of the Union of Myanmar. Naypyidaw, Printing and Publishing Enterprise - Ministry of Information, 2008.

Myoe, Maung Aung. "The Military and Political Liberalisation in Myanmar." In Myanmar in Transition: Polity, People and Processes, edited by Kerstin Duel, 57-66. Singapore: KonradAdenauer Stiftung, 2013.

Myoe, Maung Aung. Building the Tatmadaw: Myanmar Armed Forces Since 1948. Singapore: ISEAS, 2009.

Narine, Shaun. Explaining ASEAN: Regionalism in Southeast Asia. Boulder: Lynne Rienner, 2002.

Nazeer, Zubaidah. “Indonesia's President Jokowi drops Budi Gunawan as Police Chief Nominee." Straits Times, February 18, 2015. Accessed October 3, 2015. www.staritstimes.com/asia/se-asia/indonesias-president-jokowi-drops-budi-gunawan-aspolice-chief-nominee.

Nicholas Farrelly. "NLD needs to Lift the Standard." New Mandala, September 21, 2015, accessed October 18, 2015, www.asiapacific.anu.edu.au/newmandala/2015/09/23/nldneeds-to-lift-the-standard/.

North Atlantic Treaty Organisation. Allied Joint Publication 9: NATO Civil-Military Cooperation Doctrine. Brussels: North Atlantic Treaty Organisation, 2003.

$\mathrm{Nu}$, Than Than. "From Exile to Elections." In Debating Democratization in Myanmar, edited by Nick Cheesman, Nicholas Farrelly and Trevor Wilson, 93-108. Singapore: Institute of Southeast Asian Studies, 2014.

Nyein, Susanne Prager. "The Armed Forces of Burma." In The Political Resurgence of the Military in Southeast Asia: Conflict and Leadership, edited by Marcus Mietzner, 24-44. Abingdon: Routledge, 2011.

Nyman, Mikaela. Democratising Indonesia: The Challenges of Civil Society in the Era of Reformasi. Copenhagen: Nordic Institute of Asian Studies, 2006.

Olsen, Edward A. and Jurika, Stephen Jr. The Armed Forces in Contemporary Asian Societies. Boulder: Westview Press, 1986.

Organisation for Economic Co-operation and Development (OECD). OECD Development Pathways: Multi-dimensional Review of Myanmar - Volume 2: In-Depth Analysis and Recommendations. Paris: OECD Publishing, 2014. 
Perlmutter, Amos and Bennett, Valerie Plave, eds. The Political Influence of the Military: A Comparative Reader. New Haven: Yale University, 1980.

Pinto, Constancio and Matthew Jardine. Inside the East Timor Resistance. Toronto: James Lorimer and Company, 1997.

Pisani, Elizabeth. Indonesia Etc: Exploring the Improbable Nation. New York: W. W. Norton and Company, 2014.

Poveter, David Henry. "Myanmar's Roadmap Comes Full Circle." Asia Times, September 14, 2011. Accessed October 18, 2015. www.atimes.com/atimes/Southeast Asia/Ml14Ae01.html.

Provizer, Norman W., ed. Analysing the Third World: Essays on Comparative Politics. Cambridge: Schenkman Publishing Company, 1978.

Rabasa, Angel and John Haseman. The Military and Democracy in Indonesia: Challenges, Politics and Power. Santa Monica: RAND, 2002.

Reilly, Benjamin. Democracy and Diversity: Political Engineering in the Asia-Pacific. London: Oxford University Press, 2006.

Renton-Green, Andrew. "Indonesia after Soeharto: Civil or Military Rule." Centre for Strategic Studies: New Zealand, Working Paper No. 12, 1998. Accessed March 10, 2015. http://www.victoria.ac.nz/hppi/centres/strategic-studies/publications/workingpapers/WP12.pdf.

Richard Robinson. Indonesia: The Rise of Capital. Singapore: Equinox, 2009.

Rieffel, Lex and Jaleswari Pramodhawardani. Out of Business and on Budget: The Challenge of Military Financing in Indonesia. Washington DC: Brookings, 2007.

Rinakit, Sukardi. The Indonesian Military After the New Order. Copenhagen: Nordic Institute of Asian Studies, 2005.

Robertson-Snape, Fiona. "Corruption, Collusion and Nepotism in Indonesia." Third World Quarterly 20, no.3, (1999): 589-602.

Robson, Sarah. "Trade on John Key's Mind in Myanmar." 3 News, November 13, 2014. Accessed October 18, 2015. www.3news.co.nz/nznews/trade-on-john-keys-mind-inmyanmar-2014111306\#axzz3pBH2Eiae.

Rolfe, Jim and Andrew Butcher. Indonesia: Continuing the Move to a Fully Functioning Democracy, Strategic Background Paper 19/2014. Wellington: Centre for Strategic Studies: New Zealand, 2014. Accessed February 3, 2015.

http://www.victoria.ac.nz/hppi/centres/strategicstudies/documents/19 Indonesia Continuing-the-move-to-Democracy.pdf.

Sebastian, Leonard and lisgindarsah. "Taking Stock of Military Reform in Indonesia." In The Politics of Military Reform: Experiences from Indonesia and Nigeria, edited by Jürgen Rüland, Maria-Gabriela Manea and Hans Born, 29-56. Heidelberg: Springer, 2013.

Sebastian, Leonard C. Realpolitik Ideology: Indonesia's Use of Military Power. Singapore: Institute of Southeast Asian Studies, 2006. 
Selth, Andrew. "Burma: Beware of Unrealistic Expectations." Lowy Interpreter, June 18, 2015. Accessed October 29, 2015. www.lowyinterpreter.org/author/Andrew\%Selth.aspx.

Selth, Andrew. Burma's Armed Forces: Power Without Glory. Norwalk: East Bridge, 2002.

Selth, Andrew. Transforming the Tatmadaw: the Burmese Armed Forces Since 1988, Canberra Papers on Strategy and Defence, No 113. Canberra: Australian National University, 1996.

Singh, Belveer. Civil Military Relations in Democratising Indonesia: The Potentials and Limits to Change. Canberra Papers on Strategy and Defence No. 141. Canberra: Australian National University, 2001.

Singh, Belveer. Dwifungi ABRI: The Dual Function of the Indonesian Armed Forces: Origins, Actualization and Implications for Stability and Development. Singapore: Singapore Institute of International Relations, 1995.

Singh, Bilveer. "Religion as a Political ideology in Southeast Asia." In The Politics of Religion in South and Southeast Asia, edited by Ishtiaq Ahmed, 120-135. Abingdon: Routledge, 2011.

Smith, Anthony L. "Indonesia: Transforming the Leviathan." In Government and Politics in Southeast Asia, edited by John Funston, 74-119. Singapore: Institute of Southeast Asian Studies, 2001.

Sukma, Rizal. "The Role of Civil Society in Indonesia's Military Reform." In The Politics of Military Reform: Experiences from Indonesia and Nigeria, edited by Jürgen Rüland, MariaGabriela Manea and Hans Born, 147-160. Heidelberg: Springer, 2013.

Sun Tzu. The Art of War. Translated by Samuel B. Griffith. London: Duncan Baird Publishers, 2005.

Taylor, Charles W. "Projecting the Changing Conflict Setting." In Special Operations Forces: Roles and Missions in the Aftermath of the Cold War, edited by Richard H. Schultz, Jr., Robert L. Pfaltzgraff, Jr., W. Bradley Stock, 45-58. Collingdale: Diane Publishing, 1995.

Taylor, Charles W.. Creating Strategic Visions. Carlisle: Strategic Studies Institute, U.S. Army War College, 1990.

Taylor, Robert H. General Ne Win: A Political Biography. Singapore: Institute for Southeast Asian Studies, 2015.

Tha, Kyaw Phyo. "US Too Optimistic about Burma Reform: Suu Kyi." Irrawaddy, November 5, 2014. Accessed October 12, 2015. www.irrawaddy.org/burma/us-optimistic-burma-reformsuu-kyi.html.

Than, Tin Maung Maung. "Ethnic Insurgencies and Peacemaking in Myanmar." In ISEAS Perspectives: Selections 2012-2013, edited by Ooi Kee Beng, 103-115. Singapore: Institute of Southeast Asian Studies, 2014.

The Report: Indonesia 2012. London: Oxford Business Group, 2012.

Topich, William J. and Keith A. Leitich. The History of Myanmar. Santa Barbara: Greenwood, 2013. 
Vatikotis, Michael R. J. Indonesia Politics under Suharto: The Rise and Fall of the New Order. London: Routledge, 1993.

Wilson, Trevor. "The Significance of Myanmar's 2010 Election." New Mandala, December 15, 2010. Accessed October 18, 2015.

www.asiapacific.anu.edu.au/newmandala/2010/12/15/the-significance-ofmyanmar\%E2\%80\%99s-2010-election/.

Woo, Jongseok Security. Challenges and Military Politics in East Asia: Form State Building to Post-Democratisation. London: Continuum International, 2011.

Yawnghwe, Chao-Tzang. "Burma: The Depoliticization of the Political." In Political Legitimacy in Southeast Asia: The Quest for Moral Authority, edited by Muthiah Alagappa, 170-192. Stanford: Stanford University Press, 1995.

Zaw, Hnin Yadana. "Myanmar Military Retains Veto after Opposition Change Vote Fails." Reuters, June 25, 2015. Accessed October 19, 2015. www.yahoo.com/myanmar-parlimentvoting-amending-key-parts-of-consitiution-074822297.html.

Zaw, John. "Myanmar's Army Releases 51 Child Soldiers." UCA News, June 5, 2015.

Accessed October 22, 2015. http://www.ucanews.com/news/myanmars-army-releases-51child-soldiers/73734.

Zin, Min. "Is Burma's Opposition Ready for the Post-Aung San Suu Kyi Era?" Foreign Policy, August 18, 2015. Accessed October 18, 2015. www.foreignpolicy.com/2015/08/18/isburmas-opposition-ready-for-the-post-aung-san-suu-kyi-election/. 


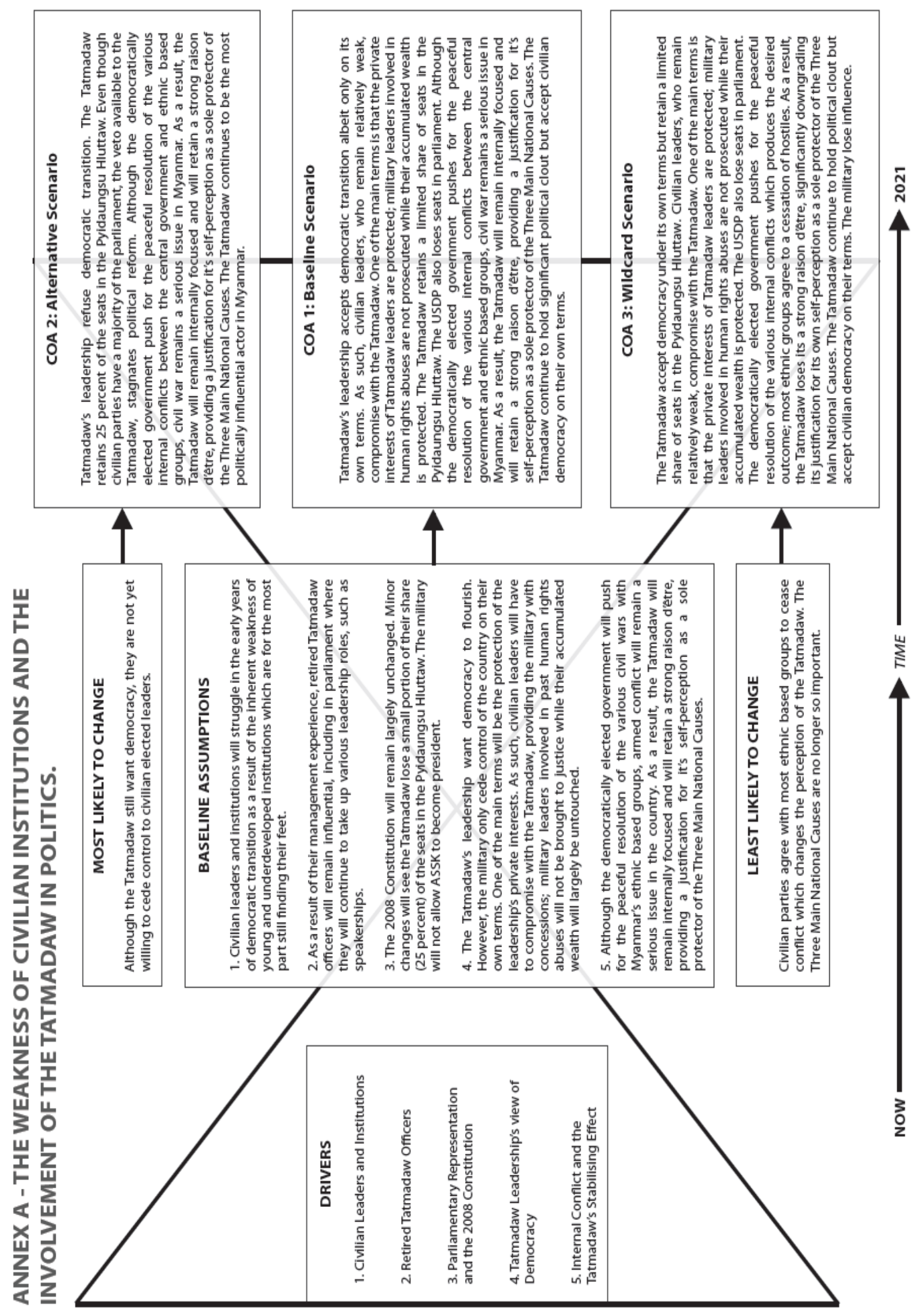




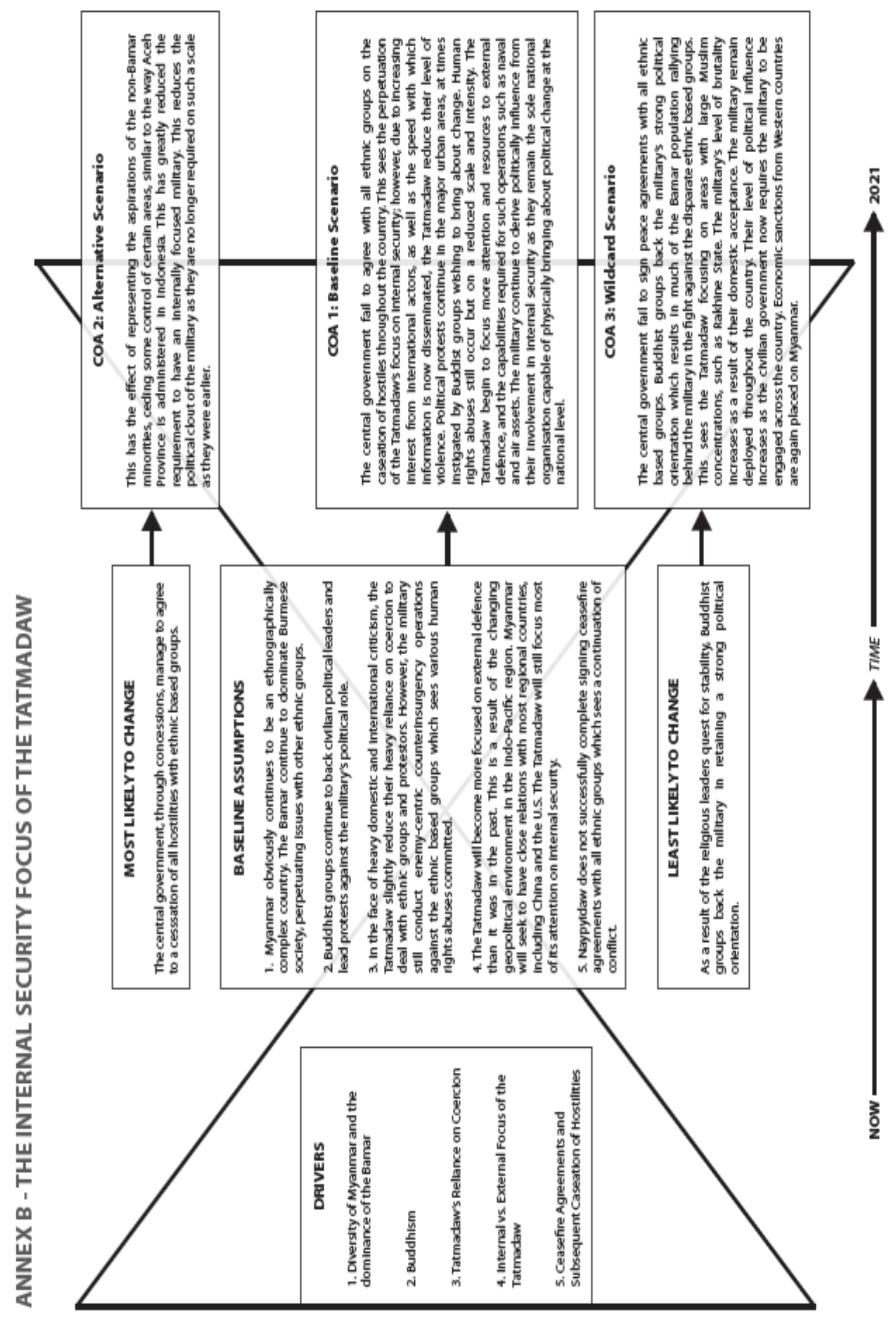




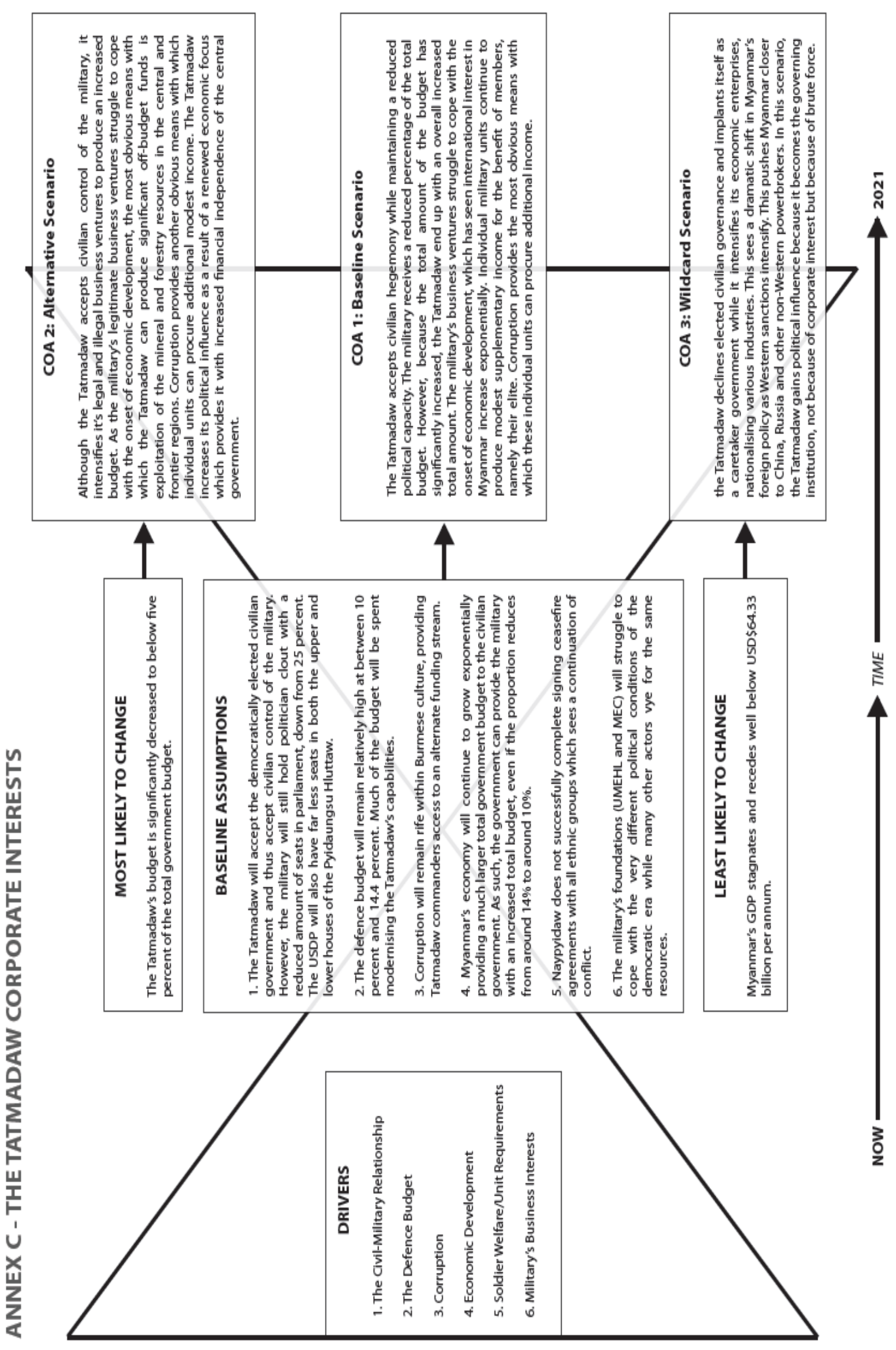

